\title{
pH-dependent control of feldspar dissolution rate by altered surface layers
}

\section{Revision 1}

Bastien Wild ${ }^{\mathrm{a}, *}$, Damien Daval ${ }^{\mathrm{a}}$, François Guyot ${ }^{\mathrm{b}}$, Kevin G. Knauss ${ }^{\mathrm{c}}$, Marion Pollet-Villard ${ }^{\mathrm{a}}$, Gwenaël Imfeld $^{\mathrm{a}}$

${ }^{\text {a }}$ Laboratoire d'Hydrologie et de Géochimie de Strasbourg (LHyGeS), Université de Strasbourg /EOST-CNRS UMR 7517, 1 Rue Blessig, 67000 Strasbourg, France

${ }^{\mathrm{b}}$ Institut de Minéralogie, de Physique des Matériaux et de Cosmochimie (IMPMC), Sorbonne Universités - CNRS UMR 7590, Muséum National d'Histoire Naturelle, UPMC, 61 rue Buffon, 75005 Paris, France

${ }^{\mathrm{c}}$ Earth Sciences Division, Lawrence Berkeley National Laboratory, Berkeley, CA 94720, USA

*corresponding author: bastien.wild@unistra.fr (B.Wild) 


\section{ABSTRACT}

Relevant modeling of mass and energy fluxes involved in pedogenesis, sequestration of atmospheric $\mathrm{CO}_{2}$ or geochemical cycling of elements partly relies on kinetic rate laws of mineral dissolution obtained in the laboratory. Deriving an accurate and unified description of mineral dissolution has therefore become a prerequisite of crucial importance. However, the impact of amorphous silica-rich surface layers on the dissolution kinetics of silicate minerals remains poorly understood, and ignored in most reactive transport codes. In the present study, the dissolution of oriented cleavage surfaces and powders of labradorite feldspar was investigated as a function of $\mathrm{pH}$ and time at $80^{\circ} \mathrm{C}$ in batch reactors. Electron microscopy observations confirmed the formation of silica-rich surface layers on all samples. At $\mathrm{pH} 1.5$, the dissolution rate of labradorite remained constant over time. In contrast, at $\mathrm{pH} 3$, both the dissolution rates at the external layer/solution interface and the internal layer/mineral interface dramatically decreased over time. The dissolution rate at the external interface was hardly measurable after 4 weeks of reaction, and decreased by an order of magnitude at the internal interface. In another set of experiments conducted in aqueous silica-rich solutions, the stabilization of silica-rich surface layers controlled the dissolution rate of labradorite at $\mathrm{pH} 3$. The reduction of labradorite dissolution rate may result from a gradual modification of the textural properties of the amorphous surface layer at the fluid-mineral interface. The passivation of the main cleavage of labradorite feldspar was consistent with that observed on powders. Overall, our results demonstrate that the nature of the fluid/mineral interface to be considered in the rate limiting step of the process, as well as the properties of the interfacial layer (i.e. its chemical composition, structure and texture) to be taken into account for an accurate determination of the dissolution kinetics may depend on several parameters, such as $\mathrm{pH}$ or time. The dramatic impact of the stabilization of surface layers with increasing $\mathrm{pH}$ implies that the formation and the role of surface layers on dissolving feldspar minerals should be accounted for in the future. 


\section{Keywords:}

feldspar; ageing; surface layer; passivation; weathering; dissolution rates 


\section{INTRODUCTION}

The critical zone in the Earth's near surface sustains several processes and ecosystem services such as soil formation (Godderis et al., 2010), $\mathrm{CO}_{2}$ uptake due to silicate weathering (Beaulieu et al., 2012) and the biogeochemical cycling of elements (Olsson et al., 1996; White et al., 2012). Understanding these processes requires the quantification of elemental fluxes through the critical zone and the contribution of chemical weathering of minerals. Current approaches to estimate dissolution rates under field conditions often rely on kinetic rate laws determined under laboratory conditions. Despite extensive investigations over the last decades, rates measured in laboratory setups can still differ by up to 6 orders of magnitude compared to those observed in the field (e.g. Zhu, 2005). The origin of this “laboratory-field discrepancy” still remains unclear (White and Brantley, 2003).

Several factors may explain this discrepancy, which can be sorted into extrinsic and intrinsic factors. Extrinsic factors involve the surrounding of the mineral, encompassing the reacting fluid composition and environmental parameters in general. Intrinsic factors are related to the mineral itself, its chemical composition and structure, and to the presence of surface layers or other interfacial properties. An increasing number of laboratory studies and field observations regarding the role of intrinsic factors challenge the classical concepts relying on the homogeneity and immutability of the reacting solid phase. For instance, mineral reactivity may exhibit spatial heterogeneities when interacting with a reactive fluid (Fischer et al., 2012; Fischer et al., 2014), and the nature of the rate-controlling phase itself may evolve or even change during the reaction (Daval et al., 2011). This latter result strengthens the conclusions drawn from field studies which suggest that mineral reactivity may evolve with time (Maher et al., 2004; Fantle and DePaolo, 2006; Porder et al., 2007). In particular, fluid-mineral interactions may be controlled by interfacial features, such as amorphous Si-rich surface layers (ASSL) (Wang and Giammar, 2013). ASSLs have been 
identified in a wide variety of natural environments and mineral substrates (Kawano and Tomita, 2001; Zhu et al., 2006; Hellmann et al., 2012), indicating their ubiquity. ASSLs were brought to the forefront of mineral reactivity by Hellmann et al. (2003), and identified as a first-order rate parameter in laboratory experiments where silicate dissolution rates dramatically drop in solutions close to amorphous silica saturation (Daux et al., 1997; Daval et al., 2011; Daval et al., 2013; Johnson et al., 2014; Maher et al., 2016).

Despite recent efforts to decipher the impact of interfacial features on dissolution rates, the dissolution mechanisms of feldspar minerals still lack consensual agreement. Indeed, early studies suggested that a diffusive control of the dissolution rate by a Si-rich surface layer located at the fluid-mineral boundary caused the parabolic cation release observed during feldspar dissolution (Correns and von Engelhardt, 1938; Wollast, 1967; Helgeson, 1971). However, the scattering of data obtained on analogous experimental setups that could not be explained solely by diffusive process (Lagache, 1976), or experimental artefacts arising from ultrafine particles within the starting material (Holdren and Berner, 1979) contradicted the surface layer hypothesis. The parabolic cation release was then explained by the preferential dissolution of higher reactivity sites, despite subsequent improvements designed to overcome the weaknesses of original protocols (Knauss and Wolery, 1986; Carroll and Knauss, 2005). Recent studies have led to the consensus that surface layers are formed at the interface between the reacted feldspar and the reacting fluid (Hellmann et al., 1990; Gout et al., 1997; Hellmann et al., 2003; Hellmann, 2004; Hellmann et al., 2012). Although several studies have focused on the mechanism of surface layer formation, knowledge of their impact on dissolution rates remains incomplete.

This study aims to evaluate how surface layers formed on labradorite affect the dissolution rates at $80^{\circ} \mathrm{C}$. Reacting materials consisted either of labradorite powder or of oriented surfaces of labradorite single crystals, the latter being used to evaluate whether the crystallographic 
orientation influences the dissolution rate and the rate-controlling mechanisms of labradorite dissolution. Aqueous fluids of $\mathrm{HCl}$ solutions of $\mathrm{pH}=1.5,2,2.5$ and 3, which corresponds to the highest $\mathrm{pH}$ value for which experiments are not impacted by secondary phases, were used to collect $\mathrm{pH}$-resolved data. For some modalities, reacting fluids were saturated with respect to amorphous silica to constrain the impact of surface layers on the dissolution rates. Overall, our results emphasize that the formation of surface layers can affect the dissolution kinetics of labradorite. The $\mathrm{pH}$ of the reacting fluid controls the textural properties of the layers, with increasing passivation effect at higher $\mathrm{pH}$.

\section{MATERIALS AND METHODS}

\subsection{Sample preparation}

Centimeter-sized labradorite single crystals from Madagascar were purchased from Mawingu Gems. They consist of translucent greyish cm-sized euhedral to anhedral crystals containing Fe-rich inclusions. The chemical composition of the samples $\left(\mathrm{Na}_{0.45}\right.$ $\mathrm{K}_{0.02} \mathrm{Ca}_{0.52} \mathrm{Al}_{1.49} \mathrm{Si}_{2.49} \mathrm{O}_{8}$ ) was determined by electron microprobe.

A first part of the samples was used to prepare oriented surfaces. Labradorite samples were oriented along (001) and (010) preferential cleavages, and cut following selected crystallographic orientations. Oriented samples were then embedded in epoxy resin and polished through a multi-step abrasive sequence with an ultimate polishing step in a colloidal silica suspension. The crystallographic orientations were verified over the whole surface using electron backscatter diffraction (EBSD) on a Tescan Vega 2 scanning electron microscope (SEM). The initial roughness of labradorite surfaces was estimated using a Digital Instruments atomic force microscope (AFM), and a Zygo New View 7300 vertical scanning interferometer (VSI). Roughness parameters given in the present work refer to the root mean squared roughness, calculated over each entire measured area: 


$$
R_{a}=\frac{1}{n} \sum_{i=1}^{n}\left|Z_{i}-\bar{Z}\right|
$$

and to the average roughness:

$$
R_{q}=\sqrt{\frac{1}{n} \sum_{i=1}^{n}\left(Z_{i}-\bar{Z}\right)^{2}}
$$

where $i$ stands for the index referring to each of the $n$ data points of the considered array, $Z_{i}$ to its height and $\bar{Z}$ to the mean height calculated over the considered array. Measurements yield typical values of $1 \mathrm{~nm} \leq R a \leq 18 \mathrm{~nm}, 1 \mathrm{~nm} \leq R q \leq 20 \mathrm{~nm}$, on $5 \times 5$ to $80 \times 80 \mu \mathrm{m}^{2}$ AFM images and $3 \mathrm{~nm} \leq R a \leq 21 \mathrm{~nm}, 4 \mathrm{~nm} \leq R q \leq 36 \mathrm{~nm}$, on $500 \times 500 \mu \mathrm{m}^{2}$ VSI images. The geometric surface area of labradorite surfaces was determined by image analysis with the ImageJ software (Abramoff, 2004; Schneider et al., 2012) using binocular photographs of each sample. The sample surfaces were subsequently cleaned with ethanol and air dried. Several portions of the surface were protected with $\sim 1 \mathrm{~mm}^{2} \mathrm{RTV}$ glue spots, referred to as "glue masks" hereafter (see section 2.5). The chemical inertness of the masks with respect to the mineral surface as well as their stability were checked prior to the start of the experiments. Si release generated by a typical amount of 20 glue masks on an epoxy stud immersed for several days in $120 \mathrm{~mL}$ of $\mathrm{HCl}$ at $80^{\circ} \mathrm{C}$ (in situ $\mathrm{pH}=1.5$ ) was negligible.

Labradorite samples were also prepared as powders. Labradorite single crystals were washed with water, dried, crushed with a hydraulic press, sieved to recover the $160-315 \mu \mathrm{m}$ fraction and sonicated in ethanol to get rid of fine particles. The powder was then dried overnight at $35^{\circ} \mathrm{C}$. The specific surface area measured with 7-points $\mathrm{Kr}$ BET was $0.051 \mathrm{~m}^{2} \mathrm{~g}^{-1}$.

\subsection{Experimental protocol}

\subsubsection{Experimental setup}

Labradorite samples, either consisting of weighed amounts of powder or polished monoliths, were introduced into $120 \mathrm{~mL}$ PTFE Savillex® reactors continuously stirred with 
magnetic bars placed over PTFE tripods. The reactors were filled with $100 \mathrm{~mL}$ of reacting solutions and incubated at $80^{\circ} \mathrm{C}$.

\subsubsection{Experiments in aqueous Si-rich solutions}

Fluid saturation with respect to any solid material is defined as:

$$
S I=\log _{10}\left(\frac{Q\left(a_{\text {products }}\right)}{K(T)}\right)
$$

where $Q\left(a_{\text {products }}\right)$ stands for the reaction quotient and $K(T)$ for the temperature $(T)$-dependent equilibrium constant of the dissolution reaction. The experiments were conducted in both $\mathrm{SiO}_{2}(\mathrm{aq})$-rich and $\mathrm{SiO}_{2}(\mathrm{aq})$-low solutions. Reacting solutions were prepared from ultrapure

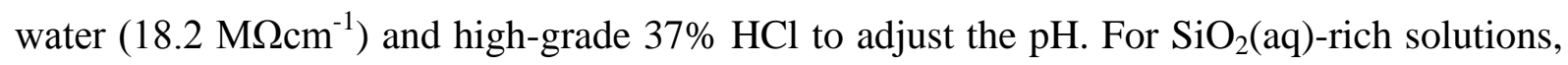
the fluid was saturated with respect to amorphous silica at $80^{\circ} \mathrm{C}(S I=0)$ by dissolving $1.48 \mathrm{~g}$ of sodium metasilicate, nonahydrate (Sigma Aldrich ${ }^{\circledR},>98 \%$ ) in $1 \mathrm{~kg}$ of solution. Total dissolution of sodium metasilicate was ensured by vigorous stirring, followed by a sonication step. pH was subsequently adjusted with hydrochloric acid (37\%, ACS reagent) and verified two days after the preparation of the solution.

\subsubsection{Face-specific experiments}

A series of experiments at a mid-range $\mathrm{pH}(\mathrm{pH}=2.5)$ was designed to tackle the influence of anisotropy on dissolution rates. It consisted of face-specific experiments, where (i) only the desired face was exposed to the reactive fluid, and (ii) each crystal orientation was reacted separately. This procedure enabled us to retrieve face-resolved fluid data and to determine the face specific dissolution rate at the boundary between the surface layer and the pristine mineral, defined hereafter as the "internal interface". The opposite boundary of the surface layer, located at the interface with the bulk solution is referred to as the "external interface". The dissolution rate at the external interface was determined on each orientation with the standard VSI protocol described in sections 2.5 and 2.6. Two faces identified as the 
main cleavages on euhedral monoliths were selected, corresponding to (001) and (010) planes. In addition, two other orientations that were not expressed at the macro scale, namely $(10 \overline{1})$ and (110) orientations were further studied. Additionally, batch powder experiments at $\mathrm{pH}=2$ and 2.5 were conducted to evaluate the representativeness of the selected faces.

\subsubsection{Sample recovery and fluid analysis}

The reactors were regularly sampled for $\mathrm{pH}$ measurements and chemical analyses. The fluid mass loss due to sampling and fluid evaporation was estimated by regularly weighing the reactors. The $\mathrm{Ca} / \mathrm{Si}$ ratios were calculated from inductively coupled plasma atomic emission spectroscopy (ICP-AES) data acquired with a Thermo ICAP 6000 Series apparatus as follows:

$$
C a / S i=\frac{\Delta C a}{\Delta S i}
$$

where $\triangle C a$ and $\triangle S i$ stand for the amount of $\mathrm{Ca}$ and $\mathrm{Si}$ released between two sample collections.

At the end of each experiment, the fluid was recovered and the solid samples were briefly rinsed with deionized MilliQ ${ }^{\circledR} \mathrm{H}_{2} \mathrm{O}$ and absolute ethanol (Sigma Aldrich ${ }^{\circledR}$, ACS reagent). The samples were then dried overnight at $35^{\circ} \mathrm{C}$. Glue masks were eventually pulled off with PTFE tweezers, and potential glue left-over was removed with a single-tip swab (Puritan®) impregnated with ethanol.

\subsection{Thermodynamic calculations}

The in situ $\mathrm{pH}$ and saturation indices for labradorite, amorphous silica and potential secondary phases at $80^{\circ} \mathrm{C}$ were calculated using the Chess ${ }^{\circledR}$ software (Van der Lee and De Windt, 2002) and the Chess ${ }^{\circledR}$ tdb database (Lawrence Livermore National Laboratories EQ3/6 database, $8^{\text {th }}$ version). Thermodynamic constants for labradorite dissolution were calculated from those for albite (Ab) and anorthite (An), supposing an ideal solid solution 
between albite and anorthite (see Testemale et al. (2009) for details) end-members, and equal proportions of albite and anorthite.

Activity coefficients for aqueous species were calculated with Chess ${ }^{\circledR}$ using the truncated Davies equation. Initial $\mathrm{pH}$ was calculated based on the initial weighed amount of $\mathrm{HCl}$ introduced into solution. From this starting point onwards, $\mathrm{pH}$ was used as an adjustable parameter to achieve charge balance.

For experiments saturated with respect to amorphous silica, the high background level for $\mathrm{Si}$ and $\mathrm{Na}$ resulting from the added sodium metasilicate powder precluded the accurate determination of $\mathrm{Si}$ and $\mathrm{Na}$ released from the mineral, which complicates the calculation of the saturation indices. For these experiments, the aqueous concentrations of $\mathrm{Si}$ and $\mathrm{Na}$ were estimated from the weighed amount of ultrapure MilliQ ${ }^{\circledR}$ water and chemical reagents in the initial solutions to which were added the estimated quantity of $\mathrm{Si}$ and $\mathrm{Na}$ released by the mineral dissolution based on $\mathrm{Ca}$ (when sufficiently accurate) or on $\mathrm{Al}$ concentrations, assuming a stoichiometric dissolution of labradorite:

$$
n_{X_{\text {estimated }}}(t)=n_{X_{\text {initial }}}+\left(\frac{\eta_{X}}{\eta_{Y}}\right) * n_{Y}(t)
$$

where $n_{X}$ stands for the estimated released amount of $\mathrm{Si}$ or $\mathrm{Na}$ due to mineral dissolution at $t$, $n_{Y}(t)$ is the total amount of calcium or aluminum released into solution at $t$ and $\eta_{i}$ is the stoichiometric coefficient of element $i$ in the bulk labradorite.

\subsection{Sample observation and determination of surface layer thickness}

Samples were either gold- or carbon-coated, and investigated with SEM and energy dispersive X-ray (EDX) spectroscopy. For samples exhibiting layer thickness exceeding 1 $\mu \mathrm{m}$, transects of reacted samples were cut perpendicularly to the reacted surface with a diamond saw across the masked area when possible and embedded in epoxy resin. This cross 
section was then polished, carbon-coated and the layer thickness was measured with SEM. For samples with layers thinner than $1 \mu \mathrm{m}$, ultrathin electron transparent cross sections were milled by focused ion beam (FIB) through the reacted surface, which was previously recoated with a thick carbon layer to prevent Pt and Ga ion beam damages to the sample (Lee et al., 2007). FIB thin sections were prepared following conventional procedures (Saldi et al., 2015), and analyzed by transmission electron microscopy (TEM) using a JEOL 2100F microscope operating at $200 \mathrm{kV}$, equipped with a field emission gun and an energy dispersive $\mathrm{X}$-ray analysis system from JEOL.

\subsection{Determination of surface retreat}

Sample topography was measured by VSI on each polished mineral sample prior to reaction. A portion of the surface was then masked with a RTV glue spot to avoid fluidmineral contact at this particular location. The masks were removed at the end of the experiments, and the sample topography was measured with VSI. The height difference between the reacted and the masked areas created by labradorite dissolution is referred to as surface retreat.

For samples which exhibited large surface retreats, the dissolution profiles were corrected from the starting topography using a three-step routine developed in Matlab® environment. Briefly, linear profiles were recorded across the masked area at the exact same location of the sample surface prior to and after reaction (Fig. 1A). Profiles were then superimposed on a common $x$ scale by linear interpolation:

$$
z(x)=z\left(x_{1}\right)+\frac{\left(z\left(x_{2}\right)-z\left(x_{1}\right)\right)}{\left(x_{2}-x_{1}\right)} *\left(x-x_{1}\right)
$$

where $z$ is the height at a given abscissa, $x$ is the projected distance from the common origin of both profiles to any recorded pixel in the post-reaction profile, and $x_{1}$ and $x_{2}$ correspond to the projected distances along the pre-reaction profile of the closest recorded pixels preceding 
and following $x$ respectively. The trend due to global tilt of the sample was then subtracted for both profiles by subtracting a linear fit performed on a common portion of surface area, i.e. belonging to the masked zone (see Fig. 1B), unaffected by the reaction. The obtained corrected profiles (Fig. 1C) were eventually subtracted one from another to obtain surface retreat along the $x$ coordinate (Fig. 1D). Final retreat value corresponds to the difference between the mean height of the masked area and the mean height of the unmasked area, while uncertainty integrates height variation on both portions.

As shown on Fig. 2A and B, small surface retreats $(<100 \mathrm{~nm})$ were locally measured in the direct vicinity of the boundary between the masked and the unmasked portions (typically $50 \mu \mathrm{m}$ each side). The mean surface retreat was estimated from the peak-to-peak distance measured between the reference and the retreated portions of the surface on the altitude distribution histogram (Fig. 2C). The uncertainty on surface retreat was estimated from their full width at half maximum. As shown on Fig. 2D, relevance of the selected altitudes on the histogram were checked for being consistent with retreats from linear profiles on the same zones to avoid artefacts resulting from residual scratches (Fig. 2D).

\subsection{Estimation of the dissolution rate}

Absolute dissolution rate at the external interface was estimated from the surface retreat following Arvidson et al. (2004):

$$
r=\frac{\Delta h}{\Delta t * V_{m}}
$$

where $r$ stands for the absolute dissolution rate in mol.m $\mathrm{m}^{-2} \cdot \mathrm{s}^{-1}, \Delta h$ is the surface retreat, $\Delta t$ is the alteration duration and $V_{m}$ is the molar volume of labradorite, in $\mathrm{m}^{3} \cdot \mathrm{mol}^{-1}$.

Rate at the internal interface was estimated on the basis of the release of elements from the mineral into the solution, and calculated as follows: 


$$
R(X)=\frac{\Delta X}{\Delta t * S * \eta_{X}}
$$

where $\Delta X$ and $\Delta t$ stand for the amount of element $\mathrm{X}$ released to the solution by the dissolution process and the elapsed time between two consecutive aqueous samples respectively, $S$ is the surface area of the mineral, and $\eta_{X}$ is the stoichiometric coefficient of element $X$ in the bulk labradorite. To avoid distortion due to the incorporation of element $X$ into secondary products, $\mathrm{Al}$ or $\mathrm{Ca}$ were preferentially and independently used as elemental tracers in most experiments to estimate the dissolution rates.

The surface term $S$ in equation 8 can either refer to the initial geometric surface area for macroscopic crystal samples or to the initial BET surface area for powders. This difference in the surface estimation precludes a direct comparison of the absolute rates between experiments run on powders or cleaved surfaces.

\subsection{Propagation of uncertainties}

Error bars for data based on measurements of cation release into solution were propagated from ICP-AES measurements. Elemental ratio uncertainties were estimated as:

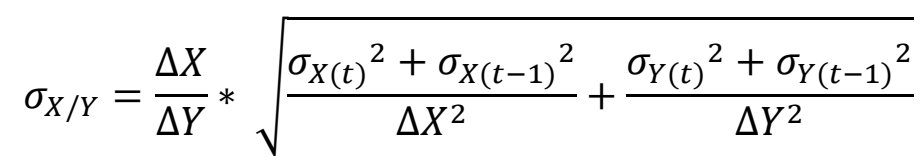

where $\Delta X$ and $\Delta Y$ stand for the amount of calcium and silicon released between two sample collections, while $\sigma_{X(t)}$ and $\sigma_{Y(t)}$ account for analytical errors on $\mathrm{X}$ concentration $(\mathrm{X})$ and $\mathrm{Y}$ concentration $(\mathrm{Y})$ at $\mathrm{t}$ respectively. Uncertainties on batch dissolution rates were estimated as:

$$
\sigma_{R(t)}=\frac{1}{S * \Delta t * v_{X}} * \sqrt{\sigma_{X(t)^{2}}+\sigma_{X(t-1)^{2}}}
$$

where $\sigma_{X(t)}$ stands for the error on element $\mathrm{X}$ concentrations and $v_{C a}$ for the stoechiometric coefficient of calcium within labradorite. 
Uncertainties on rate $(R)$ ratios were estimated as:

$$
\sigma_{R_{1} / R_{2}}=\frac{R_{1}}{R_{2}} * \sqrt{\frac{\sigma_{R_{1}}{ }^{2}}{{R_{1}}^{2}}+\frac{\sigma_{R_{2}}{ }^{2}}{{R_{2}}^{2}}}
$$

where $\sigma_{R}$ stands for the error estimated on batch rates (see above).

\section{RESULTS}

A summary of the different modalities tested in the present work can be found in Table 1 . Information retrieved from fluid analyses can be found in Table A.1, while data from solid sample observations (VSI, SEM or TEM) are gathered in Table 2.

\subsection{Formation of surface layers}

Surface layers at the fluid-feldspar interface were formed in all samples. At $\mathrm{pH}=1.5$, labradorite dissolution is characterized by an incongruent release of cations into the solution (Fig. 3A). The relative lack of $\mathrm{Si}$ released in the fluid phase depicted by $\mathrm{Ca} / \mathrm{Si}$ values above stoichiometric ratio (Fig. 3A) are due to the formation of a distinct Si-rich layer (Fig. 3B), whose thickness ranges from 7.1 to $26.3 \mu \mathrm{m}$ (Table 2). SEM-EDX and electron diffraction by TEM analyses indicated that the surface layer mainly consists of pure amorphous silica (Fig. 3B). The formation of about $50 \mu \mathrm{m}$-thick ASSLs was also observed with SEM on labradorite crystals reacted at $\mathrm{pH} 1.5$ in silica-rich solutions (Fig. 3C). As shown in Fig. 4, TEM investigations of FIB thin sections revealed thin layers (thickness $<100 \mathrm{~nm}$, see Table 2) at the surface of labradorite crystals reacted at $\mathrm{pH}=2.5$ and 3 . In these experiments, no incongruent cation release was detected as the layers presumably got thinner. At these higher $\mathrm{pH}$ values, the composition of surface layers could hardly be distinguished from the bulk mineral, aside from a modest depletion in alkali and alkaline earth cations.

\section{2. pH-dependence of dissolution rates at the internal and external interfaces}


Our results show that the temporal evolution of labradorite dissolution rate is $\mathrm{pH}$ dependent. At $\mathrm{pH}=1.5, \mathrm{Ca}$ concentration follows a linear trend with time, which reflects constant mineral dissolution rate (Fig. 5). In contrast, cation release at $\mathrm{pH}=3$ was best fitted with a power law, underscoring that reaction rate decreases over time at the internal interface.

Like the internal interface, the reaction rate of the external interface was also $\mathrm{pH}$ dependent. The surface retreats measured by VSI at the external interface evolved linearly at $\mathrm{pH}=1.5$, indicating a constant reaction rate (Fig. 6). In comparison, retreat values measured by VSI at $\mathrm{pH}=3$ were very low (about $500 \mathrm{~nm}$ after 28 days of reaction, i.e. two orders of magnitude smaller than at $\mathrm{pH} 1.5$ for the same duration) and suggested a reduction in the reaction rate.

\subsection{Impact of the anisotropy (experiments run at $\mathrm{pH}=2.5$ )}

Overall, the crystallographic orientation did not measurably affect the reaction rates at the external interface when the reaction was run in aqueous silica-low solutions (Fig. 7). The dissolution rate was reduced only in the (001) crystallographic orientation, similar to the powder experiment (Fig. 8A). In contrast, we found $R(t) / R_{i}>1$ in experiments with the orientations (110), (10 $\overline{1})$ and (010), which underscores an apparent modest increase of the reaction rate. In the experiments conducted in silica-rich solutions, the (001), (010) and (110) orientations exhibited a decrease of dissolution rates similar to that observed for the powdered labradorite experiment in silica-low fluid (Fig. 8B). However, the dissolution rate of the $(10 \overline{1})$ orientation remained approximately constant.

\section{DISCUSSION}

\subsection{Origin of the reduction of dissolution rates}

The possible mechanism explaining the significant $\mathrm{pH}$-dependent reduction of labradorite dissolution rates observed at the internal and external interfaces are discussed below. We considered potential experimental artefacts, as well as the contribution of extrinsic (relative to 
the reaction conditions) and intrinsic factors (relative to the mineral itself). The dataset suggests that the temporal reduction of labradorite dissolution rate is caused by the formation of an amorphous layer with $\mathrm{pH}$-dependent transport properties.

\subsubsection{Experimental artefacts}

Parabolic release of cations such as those obtained at pH 3 (Fig. 5) may stem from the precipitation of secondary phases or the development of diffusion gradients within the reactor due to insufficient stirring (Verney-Carron et al., 2010).

The formation of secondary phases can lead to a gradual uptake of released cations with concomitant change of cation concentrations similar to those displayed in Fig. 5. As reported in Table A.1, however, all experiments initiated in $\mathrm{pH}<3$ solutions were undersaturated $(S I<0)$ with respect to the mineral phases implemented in the EQ36 database, except for high pressure and/or temperature polymorphs of silica that were unlikely to precipitate under our experimental conditions. Experiments conducted at $\mathrm{pH}=3$ reached saturation with respect to a series of secondary Al-bearing phases. However, no significant deviation from the theoretical $\mathrm{Ca} / \mathrm{Al}$ and $\mathrm{Ca} / \mathrm{Si}$ ratios for labradorite was detected (experiments 80-3-0-1, 80-3-0-2 and 80-3-SiO $2-1$, Fig. 9). In addition, SEM observations confirmed the absence of secondary phases in all experiments. Despite being thermodynamically favored, precipitation of gibbsite, boehmite, kaolinite, pyrophillite and beidellite would probably require higher temperature or pressure to overcome the activation barrier of nucleation over the reaction time of this study (see e.g. Eberl and Hower, 1976; Adschiri et al., 1992; Grauby et al., 1993; Bird et al., 1994).

The development of compositional gradients within the reactor can also result in parabolic profiles when the reaction is transport-limited. In the present study, the most rapid dissolution rates among the tested modalities were observed for the experiments at $\mathrm{pH}=1.5$. These experiments yielded linear cation concentration profiles, indicating that the solution 
was sufficiently stirred. Hence, other experiments conducted at higher $\mathrm{pH}$ (i.e. with slower dissolution rates) were not affected by transport-limitation.

Overall, experimental artifacts, such as the formation of secondary minerals or the development of compositional gradients in the reactor, were very unlikely to explain the reduction of the labradorite dissolution rates.

\subsubsection{Extrinsic factors}

The influence of temperature, fluid saturation and $\mathrm{pH}$ on mineral reaction rates is underscored in the following equation (Lasaga, 1984; Lasaga, 1995; Lasaga and Berner, 1998):

$$
r(T, p H)=A * \exp \left(\frac{-E_{a}}{R T}\right) * 10^{-n * p H} * f\left(\Delta G_{r}\right)
$$

where $A$ is the Arrhenius pre-exponential factor, $E_{a}$ is the apparent activation energy of the reaction, $T$ is the absolute temperature, $R$ is the gas constant, $n$ is the reaction order with respect to proton and $f\left(\Delta G_{r}\right)$ accounts for the effect on the rate of the Gibbs free energy of the reaction. As temperature was kept at $80^{\circ} \mathrm{C}$ for all experiments, it can be discarded as potential explanatory extrinsic factor. The effect of $\Delta G_{r}$ variations and $\mathrm{pH}$ drift during the dissolution were estimated for modalities presenting significant changes of their reaction conditions. The theoretical expected rate, accounting for $\Delta G_{r}$ and $\mathrm{pH}$ changes, was calculated based on (i) the initial experimental rate, (ii) $E_{a}$ and $n$ sourced from Palandri and Kharaka (2004) and (iii) the $f\left(\Delta G_{r}\right)$ function, which was taken from the relation determined on labradorite dissolution by Taylor et al. (2000). This relation showed that labradorite dissolution rate measured at $25^{\circ} \mathrm{C}$ is $\Delta G_{r}$-independent as long as $\Delta G_{r}<-42 \mathrm{~kJ} / \mathrm{mol}$. As $\Delta G_{r}$ remained systematically below -42 $\mathrm{kJ} / \mathrm{mol}$ for all experiments (Table A.1), it did not significantly contribute to the temporal decline of the dissolution rate. Detailed simulations of the evolution of cation concentration (equation 12) and of the corresponding reaction rate for experiments with the highest $\mathrm{pH}$ 
variations confirmed that the impact of $\mathrm{pH}$ and $\Delta G_{r}$ on the reaction rate can be considered as negligible (e.g. Fig. 10).

Finally, the Al concentration may also control the dissolution rate of feldspar minerals (Oelkers et al., 1994), although this "Al-effect" has been questioned in several studies (e.g. Burch et al., 1993; Lasaga, 1995; Lüttge, 2006; Hellmann et al., 2010).In our case, Al was likely not a primary parameter explaining the reduction of labradorite dissolution rates, as dissolution rates remained constant in experiments with the greatest $\mathrm{Al}$ concentrations $(\mathrm{pH}=1.5)$. In addition, we investigated the correlation between the reaction rate and the parameter $\frac{a_{H^{+}}^{3 n}}{a_{A l^{3+}}^{n}}$ (Fig. 11), where $\mathrm{n}$ refers to a stoichiometric coefficient equal to the number of Al ions in the potential precursor sites involved in the rate limiting step of the dissolution reaction (Oelkers et al., 1994; Schott and Oelkers, 1995). The lack of correlation between $\frac{a_{H^{+}}^{3 n}}{a_{A l^{3+}}^{n}}$ and the labradorite dissolution rate (R2=0.23, Fig. 11), confirmed that the Al-effect was not a primary rate-controlling factor. To sum up, extrinsic parameters evaluated in this study did not appear to contribute significantly to the reduction of reaction rates observed at $\mathrm{pH}>1.5$.

\subsubsection{Intrinsic factors}

The origin of parabolic cation release has been previously debated and attributed (i) to the formation of surface layers, supposed to affect the transport properties of aqueous species at the fluid-mineral interface (Correns and von Engelhardt, 1938; Wollast, 1967; Helgeson, 1971; Luce et al., 1972; Busenberg and Clemency, 1976), and (ii) to the preferential dissolution of high energy sites or ultrafine particles during the early stages of the dissolution as a result of intrinsic structural defects or sample preparation (Lagache, 1961; Lagache, 1965; Holdren and Berner, 1979; Schott et al., 1981). 
A transitional effect due to the dissolution of ultrafine particles is unlikely in our case as we used a well-standardized elimination protocol that was previously proven efficient (Schott et al., 1981). In addition, reduction of labradorite dissolution rate was also observed on the polished surfaces, which are unlikely to be covered with ultrafine particles.

The contribution of high surface energy sites was evaluated based on the extent of reaction from which significant reduction of dissolution rate started. In our case, this value depended on the reaction conditions (Fig. 12). In contrast, reaction rates controlled by the consumption of high surface energy sites are expected to be lower after comparable extents of reaction, whatever the $\mathrm{pH}$ conditions.

As none of the aforementioned processes could reasonably explain the reduction of labradorite dissolution rate, surface layers likely represent the only explanatory factor. Supporting this argument are the observations that (i) thin surface layers are formed at $\mathrm{pH}>$ 1.5, with a characteristic thickness of surface passivation (Daval et al., 2011; Daval et al., 2013; Sissmann et al., 2013; Saldi et al., 2015; Maher et al., 2016); (ii) the aqueous silica level exerts a first order control on the labradorite dissolution rate (Fig. 13), as expected when mineral surfaces are covered with passivating ASSL (e.g. Daux et al., 1997; Grambow and Muller, 2001; Daval et al., 2011; Daval et al., 2013; Johnson et al., 2014).

\subsection{Influence of control parameters and mechanisms involved}

\subsubsection{Internal interface}

As illustrated on Fig. 5 and Fig. 12, higher $\mathrm{pH}$ values resulted in larger relative decrease of labradorite reaction rate during the reaction. This may be explained by the $\mathrm{pH}-$ sensitivity of the constituent phase of the surface layer. The phase consisted here in amorphous silica at $\mathrm{pH}=1.5$, and an $\mathrm{Al} / \mathrm{Si}$-rich or $\mathrm{Si}$-rich phase at higher $\mathrm{pH}$, in agreement with studies of thin surface layers developed on altered feldspars (e.g. Nugent et al., 1998; Kawano and Tomita, 2001; Zhu et al., 2006; Hellmann et al., 2012). 
As reported for ASSLs formed on silicate glasses (e.g. Verney-Carron et al., 2010), we propose that the properties of the surface layers formed on minerals are $\mathrm{pH}$-dependent, resulting in different transport properties. The degraded transport properties may then influence the mineral dissolution, with non-passivating characteristics at $\mathrm{pH}=1.5$ and gradual transport control with increasing $\mathrm{pH}$. The progressive increase of passivating properties through time is reflected by a release profile of cations that did not strictly follow a parabolic law (proportional to $t^{\frac{1}{2}}$ ). This could be explained by the progressive evolution of the layer's properties through time due to continuous fluid-layer contact (Putnis et al., 2005; Putnis, 2009) similar to ageing of silica sols (Melero-Garcia et al., 2009), or the ageing of amorphous precursor to secondary phases, such as pseudoboehmite or pregibbsite gels (McHardy, 1971; Bottero et al., 1980; Bird et al., 1994; Tsuchida, 2000).

The $\mathrm{pH}$-dependent transport properties of surface layers may be explained by the competition between the intrinsic kinetics of labradorite dissolution and surface layer densification (see Daval et al., 2009b) Schematically, if labradorite dissolution is faster than layer densification, then the dissolution may proceed unhindered. On the other hand, if layer densification is faster than labradorite dissolution, it will ultimately result in passivation of the mineral surface. Arguably, the initial dissolution rate of labradorite dissolution is $\mathrm{pH}$ dependent, and increases with decreasing $\mathrm{pH}$ (compare, for instance, initial rate reported for $\mathrm{pH}=1.5$ and $\mathrm{pH}=3$ on Fig. 12). Alternatively, oligomerization of aqueous silica, which represents the first steps towards $\mathrm{SiO}_{2}$ (am) formation, is also $\mathrm{pH}$-dependent (e.g. Icopini et al., 2005). The oligomerization rate increases with increasing $\mathrm{pH}$. If the oligomerization of $\mathrm{SiO}_{2}(\mathrm{aq})$ is considered as a relevant proxy for silica layer densification, then it is obvious that the densification rate is faster when $\mathrm{pH}$ is less acidic. As a consequence, both labradorite dissolution rate and layer densification rate evolve in such a way that passivation is expected in less acidic environments, in fairly good agreement with our results. This reasoning would 


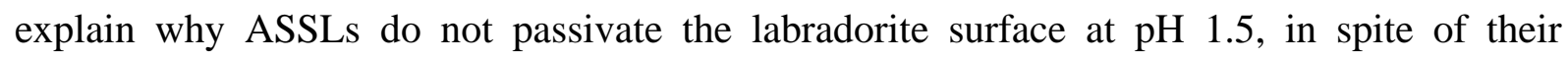
thickness.

To further understand the mechanisms affecting the bulk labradorite dissolution, we tested the effect of anisotropy on the passivating ability of the surface layers in dissolution experiments with specific crystal orientations (Fig. 8). The most striking feature is that of the relative decrease of dissolution rate over time of the main labradorite cleavage (001), corresponds to that observed in the powder experiments at $\mathrm{pH}=2.5$ in unsaturated conditions (Fig. 8A). This shows that the passivation behavior of the statistically most abundant orientation within a mineral powder, reasonably assumed here to be the preferential cleavage of labradorite (001), is representative of passivation behavior of the powder. Moreover, the effect of surface layers is face-specific. The behavior of (110) orientation, which was not passivated in pure $\mathrm{HCl}$ solution ( $\mathrm{pH} 2.5)$, was close to that of powder and (001) experiments when saturated with respect to amorphous silica. Orientation (010) displays the same evolution, while (101) was not passivated under either condition. On the whole, (001) orientation seems to be the only passivated orientation in an undersaturated fluid, while (10 $\overline{1})$ was the only non-passivated orientation amongst those tested in a saturated fluid. Consistent with the mechanism leading to passivation proposed above, the the fact that the (001) face is among the slowest dissolving faces of feldspars (Zhang and Lüttge, 2009; Pollet-Villard et al., 2016) may explain why it was the sole face that was systematically passivated at $\mathrm{pH} 2.5$.

To sum up, the temporal evolution of the dissolution rate of the internal interface is likely controlled by the spontaneous evolution of the textural properties of the surface layer, such as its densification, which is $\mathrm{pH}$-dependent. The evolution of the external interface dissolution rate further suggests an intrinsic change of the structural properties of the surface layer itself. 


\subsubsection{External interface}

The dissolution rate of the external interface is globally isotropic (Fig. 7), which indirectly supports that the structure and chemical composition of the surface layers are similar regardless of the considered face. Moreover, rates reported at $\mathrm{pH}=2.5$ are about two orders of magnitude slower in saturated fluids (ranging from $3.310^{-11}$ to $1.410^{-10} \mathrm{~mol} . \mathrm{m}^{-2} . \mathrm{s}^{-1}$ ) than those for non-saturated fluids under the same conditions (from $1.110^{-8}$ to $2.010^{-8}$ mol.m ${ }^{2} \cdot \mathrm{s}^{-1}$, Table 2). Such a dramatic sensitivity of the dissolution rate of the external interface on the aqueous concentration of silica indicates that the surface layer is primary made of silica. An additional striking observation is that the reactivity of the external interface gradually decreased as a function of time at $\mathrm{pH} 3$, whereas it remained constant at $\mathrm{pH} 1.5$ (Fig. 6). Since the dissolution of the external interface is chemically-controlled (as opposed to the dissolution of the internal interface which has been shown to be controlled by the transport properties of the layer), the most likely explanation for the intrinsic decrease of the surface layer reactivity is that it either chemically or structurally evolved with time. In particular, a similar chemically-controlled dependence of the surface layer dissolution rate on its structure was previously shown by the decline of the release of Si from wollastonite during the progressive polymerization of the ASSL (Schott et al., 2012).

Altogether, our results point out that the dissolution of labradorite at $\mathrm{pH}>1.5$ is characterized by an evolution of the reactivity of the external and internal interfaces. This evolution may be attributed to the concomitant evolution of the structural and textural properties of the surface layers, which is $\mathrm{pH}-\mathrm{dependent.}$

\subsection{Implication of interfacial control of dissolution rates of altered surface layer}

To the best of our knowledge, the interpretations proposed above are not at odds with previously published data. In particular, several studies (Knauss and Wolery, 1986; Carroll 
and Knauss, 2005) reported cation release profiles that were not strictly linear, despite tremendous efforts involved in the solid phase preparation.

Under field conditions, surface layers have been observed to form under various weathering conditions, either on laboratory-grade (Nugent et al., 1998) or in environmental feldspar samples (Kawano and Tomita, 2001; Zhu et al., 2006; Hellmann et al., 2012). The passivating mechanism revealed in the present study may therefore be relevant to field conditions. A systematic characterization of the textural and compositional properties of feldspar mineral surface layers (e.g. the diffusivity (Gin et al., 2015), density (Rebiscoul et al., 2003; Rebiscoul et al., 2004) and texture (Schott et al., 2012)) could therefore be considered at the field scale. However, results from such studies may be complicated by the thickness of the layers, which in most cases prevent obtaining quantitative data (Zhu et al., 2006).

Because passivation is an increasing function of $\mathrm{pH}$, we anticipate that the process associated with the reduction of the dissolution rates, such as evolution of textural or structural properties of interfacial layers, will be particularly relevant at $\mathrm{pH}$ typically found in continental soils. The effect of lowering temperature from $80^{\circ} \mathrm{C}$ to ambient temperature, however, remains unclear. The respective contribution of labradorite dissolution and layer densification to the dissolution reduction at lower temperature is a function of the activation energy of these processes, which is currently unknown. However, previous studies suggest that for minerals such as olivine or wollastonite, passivation is enhanced at lower temperature (Daval et al., 2009a). Consequently, a much slower maturation of the surface layer is expected at field-relevant temperatures.

\section{CONCLUSION}

The present study shows that the reactivity of labradorite feldspar at $\mathrm{pH}>1.5$, rather than being constant, is controlled by the ageing of the properties of the outermost part of the 
mineral, at the interface with the reacting fluid. The dissolution patterns of labradorite feldspar in acidic fluid at $80^{\circ} \mathrm{C}$ enabled us to relate the evolution of the reaction rate to the formation of a surface layer. The solution $\mathrm{pH}$ appeared to control the textural and structural properties at this interface, ultimately governing the rate of matter and energy exchanges. At $\mathrm{pH}=1.5$, surface layers are permissive enough to enable direct fluid-mineral interaction. In contrast, layers formed at higher $\mathrm{pH}$ values exhibited increasing passivating properties over time due to putative changes in their textural and structural properties. The decrease of the reaction rate also depends on crystallographic orientation, as revealed by a series of facespecific experiments. In this way, the behavior of the principal cleavage of labradorite, namely the (001) crystallographic orientation, was shown to be representative of the bulk behavior of associated mineral powder.

Principal outcomes of this study are: (i) the current quasi univocal understanding of dissolution rate constant should be revised in favor of more specific scenarii that would account for interfacial properties, (ii) further efforts should be directed towards a better understanding of the functioning of this interface on different crystal faces, including the most exposed one (001), and (iii) the early to transitional stages of mineral dissolution should be considered, as they may contain critical information to understand mineral reactivity in fieldrelevant conditions.

\section{ACKNOWLEDGEMENTS}

The authors wish to warmly acknowledge Martiane Cabié, Gilles Morvan, René Boutin and Helline Maison for analytical support. Constructive review and positive comments by two anonymous reviewers and the editor (Jeremy Fein) were much appreciated and helped improve the manuscript. This research has been funded through a grant attributed to Damien Daval under the framework of the VALVE project (EC2CO-BIOHEFECT program coordinated by the CNRS-INSU). Kevin G. Knauss effort at LBL was supported by the 
Director, Office of Science, Office of Basic Energy Sciences, Chemical Sciences,

Geosciences, and Biosciences Division, of the U.S. Department of Energy under Contract No.

DE-AC02-05CH11231. Bastien Wild was supported by a PhD fellowship of the Ecole

Doctorale "Sciences de la Terre et Environnement" (ED n 413).

\section{BIBLIOGRAPHY}

Abramoff, M.D.M., P.J.; Ram, S.J., 2004. Image Processing with ImageJ. Biophotonics International, 7: 36-42.

Adschiri, T., Kanazawa, K., Arai, K., 1992. Rapid and continuous hydrothermal synthesis of boehmite particles in subcritical and supercritical water. Journal of the American Ceramic Society, 75(9): 2615-2618.

Arvidson, R.S., Beig, M.S., Lüttge, A., 2004. Single-crystal plagioclase feldspar dissolution rates measured by vertical scanning interferometry. American Mineralogist, 89(1): 51-56.

Beaulieu, E., Godderis, Y., Donnadieu, Y., Labat, D., Roelandt, C., 2012. High sensitivity of the continental-weathering carbon dioxide sink to future climate change. Nature Climate Change, 2(5): 346-349.

Bird, M.I., Longstaffe, F.J., Fyfe, W.S., Tazaki, K., Chivas, A.R., 1994. Oxygen-isotope fractionation in gibbsite synthesis experiments versus natural samples. Geochimica et Cosmochimica Acta, 58(23): 5267-5277.

Bottero, J.Y., Cases, J.M., Fiessinger, F., Poirier, J.E., 1980. Studies of hydrolyzed aluminium-chloride solutions. 1.Nature of aluminium species and composition of aqueous solutions. Journal of Physical Chemistry, 84(22): 2933-2939.

Burch, T.E., Nagy, K.L., Lasaga, A.C., 1993. Free energy dependence of albite dissolution kinetics at $80^{\circ} \mathrm{C}$ and $\mathrm{pH}$ 8.8. Chemical Geology, 105: 137-162.

Busenberg, E., Clemency, C.V., 1976. Dissolutions kinetics of feldspars at $25^{\circ} \mathrm{C}$ and $1 \mathrm{~atm}$ CO2 partial pressure. Geochimica et Cosmochimica Acta, 40(1): 41-49.

Carroll, S.A., Knauss, K.G., 2005. Dependence of labradorite dissolution kinetics on $\mathrm{CO} 2(\mathrm{aq}), \mathrm{Al}(\mathrm{aq})$, and temperature. Chemical Geology, 217: 213-225.

Correns, C.W., von Engelhardt, W., 1938. Neue Untersuchungen über die Verwitterung des Kalifeldspates. Naturwissenschaften, 26(9): 137-138.

Daux, V., Guy, C., Advocat, T., Crovisier, J.L., Stille, P., 1997. Kinetic aspects of basaltic glass dissolution at $90^{\circ} \mathrm{C}$ : role of aqueous silicon and aluminium. Chemical Geology, 142(12): $109-126$. 
Daval, D., Hellmann, R., Saldi, G.D., Wirth, R., Knauss, K.G., 2013. Linking nm-scale measurements of the anisotropy of silicate surface reactivity to macroscopic dissolution rate laws: New insights based on diopside. Geochimica et Cosmochimica Acta, 107(0): 121-134.

Daval, D., Martinez, I., Corvisier, J., Findling, N., Goffe, B., Guyot, F., 2009a. Carbonation of Ca-bearing silicates, the case of wollastonite: Experimental investigations and kinetic modeling. Chemical Geology, 265(1-2): 63-78.

Daval, D., Martinez, I., Guigner, J.M., Hellmann, R., Corvisier, J., Findling, N., Dominici, C., Goffe, B., Guyot, F., 2009b. Mechanism of wollastonite carbonation deduced from micro- to nanometer length scale observations. American Mineralogist, 94(11-12): 1707-1726.

Daval, D., Sissmann, O., Menguy, N., Saldi, G.D., Guyot, F., Martinez, I., Corvisier, J., Garcia, B., Machouk, I., Knauss, K.G., Hellmann, R., 2011. Influence of amorphous silica layer formation on the dissolution rate of olivine at $90^{\circ} \mathrm{C}$ and elevated $\mathrm{pCO}(2)$. Chemical Geology, 284(1-2): 193-209.

Eberl, D., Hower, J., 1976. Kinetics of illite formation. Geological Society of America Bulletin, 87(9): 1326-1330.

Fantle, M.S., DePaolo, D.J., 2006. Sr isotopes and pore fluid chemistry in carbonate sediment of the Ontong Java Plateau: Calcite recrystallization rates and evidence for a rapid rise in seawater Mg over the last 10 million years. Geochimica et Cosmochimica Acta, 70(15): 38833904.

Fischer, C., Arvidson, R.S., Lüttge, A., 2012. How predictable are dissolution rates of crystalline material? Geochimica et Cosmochimica Acta, 98(0): 177-185.

Fischer, C., Kurganskaya, I., Schäfer, T., Lüttge, A., 2014. Variability of crystal surface reactivity: What do we know? Applied Geochemistry, 43(0): 132-157.

Gin, S., Jollivet, P., Fournier, M., Angeli, F., Frugier, P., Charpentier, T., 2015. Origin and consequences of silicate glass passivation by surface layers. Nature Communications, 6: 6360.

Godderis, Y., Williams, J.Z., Schott, J., Pollard, D., Brantley, S.L., 2010. Time evolution of the mineralogical composition of Mississippi Valley loess over the last $10 \mathrm{kyr}$ : Climate and geochemical modeling. Geochimica et Cosmochimica Acta, 74(22): 6357-6374.

Gout, R., Oelkers, E.H., Schott, J., Zwick, A., 1997. The surface chemistry and structure of acid-leached albite: New insights on the dissolution mechanism of the alkali feldspars.

Geochimica et Cosmochimica Acta, 61(14): 3013-3018.

Grambow, B., Muller, R., 2001. First-order dissolution rate law and the role of surface layers in glass performance assessment. Journal of Nuclear Materials, 298(1-2): 112-124.

Grauby, O., Petit, S., Decarreau, A., Baronnet, A., 1993. The beidellite-saponite series: an experimental approach. European Journal of Mineralogy, 5(4): 623-635. 
Helgeson, H.C., 1971. Kinetics of mass transfer among silicates and aqueous solutions. Geochimica et Cosmochimica Acta, 35: 421-469.

Hellmann, R., Daval, D., Tisserand, D., 2010. The dependence of albite feldspar dissolution kinetics on fluid saturation state at acid and basic $\mathrm{pH}$ : Progress towards a universal relation. Comptes Rendus Geoscience, 342(7-8): 676-684.

Hellmann, R., Eggleston, C.M., Hochella, M.F.J., Crerar, D.A., 1990. The formation of leached layers on albite surfaces during dissolution under hydrothermal conditions. Geochimica et Cosmochimica Acta, 54: 1267-1281.

Hellmann, R., Penisson, J.-M., Hervig, R.L., Thomassin, J.-H., Abrioux, M.-F., 2003. An EFTEM/HRTEM high-resolution study of the near surface of labradorite feldspar altered at acid $\mathrm{pH}$ : evidence for interfacial dissolution-reprecipitation. Physics and Chemistry of Minerals, 30(4): 192-197.

Hellmann, R., Penisson, J.-M., Hervig, R.L., Thomassin, J.-H., and Abrioux, M.F., 2004. Chemical alteration of feldspar: a comparative study using SIMS and HRTEM/EFTEM. In: R.B. Wanty, R.R.S.I. (Editor), Water Rock Interaction. A.A. Balkema, pp. 753-756.

Hellmann, R., Wirth, R., Daval, D., Barnes, J.-P., Penisson, J.-M., Tisserand, D., Epicier, T., Florin, B., Hervig, R.L., 2012. Unifying natural and laboratory chemical weathering with interfacial dissolution-reprecipitation: A study based on the nanometer-scale chemistry of fluid-silicate interfaces. Chemical Geology, 294-295(0): 203-216.

Holdren, G.R., Berner, R.A., 1979. Merchanism of feldspar weathering. 1. Experimental studies. Geochimica et Cosmochimica Acta, 43(8): 1161-1171.

Icopini, G.A., Brantley, S.L., Heaney, P.J., 2005. Kinetics of silica oligomerization and nanocolloid formation as a function of $\mathrm{pH}$ and ionic strength at $25^{\circ} \mathrm{C}$. Geochimica et Cosmochimica Acta, 69(2): 293-303.

Johnson, N.C., Thomas, B., Maher, K., Rosenbauer, R.J., Bird, D., Brown Jr, G.E., 2014. Olivine dissolution and carbonation under conditions relevant for in situ carbon storage. Chemical Geology, 373(0): 93-105.

Kawano, M., Tomita, K., 2001. TEM-EDX study of weathered layers on the surface of volcanic glass, bytownite, and hypersthene in volcanic ash from Sakurajima volcano, Japan. American Mineralogist, 86(3): 284-292.

Knauss, K.G., Wolery, T.J., 1986. Dependence of albite dissolution kinetics on pH and time at $25^{\circ} \mathrm{C}$ and $70^{\circ} \mathrm{C}$. Geochimica et Cosmochimica Acta, 50(11): 2481-2497.

Lagache, M., 1965. Contribution a I'étude de I'altération des feldspaths, dans l'eau, entre 100 et $200^{\circ} \mathrm{C}$ sous divers pressions de $\mathrm{CO} 2$, et application à la synthèse des minéraux. Bulletin de la Société française de minéralogie et de cristallographie, 88: 223-253.

Lagache, M., 1976. New data on the kinetics of the dissolution of alkali feldspars at $200^{\circ} \mathrm{C}$ in CO2 charged water. Geochimica et Cosmochimica Acta, 40(2): 157-161. 
Lagache, M.W., J.; Sabatier, G., 1961. Etude de la dissolution des feldspaths alcalins dans l'eau pure ou chargée de CO2 à $200{ }^{\circ} \mathrm{C}$. Acad. Sci. Paris, Comptes Rendus, 253: 2019-2022.

Lasaga, A.C., 1984. Chemical kinetics of water-rocks interactions. Journal of Geophysical Research, 89(NB6): 4009-4025.

Lasaga, A.C., 1995. Fundamental approaches in describing mineral dissolution and precipitation rates. In: White, A.F., Brantley, S.L. (Eds.), Chemical Weathering Rates of Silicate Minerals. Mineralogical Society of America, pp. 23-86.

Lasaga, A.C., Berner, R.A., 1998. Fundamental aspects of quantitative models for geochemical cycles. Chemical Geology, 145(3-4): 161-175.

Lee, M.R., Brown, D.J., Smith, C.L., Hodson, M.E., Mackenzie, M., Hellmann, R., 2007. Characterization of mineral surfaces using FIB and TEM: A case study of naturally weathered alkali feldspars. American Mineralogist, 92(8-9): 1383-1394.

Luce, R.W., Bartlett, R.W., Parks, G.A., 1972. Dissolution kinetics of magnesium silicates. Geochimica et Cosmochimica Acta, 36(1): 33-50.

Lüttge, A., 2006. Crystal dissolution kinetics and Gibbs free energy. Journal of Electron Spectroscopy and Related Phenomena, 150(2-3): 248-259.

Maher, K., DePaolo, D.J., Lin, J.C.F., 2004. Rates of silicate dissolution in deep-sea sediment: In situ measurement using U-234/U-238 of pore fluids. Geochimica et Cosmochimica Acta, 68(22): 4629-4648.

Maher, K., Johnson, N.C., Jackson, A., Lammers, L.N., Torchinsky, A.B., Weaver, K.L., Bird, D.K., Brown Jr, G.E., 2016. A spatially resolved surface kinetic model for forsterite dissolution. Geochimica et Cosmochimica Acta, 174: 313-334.

McHardy, W.J.T., A. P., 1971. Conditions for the formation of bayerite and gibbsite. Mineralogical magazine, 38: 358-368.

Melero-Garcia, E., Santisteban-Bailon, R., Garcia-Ruiz, J.M., 2009. Role of Bulk pH during Witherite Biomorph Growth in Silica Gels. Crystal Growth \& Design, 9(11): 4730-4734.

Nugent, M.A., Brantley, S.L., Pantano, C.G., Maurice, P.A., 1998. The influence of natural mineral coatings on feldspar weathering. Nature, 395(6702): 588-591.

Oelkers, E.H., Schott, J., Devidal, J.-L., 1994. The effect of aluminum, pH, and chemical affinity on the rates of aluminosilicate dissolution reactions. Geochimica et Cosmochimica Acta, 58: 2011-2024.

Olsson, B.A., Bengtsson, J., Lundkvist, H., 1996. Effects of different forest harvest intensities on the pools of exchangeable cations in coniferous forest soils. Forest Ecology and Management, 84(1-3): 135-147. 
Palandri, J.L., Kharaka, Y.K., 2004. A compilation of rate parameters of water-mineral interaction kinetics for application to geochemical modeling, U.S. Geological Survey, Open File Report.

Pollet-Villard, M., Daval, D., Ackerer, P., Saldi, G.D., Wild, B., Knauss, K.G., Fritz, B., 2016. Does crystallographic anisotropy prevent the conventional treatment of aqueous mineral reactivity? A case study based on K-feldspar dissolution kinetics. Geochimica Et Cosmochimica Acta, 190: 294-308.

Porder, S., Hilley, G.E., Chadwick, O.A., 2007. Chemical weathering, mass loss, and dust inputs across a climate by time matrix in the Hawaiian Islands. Earth and Planetary Science Letters, 258(3-4): 414-427.

Putnis, A., 2009. Mineral Replacement Reactions. Thermodynamics and Kinetics of WaterRock Interaction, 70: 87-124.

Putnis, C.V., Tsukamoto, K., Nishimura, Y., 2005. Direct observations of pseudomorphism: compositional and textural evolution at a fluid-solid interface. American Mineralogist, 90(1112): 1909-1912.

Rebiscoul, D., van der Lee, A., Frugier, P., Ayral, A., Gin, S., 2003. X-ray reflectometry characterization of SON 68 glass alteration films. Journal of Non-Crystalline Solids, 325(1-3): 113-123.

Rebiscoul, D., Van der Lee, A., Rieutord, F., Ne, F., Spalla, O., El-Mansouri, A., Frugier, P., Ayral, A., Gin, S., 2004. Morphological evolution of alteration layers formed during nuclear glass alteration: new evidence of a gel as a diffusive barrier. Journal of Nuclear Materials, 326(1): 9-18.

Saldi, G.D., Daval, D., Guo, H., Guyot, F., Bernard, S., Le Guillou, C., Davis, J.A., Knauss, K.G., 2015. Mineralogical evolution of Fe-Si-rich layers at the olivine-water interface during carbonation reactions. American Mineralogist, 100(11-12): 2655-2669.

Schneider, C.A., Rasband, W.S., Eliceiri, K.W., 2012. NIH Image to ImageJ: 25 years of image analysis. Nature Methods, 9(7): 671-675.

Schott, J., Berner, R.A., Lennart Sjöberg, E., 1981. Mechanism of pyroxene and amphibole weathering--I. Experimental studies of iron-free minerals. Geochimica et Cosmochimica Acta, 45(11): 2123-2135.

Schott, J., Oelkers, E.H., 1995. Dissolution and crystallization rates of silicate minerals as a function of chemical affinity. Pure and Applied Chemistry, 67(6): 903-910.

Schott, J., Pokrovsky, O.S., Spalla, O., Devreux, F., Gloter, A., Mielczarski, J.A., 2012. Formation, growth and transformation of leached layers during silicate minerals dissolution: The example of wollastonite. Geochimica et Cosmochimica Acta, 98: 259-281.

Sissmann, O., Daval, D., Brunet, F., Guyot, F., Verlaguet, A., Pinquier, Y., Findling, N., Martinez, I., 2013. The deleterious effect of secondary phases on olivine carbonation yield: 
Insight from time-resolved aqueous-fluid sampling and FIB-TEM characterization. Chemical Geology, 357(0): 186-202.

Taylor, A.S., Blum, J.D., Lasaga, A.C., 2000. The dependence of labradorite dissolution and $\mathrm{Sr}$ isotope release rates on solution saturation state. Geochimica et Cosmochimica Acta, 64(14): 2389-2400.

Testemale, D., Dufaud, F., Martinez, I., Benezeth, P., Hazemann, J.L., Schott, J., Guyot, F., 2009. An X-ray absorption study of the dissolution of siderite at 300 bar between $50^{\circ} \mathrm{C}$ and $100^{\circ} \mathrm{C}$. Chemical Geology, 259(1-2): 8-16.

Tsuchida, T., 2000. Hydrothermal synthesis of submicrometer crystals of boehmite. Journal of the European Ceramic Society, 20(11): 1759-1764.

Van der Lee, J., De Windt, L., 2002. CHESS Tutorial and Cookbook. Updated for version 3.0., Manual Nr. LHM/RD/02/13, Paris, 116 pp.

Verney-Carron, A., Gin, S., Frugier, P., Libourel, G., 2010. Long-term modeling of alterationtransport coupling: Application to a fractured Roman glass. Geochimica et Cosmochimica Acta, 74(8): 2291-2315.

Wang, F., Giammar, D.E., 2013. Forsterite Dissolution in Saline Water at Elevated Temperature and High CO2 Pressure. Environmental Science \& Technology, 47(1): 168-173.

White, A.F., Brantley, S.L., 2003. The effect of time on the weathering of silicate minerals: why do weathering rates differ in the laboratory and field? Chemical Geology, 202(3-4): 479506.

White, A.F., Schulz, M.S., Vivit, D.V., Bullen, T.D., Fitzpatrick, J., 2012. The impact of biotic/abiotic interfaces in mineral nutrient cycling: A study of soils of the Santa Cruz chronosequence, California. Geochimica et Cosmochimica Acta, 77: 62-85.

Wollast, R., 1967. Kinetics of the alteration of K-feldspar in buffered solutions at low temperature. Geochimica et Cosmochimica Acta, 31(4): 635-648.

Zhang, L., Lüttge, A., 2009. Theoretical approach to evaluating plagioclase dissolution mechanisms. Geochimica et Cosmochimica Acta, 73(10): 2832-2849.

Zhu, C., 2005. In situ feldspar dissolution rates in an aquifer. Geochimica et Cosmochimica Acta, 69(6): 1435-1453.

Zhu, C., Veblen, D.R., Blum, A.E., Chipera, S.J., 2006. Naturally weathered feldspar surfaces in the Navajo Sandstone aquifer, Black Mesa, Arizona: Electron microscopic characterization. Geochimica et Cosmochimica Acta, 70(18): 4600-4616.

\section{FIGURE LEGENDS}


Fig. 1. Determination of large surface retreats $(>0.1 \mu \mathrm{m})$. Surface topography is acquired by VSI for each sample prior to and after dissolution. Linear height profiles are measured across the masked area indicated by a grey dashed contour at the exact same location on both maps (A). Linear regression (dashed lines) for each profile was retrieved from a portion of the masked zone that remained preserved from dissolution (B). The parameters of these regressions were used for correcting their respective tilts $(\mathrm{C})$, and corrected profiles were subtracted to estimate the surface retreat (D). The red rectangles indicate the ranges of topography variations due to surface roughness.

Fig. 2. Determination of small surface retreats $(<100 \mathrm{~nm})$. VSI images were acquired in the direct vicinity of the boundary between the masked and the unmasked portions of the surface (A). The mean surface retreats were measured based on the most representative heights of each portion (B) from the histogram plots (C). The profile (D) corresponds to the mean heights across the grey rectangle shown in B.

Fig. 3 . Formation of ASSLs in experiments conducted in $\mathrm{pH}=1.5 \mathrm{HCl}$ solutions at $80^{\circ} \mathrm{C}$. The error bars indicate the analytical uncertainty of the $\Delta C a / \Delta S i$ rartio (A) as calculated via error propagation. Bold horizontal line indicates $\mathrm{Ca} / \mathrm{Si}$ stoichiometric ratio in Labradorite. SEM micrograph acquired on sample cross sections of labradorite samples reacted in aqueous silica-low solutions at $\mathrm{pH}=1.5$ for 4 days $(\mathrm{B})$, or reacted in solutions saturated with respect to amorphous silica for 60 days (C).

Fig. 4. TEM micrographs at the outer boundary of labradorite samples reacted at $80^{\circ} \mathrm{C}$ in aqueous silica-low solutions at $\mathrm{pH}=3$ for 28 days and $\mathrm{pH}=2.5$ for 12 days. 
Fig. 5. Cation release from labradorite dissolution at $80^{\circ} \mathrm{C}$ in aqueous silica-low solutions at $\mathrm{pH}=1.5$ (green diamonds) and $\mathrm{pH}=3$ (red squares). Coefficients of determination for each fit are displayed. ICP-AES errors of concentrations are about the size of symbols used.

Fig. 6. Surface retreat as a function of reaction time for (001) and (010) orientations for $\mathrm{pH}=1.5(\mathrm{~A})$ and $\mathrm{pH}=3$ (B) experiments conducted in silica-low solutions, indicative of the reactiviy of the external interface. The large error bars are due to the significant increase of surface roughness.

Fig. 7. Dissolution rate at the external interface in $\mathrm{mol} / \mathrm{m}^{2} / \mathrm{s}$ for various orientations tested at $\mathrm{pH}=2.5$ in both silica-low (A) and silica-rich (B) solutions. The dissolution rates were calculated based on VSI measurement, and the error bars are derived from uncertainty on retreat measurements.

Fig. 8. Temporal variation of the ratios of instantaneous rates $(R(t))$ at the internal interface to the initial rate $\left(R_{i}\right)$ for experiments at $\mathrm{pH}=2.5$. Cation release was recorded independently for each specific orientation. A ratio value $R(t) / R_{i}<1$ accounts for a reduction of the reaction rate with time, while $R(t) / R_{i}>1$, stands for an acceleration of the reaction rate. Error bars indicate error on ratios due to uncertainties on ICP-AES measurements and were calculated following the methodology presented in section 2.7 . 
Fig. 9. $\mathrm{Ca} / \mathrm{Si}(\mathrm{A})$ and $\mathrm{Ca} / \mathrm{Al}(\mathrm{B})$ elemental ratios for $\mathrm{pH}=3$ experiments conducted in aqueous silica-low (red and purple squares) or in silica-rich solutions (orange squares). Error bars indicate error on elemental ratios derived from uncertainties on ICP-AES measurements.

Fig. 10. Elemental release for 3-80-0-2 experiment conducted at $\mathrm{pH} 3$ in a silica-low solution (red squares) compared with the theoretical values (black diamonds) and taking into account measured $\mathrm{pH}$ and $\Delta G_{r}$ drifts (grey diamonds).

Fig. 11. $\log ($ rate) versus Al effect parameter (Oelkers et al., 1994).

Fig. 12. Reaction rate $\left(\mathrm{mol} / \mathrm{m}^{2} / \mathrm{s}\right)$ based on Ca release into solution as a function of the extent of reaction $\left(\mathrm{mol} / \mathrm{m}^{2}\right)$ at various $\mathrm{pH}$ conditions. Diamonds correspond to experiments conducted at $\mathrm{pH} 1.5$ on polished surfaces, circles to powder experiments at $\mathrm{pH}=2$, triangles to powder experiments at $\mathrm{pH}=2.5$ and squares to experiments on polished surfaces at $\mathrm{pH}=3$. (B) is a close-up view of (A). Reported errorbars exclusively account for ICP-AES uncertainties as calculated via error propagation.

Fig. 13. Rate ratios for experiments conducted at $80^{\circ} \mathrm{C}$ in $\mathrm{HCl}$ solutions at $\mathrm{pH}=1.5$ (green diamonds) and $\mathrm{pH}=3$ (red squares). A value $>1$ accounts for a higher rate recorded in experiments conducted in silica-low solutions. Results are based on Al (A) and Ca (B) data. Error bars indicate error on ratios due to uncertainties on ICP-AES measurements. 
Table 1 : Summary of experiments conducted with oriented single crystal surfaces. For some experiments, the reacting fluid was saturated with respect to amorphous silica $\left(\mathrm{SiO}_{2}(\mathrm{am})\right.$, see text). Numbers within brackets correspond to the Miller indices of the polished face. Two additional experiments were conducted on labradorite powders in silica-low fluids at $\mathrm{pH}=2.5(80-2.5-0-\mathrm{P})$ and 2 (80-2-0-P).

* Face-specific experiments, see text in section 2.2.3. for further details.

Table 2: VSI, SEM and TEM measurements on dissolved labradorite samples. Global surface retreats and associated uncertainties $(\sigma)$ are reported in the table. Values for layer thickness and associated uncertainties $(\sigma)$ were estimated from SEM and TEM measurements. 
Fig. 1.

A.

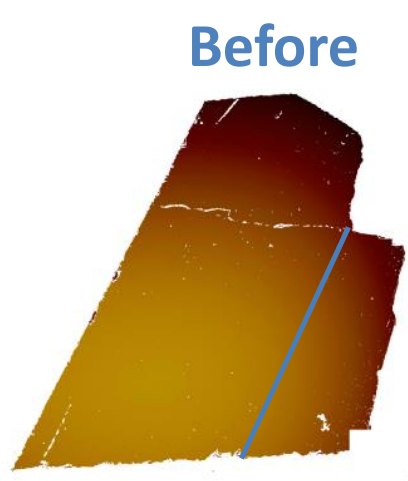

B.

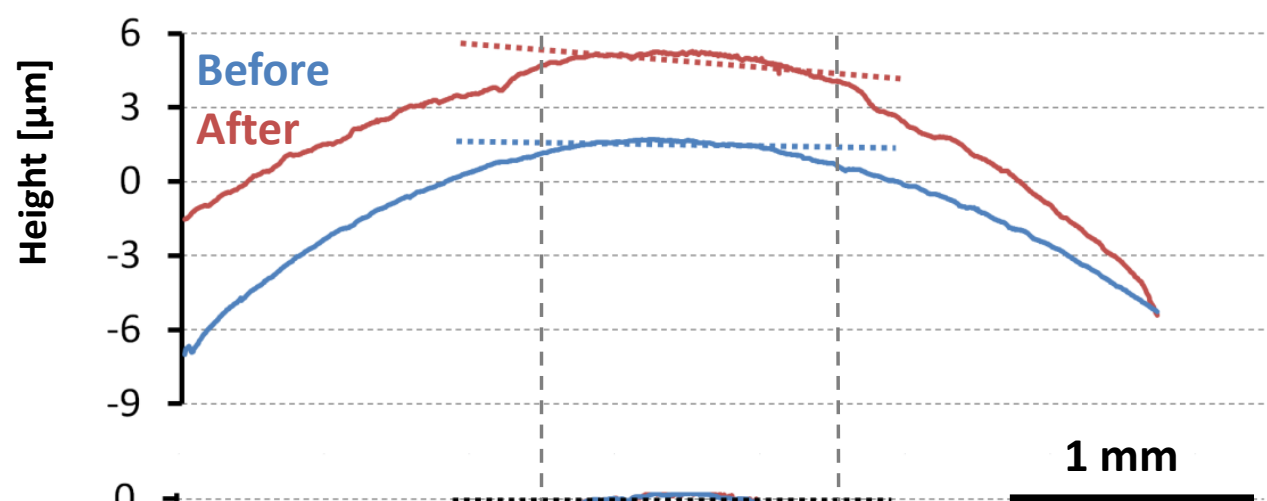

C.

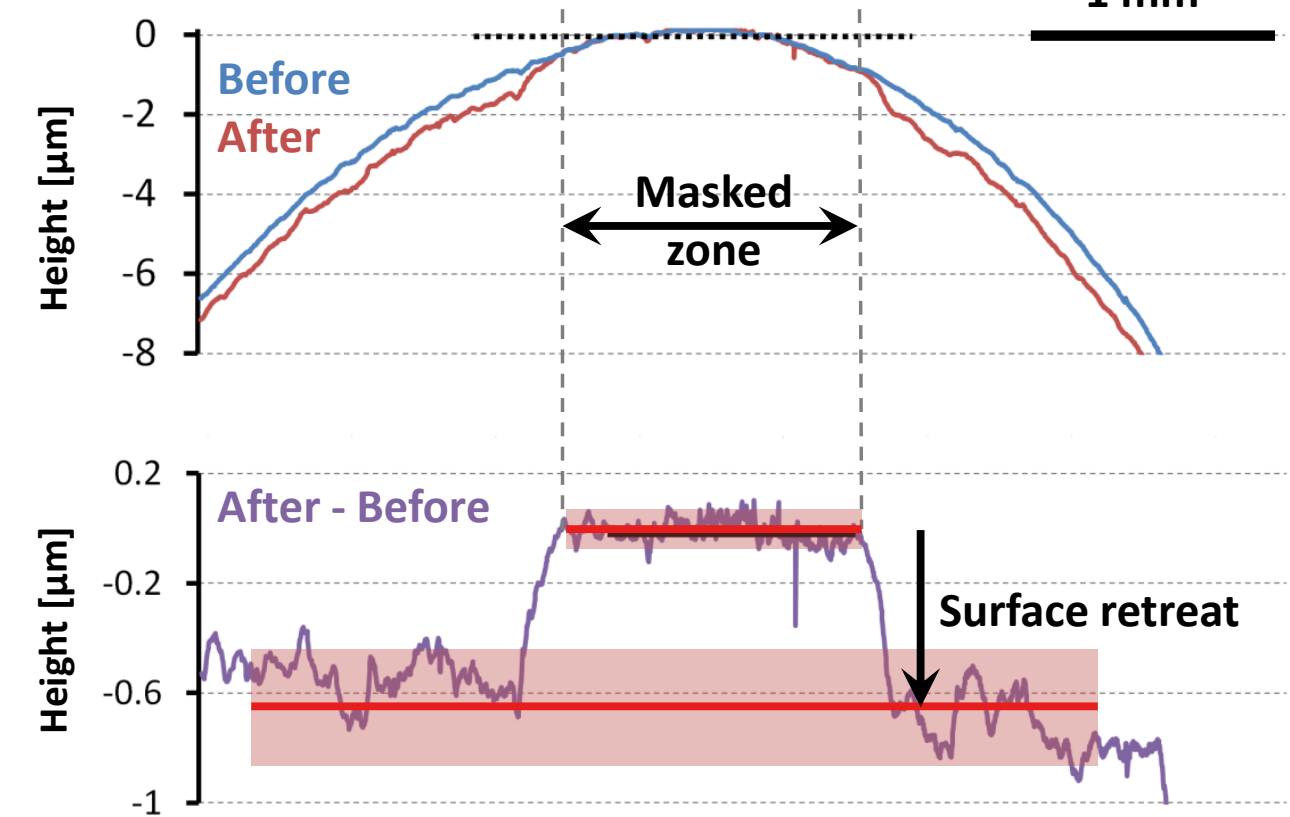


Fig. 2.

A.

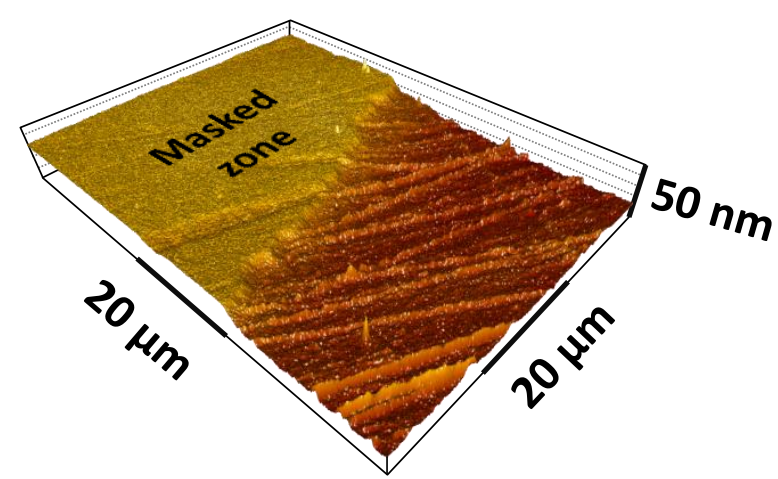

c.

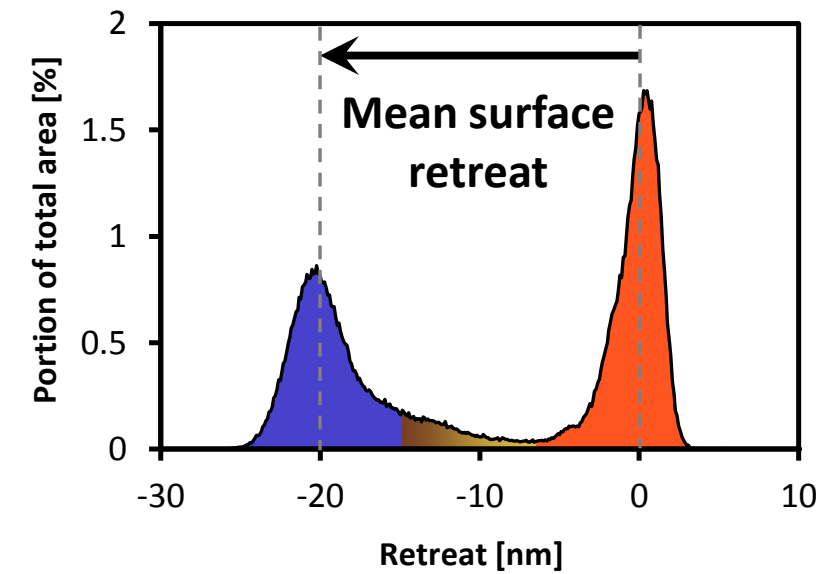

B.

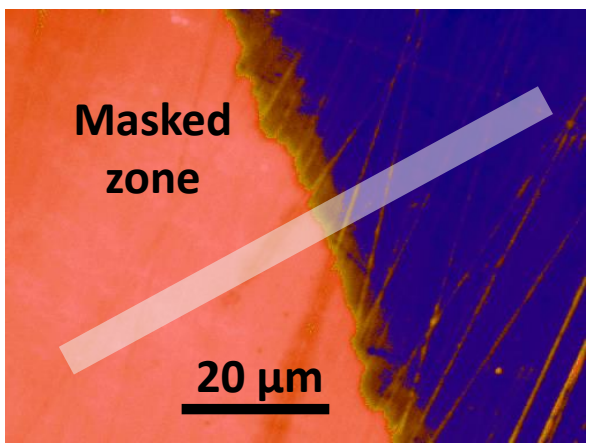

D.

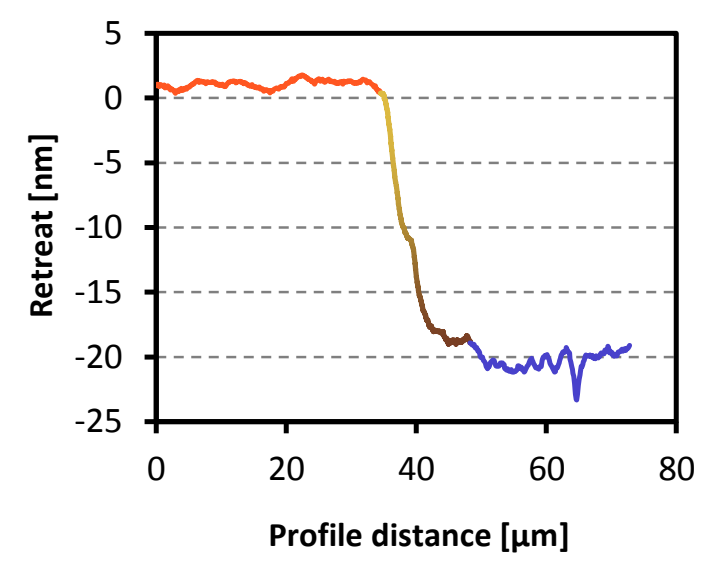




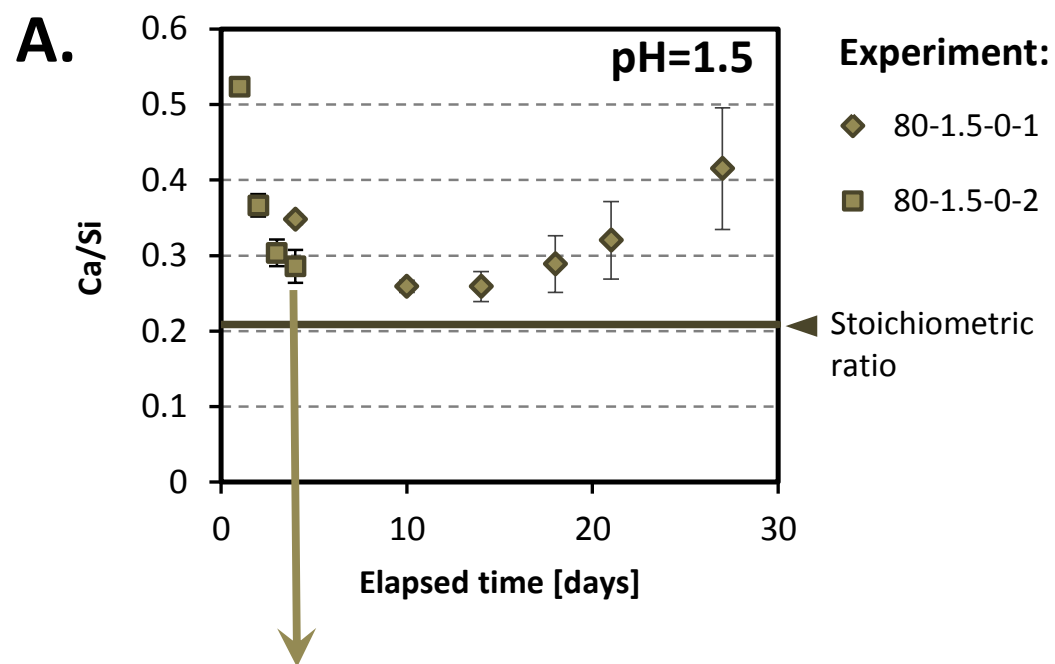

B.

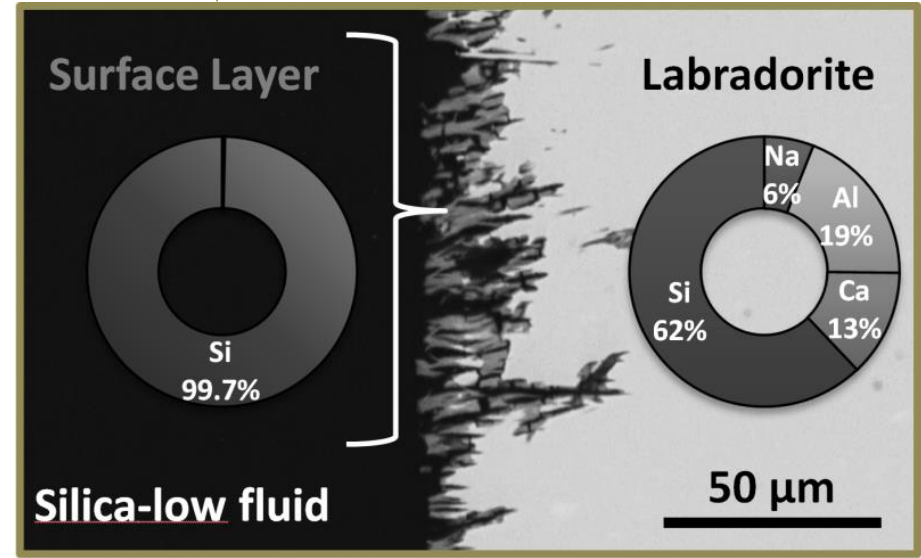

C.

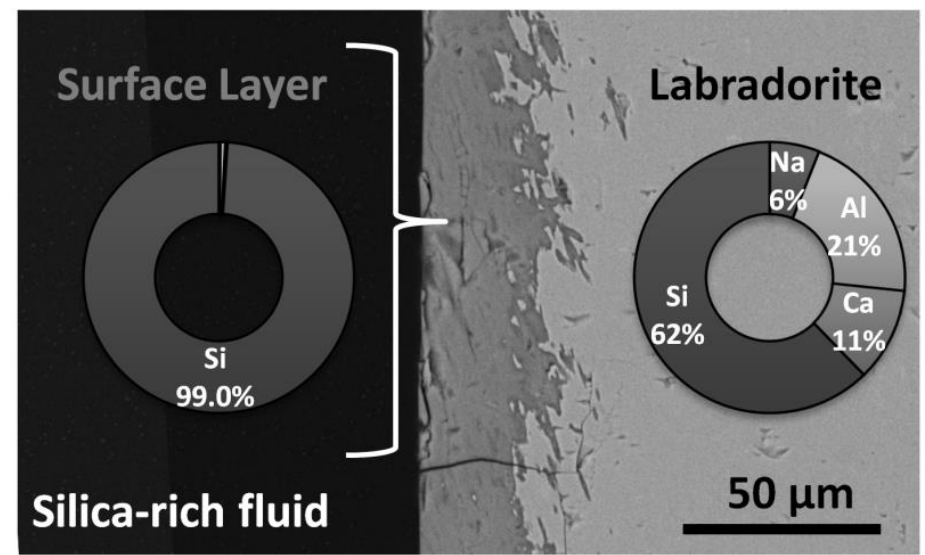


Fig. 4.

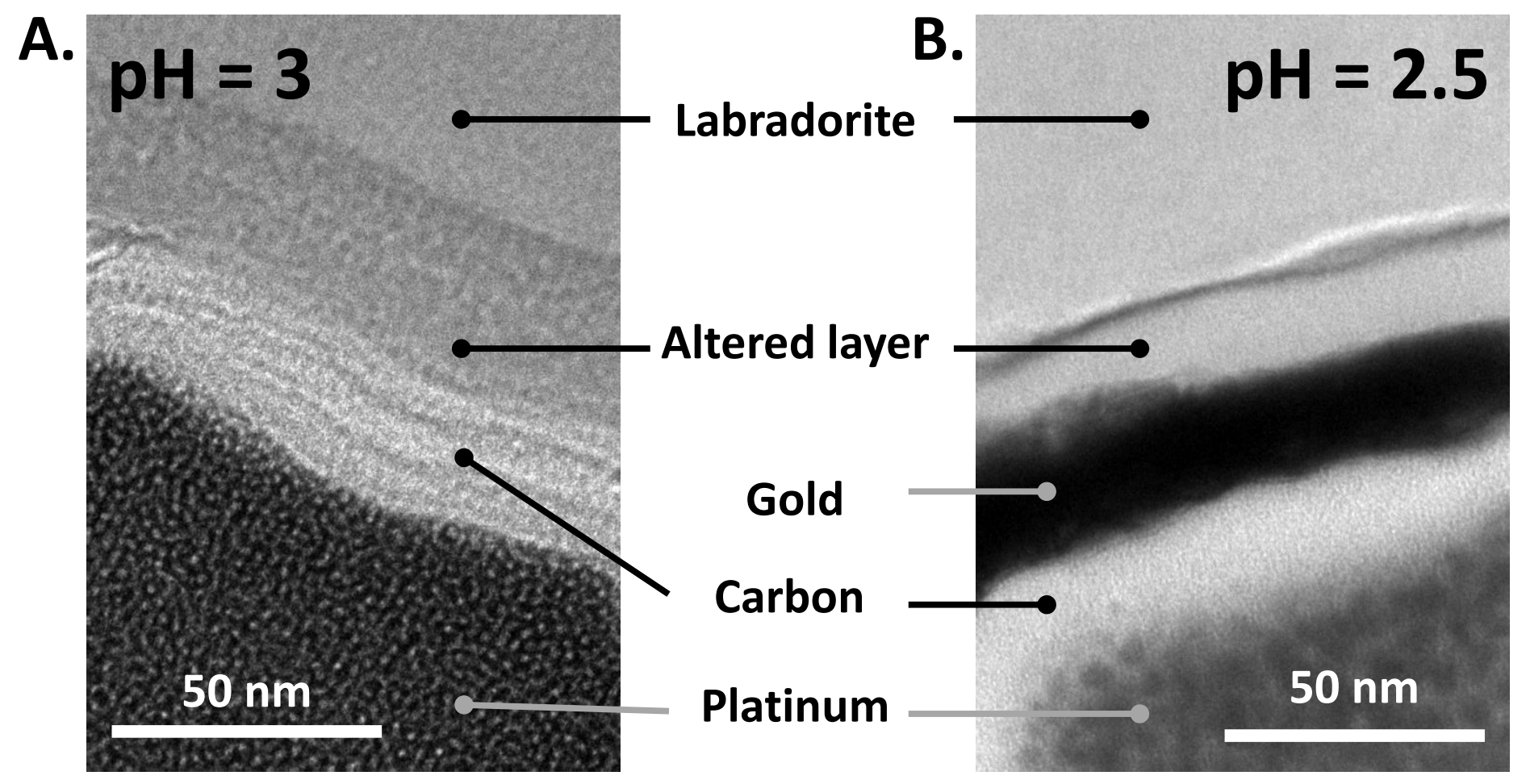


Fig. 5.

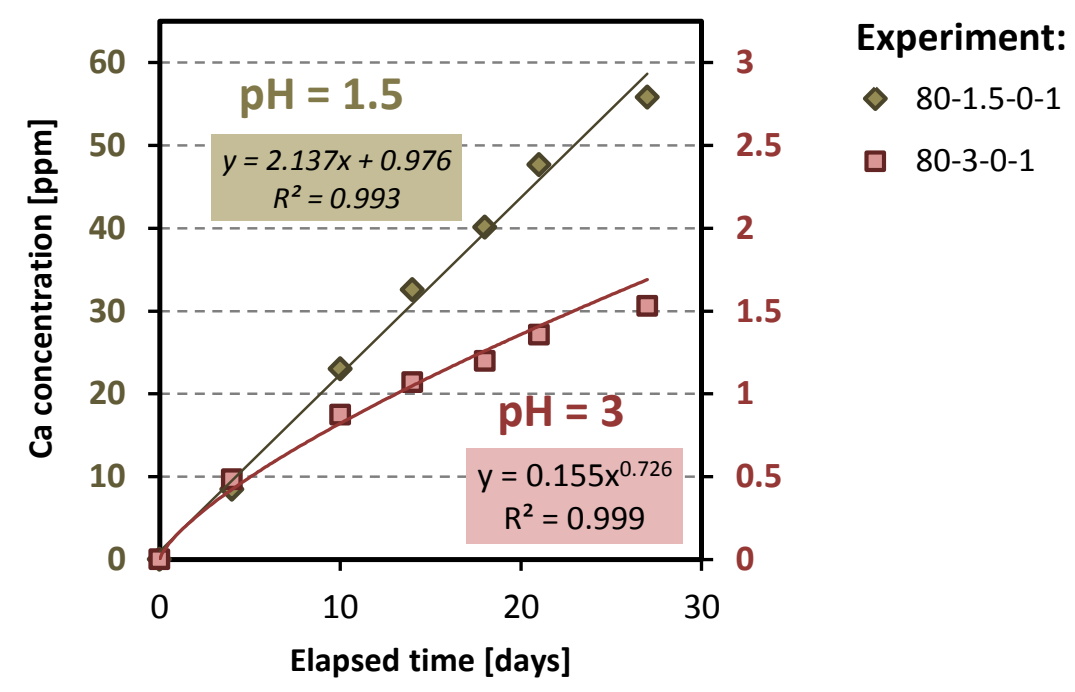


Fig. 6.
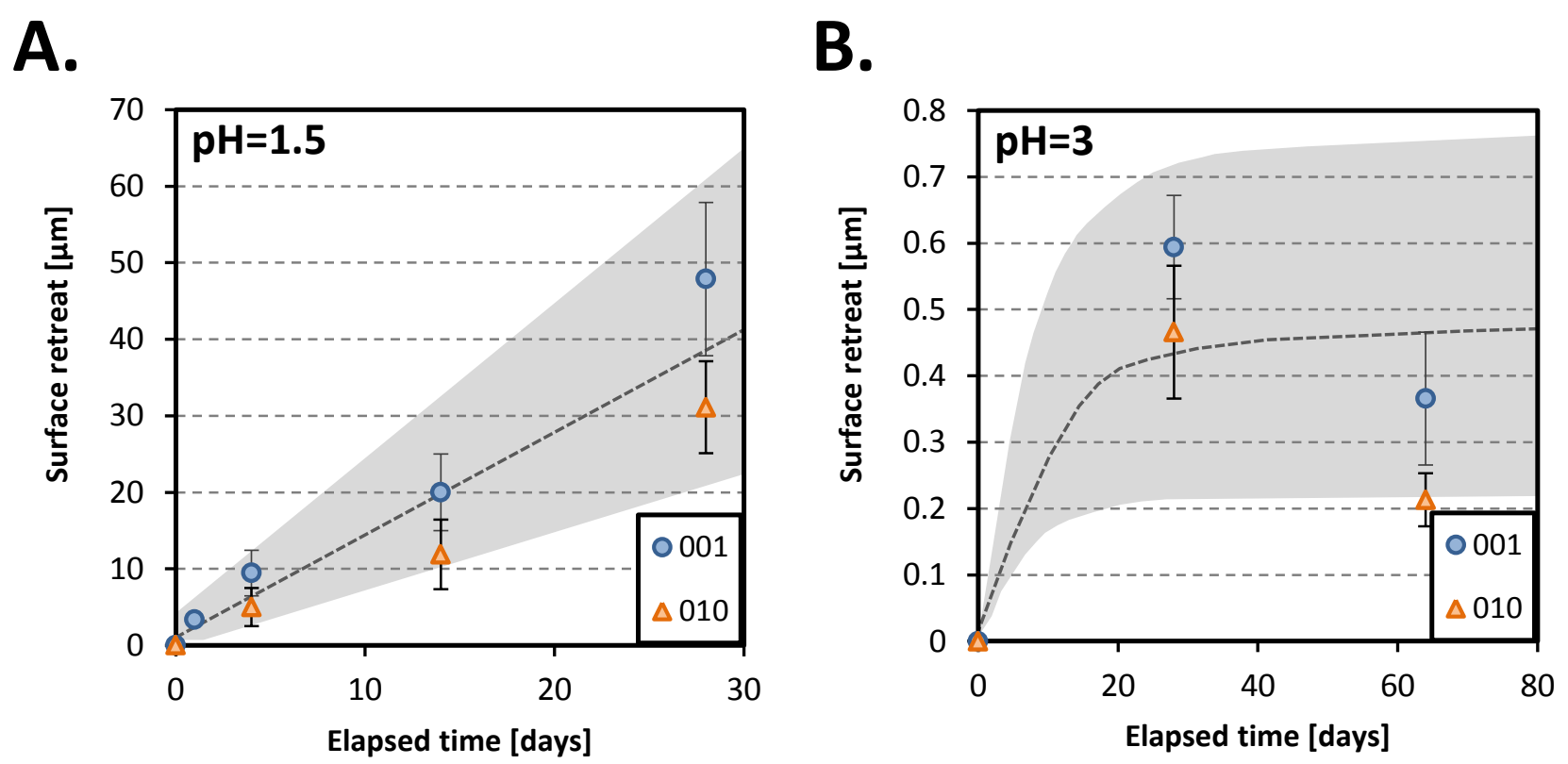

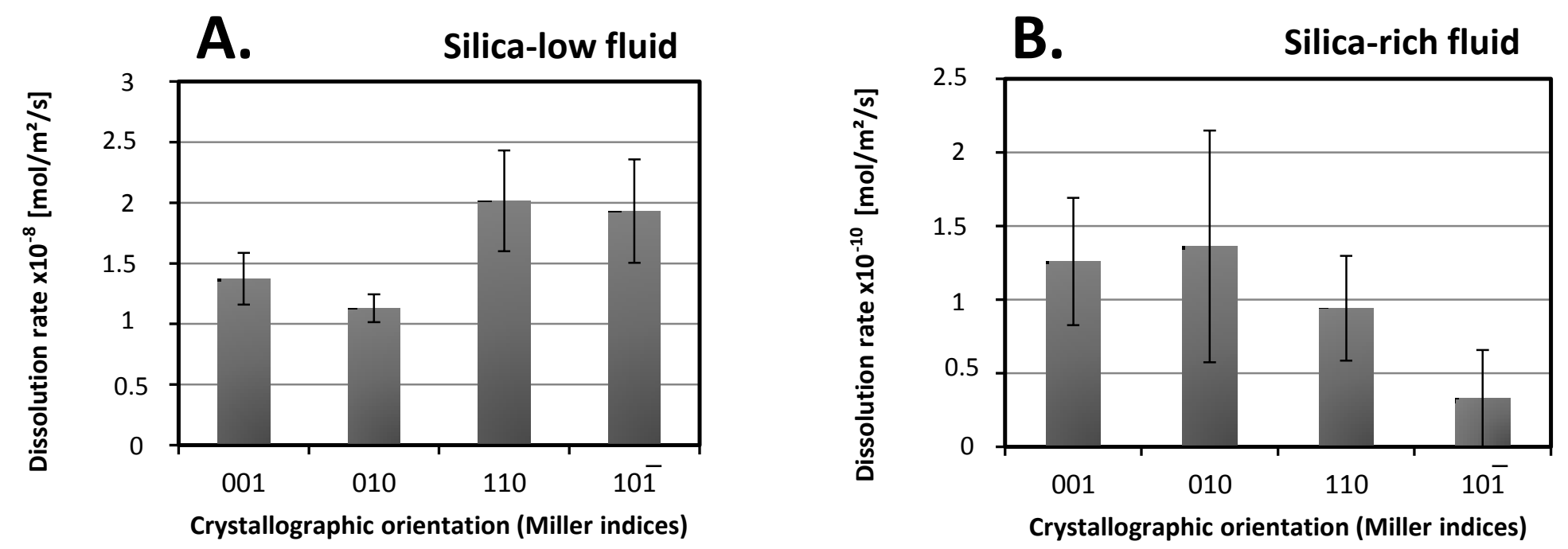
Fig. 8.
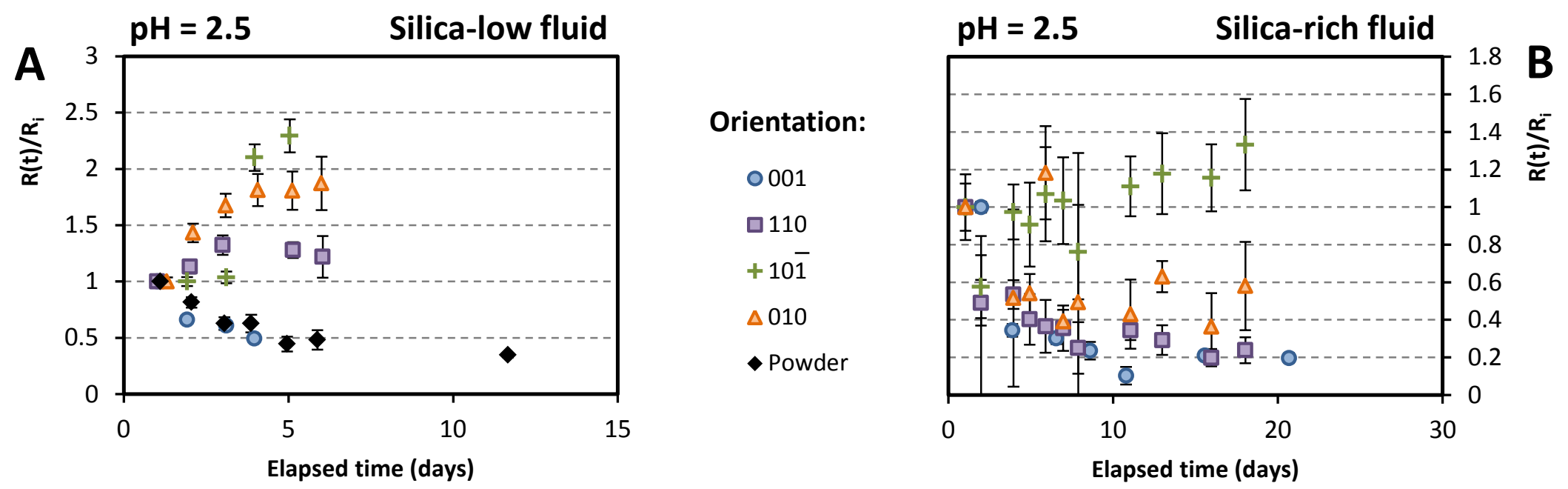

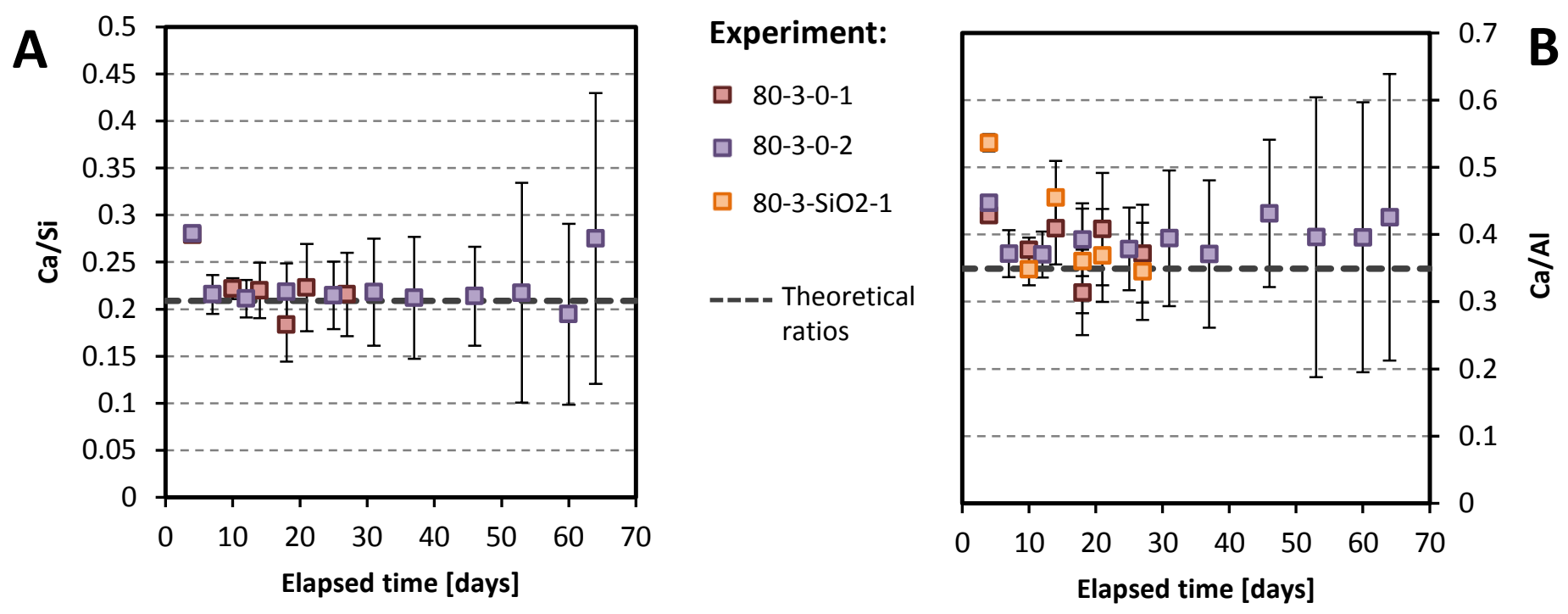
Fig. 10.

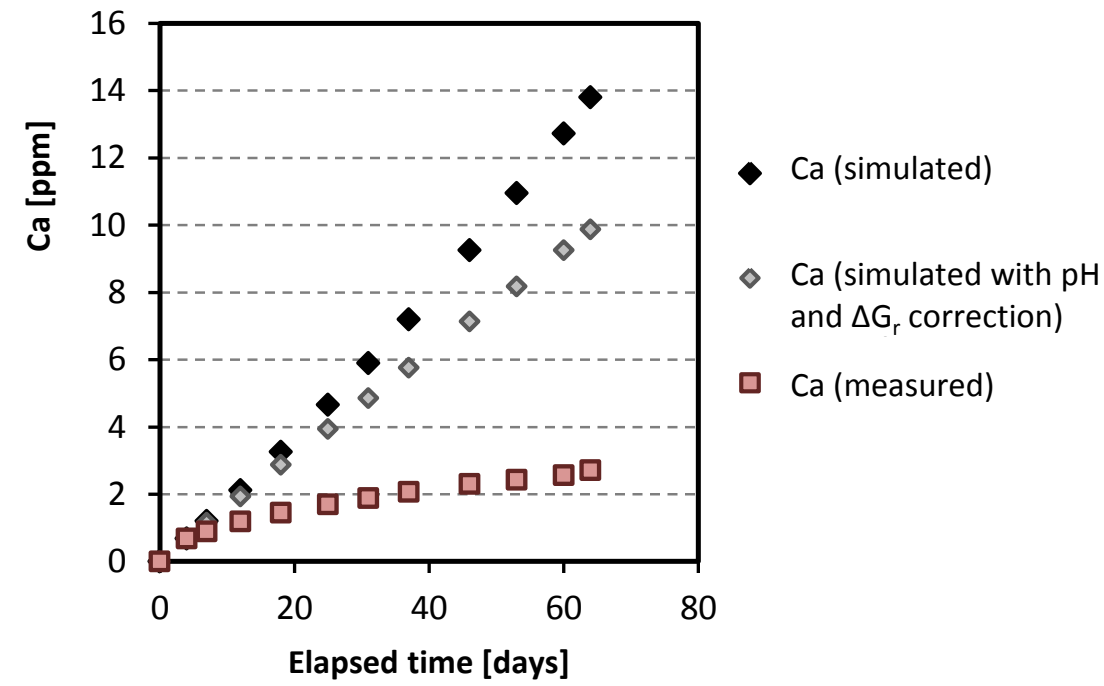


Fig. 11.

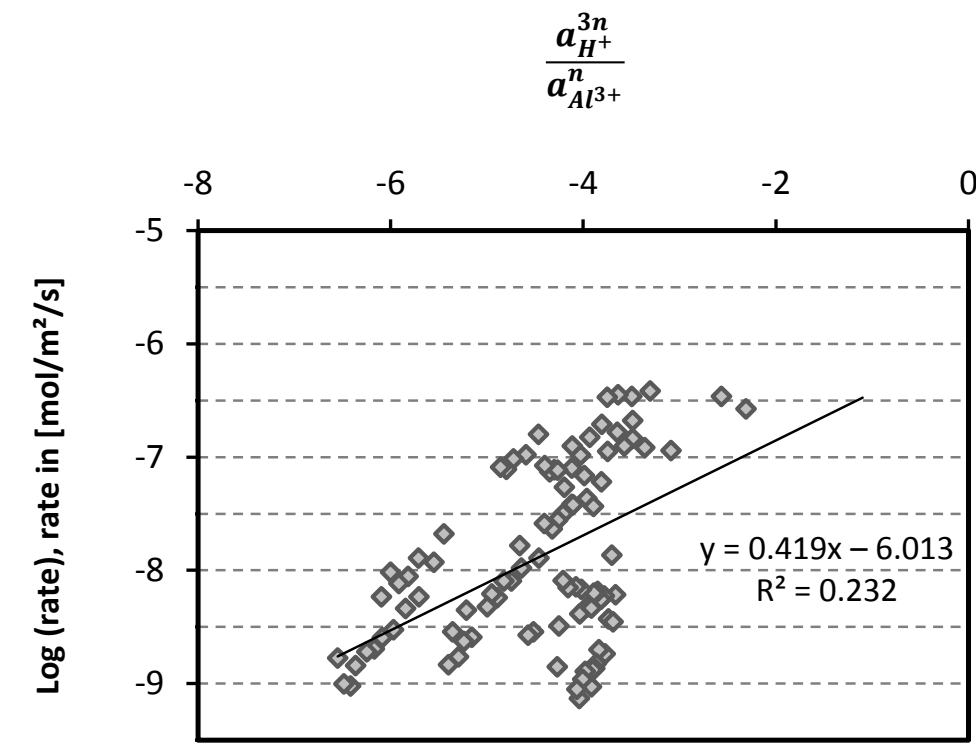


Fig. 12.
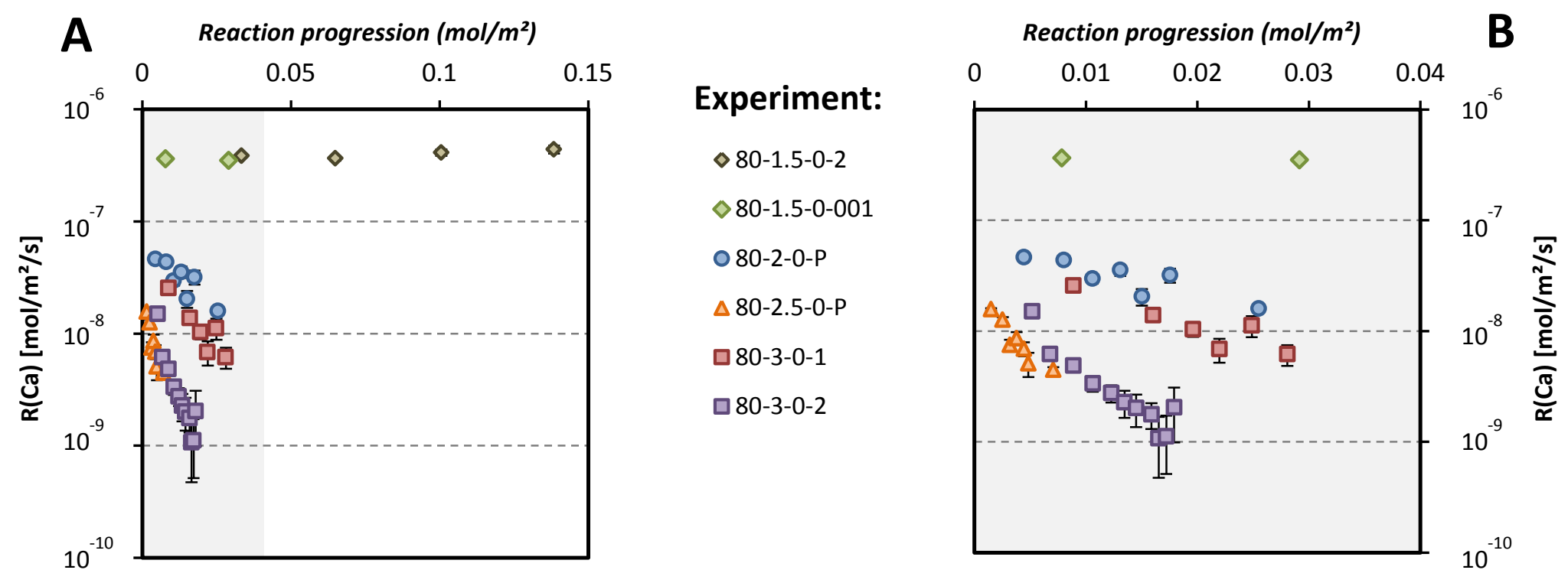
Fig. 13.
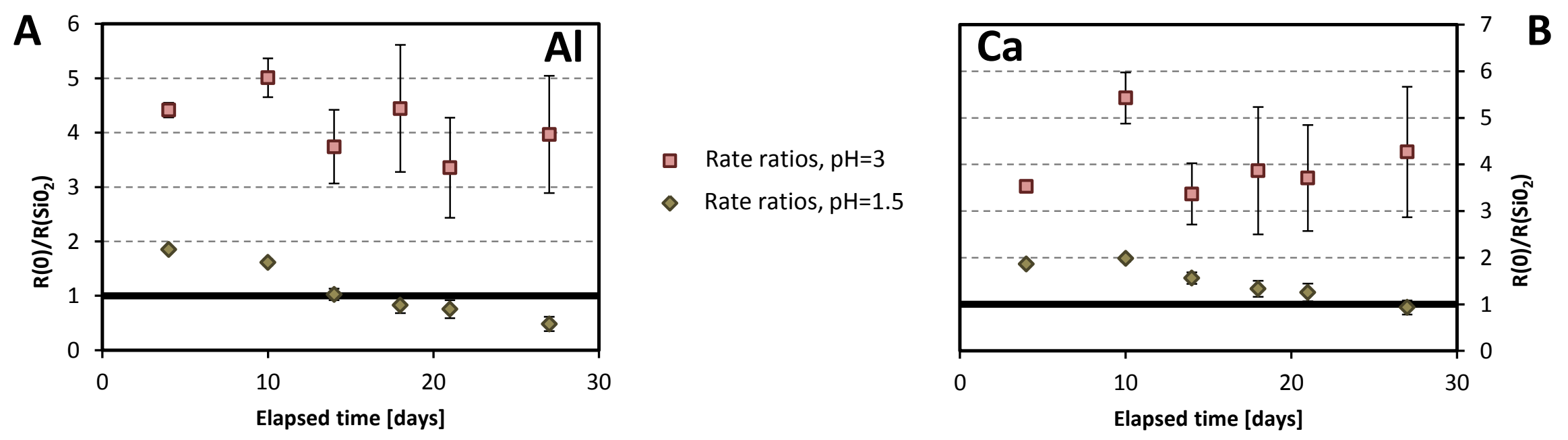

- Rate ratios, $\mathrm{pH}=3$

$\checkmark$ Rate ratios, $\mathrm{pH}=1.5$

Elapsed time [days] 
TABLE 1

\begin{tabular}{|c|c|c|c|c|c|c|c|}
\hline \multirow{2}{*}{\multicolumn{2}{|c|}{$\mathbf{T}=80^{\circ} \mathrm{C}$}} & \multicolumn{6}{|c|}{ Fluid } \\
\hline & & \multicolumn{2}{|c|}{$\mathrm{pH}=1.5$} & \multicolumn{2}{|c|}{$\mathrm{pH}=2.5$} & \multicolumn{2}{|c|}{$\mathbf{p H}=3$} \\
\hline \multirow{5}{*}{ 䒕 } & $\begin{array}{c}\text { Saturation } \\
\text { Orientation }\end{array}$ & $\mathrm{SiO}_{2(\mathrm{am})}$ & none & $\mathrm{SiO}_{2(\mathrm{am})}$ & none & $\mathrm{SiO}_{2(\mathrm{am})}$ & none \\
\hline & (001) & $\begin{array}{l}80-1.5-\mathrm{SiO} 2-1 \\
80-1.5-\mathrm{SiO} 2-2\end{array}$ & $\begin{array}{l}80-1.5-0-1 \\
80-1.5-0-2 \\
80-1.5-0-3 \\
80-1.5-0-4\end{array}$ & 80-2.5-SiO2-001* & $\begin{array}{c}80-2.5-0-001 * \\
80-2.5-0-001-2^{*}\end{array}$ & & $\begin{array}{l}80-3-0-1 \\
80-3-0-2\end{array}$ \\
\hline & (010) & & $\begin{array}{l}80-1.5-0-1 \\
80-1.5-0-2 \\
80-1.5-0-4\end{array}$ & $80-2.5-\mathrm{SiO} 2-010^{*}$ & $80-2.5-0-010^{*}$ & 80-3-SiO2-1 & $\begin{array}{l}80-3-0-1 \\
80-3-0-2\end{array}$ \\
\hline & $(\mathbf{1 0} \overline{\mathbf{1}})$ & & & $80-2.5-\mathrm{SiO} 2-10 \overline{1} *$ & $80-2.5-0-10 \overline{1}^{*}$ & & \\
\hline & (110) & & & 80-2.5-SiO2-110* & $80-2.5-0-110 *$ & & \\
\hline
\end{tabular}


TABLE 2

\begin{tabular}{|c|c|c|c|c|c|c|c|c|c|}
\hline \multicolumn{10}{|c|}{$[\mathrm{SiO} 2](\mathrm{t}=0)=0 \mathrm{M}$} \\
\hline Sample & $\begin{array}{c}\text { Orientation } \\
\text { [Miller Indices] }\end{array}$ & pH & $\begin{array}{c}\text { time } \\
\text { [days] }\end{array}$ & $\begin{array}{c}\text { Retreat } \\
{[\mu \mathrm{m}]}\end{array}$ & $\begin{array}{c}\sigma(\text { Retreat }) \\
{[\mu \mathrm{m}]}\end{array}$ & $\begin{array}{c}\text { Layer thickness } \\
{[\mu \mu \mathrm{m}]}\end{array}$ & $\begin{array}{c}\sigma(\text { layer thickness) } \\
{[\mu \mathrm{m}]}\end{array}$ & $\begin{array}{l}\text { Rate }(\mathbf{e x t}) \\
{\left[\mathrm{mol} / \mathbf{m}^{2} / \mathbf{s}\right]}\end{array}$ & $\begin{array}{c}\sigma(\text { Rate }) \\
{\left[\mathrm{mol} / \mathrm{m}^{2} / \mathrm{s}\right]}\end{array}$ \\
\hline $80-1.5-0-1-001$ & 001 & 1.5 & 28.0 & 47.9 & 10.0 & 26.3 & 6.1 & $2.0 \mathrm{E}-07$ & $4.2 \mathrm{E}-08$ \\
\hline $80-1.5-0-1-010$ & 010 & 1.5 & 28.0 & 31.1 & 6.0 & 18.5 & 13.8 & $1.3 \mathrm{E}-07$ & $2.5 \mathrm{E}-08$ \\
\hline $80-1.5-0-2-001$ & 001 & 1.5 & 4.0 & 9.5 & 3.0 & 7.1 & 3.8 & $2.8 \mathrm{E}-07$ & 8.9E-08 \\
\hline $80-1.5-0-2-010$ & 010 & 1.5 & 4.0 & 5.0 & 2.5 & 14.3 & 2.5 & $1.5 \mathrm{E}-07$ & 7.4E-08 \\
\hline $80-1.5-0-3-001$ & 001 & 1.5 & 1.0 & 3.4 & 0.3 & ND & ND & $4.0 \mathrm{E}-07$ & $3.6 \mathrm{E}-08$ \\
\hline $80-1.5-0-4-001$ & 001 & 1.5 & 14.0 & 20.0 & 5.0 & ND & ND & $1.7 \mathrm{E}-07$ & 4.2E-08 \\
\hline $80-1.5-0-4-010$ & 010 & 1.5 & 14.0 & 11.9 & 4.5 & ND & ND & $1.0 \mathrm{E}-07$ & $3.8 \mathrm{E}-08$ \\
\hline 80-2.5-0-001 & 001 & 2.5 & 5.0 & 0.583 & 0.091 & ND & ND & $1.4 \mathrm{E}-08$ & 2.1E-09 \\
\hline $80-2.5-0-001-2$ & 001 & 2.5 & 12.0 & ND & ND & 0.014 & 0.002 & ND & ND \\
\hline $80-2.5-0-010$ & 010 & 2.5 & 6.0 & 0.572 & 0.058 & ND & ND & $1.1 \mathrm{E}-08$ & $1.1 \mathrm{E}-09$ \\
\hline $80-2.5-0-110$ & 110 & 2.5 & 6.0 & 1.026 & 0.212 & ND & ND & $2.0 \mathrm{E}-08$ & 4.2E-09 \\
\hline $80-2.5-0-10 \overline{1}$ & $10 \overline{1}$ & 2.5 & 5.0 & 0.820 & 0.181 & ND & ND & $1.9 \mathrm{E}-08$ & 4.3E-09 \\
\hline $80-3-0-1-001$ & 001 & 3 & 28.0 & 0.594 & 0.078 & 0.027 & 0.001 & $2.5 \mathrm{E}-09$ & $3.3 \mathrm{E}-10$ \\
\hline $80-3-0-1-010$ & 010 & 3 & 28.0 & 0.466 & 0.100 & ND & ND & $2.0 \mathrm{E}-09$ & $4.2 \mathrm{E}-10$ \\
\hline $80-3-0-2-001$ & 001 & 3 & 64.0 & 0.366 & 0.100 & 0.026 & 0.005 & $6.8 \mathrm{E}-10$ & $1.9 \mathrm{E}-10$ \\
\hline $80-3-0-2-010$ & 010 & 3 & 64.0 & 0.213 & 0.040 & ND & $\mathrm{ND}$ & $4.0 \mathrm{E}-10$ & 7.4E-11 \\
\hline \multicolumn{10}{|c|}{$[\mathrm{SiO} 2](\mathrm{t}=0)=5.2 \mathrm{E}-3 \mathrm{M}$} \\
\hline Sample & $\begin{array}{c}\text { Orientation } \\
\text { [Miller Indices] }\end{array}$ & pH & $\begin{array}{l}\text { time } \\
\text { [days] }\end{array}$ & $\begin{array}{c}\text { Retreat } \\
{[\mu \mathrm{m}]}\end{array}$ & $\begin{array}{c}\sigma(\text { Retreat) } \\
{[\mu \mathrm{m}]}\end{array}$ & $\begin{array}{c}\text { Layer thickness } \\
{[\mu \mathrm{m}]}\end{array}$ & $\begin{array}{c}\sigma \text { (layer thickness) } \\
{[\mu \mathrm{m}]}\end{array}$ & $\begin{array}{l}\text { Rate }(\text { ext) } \\
{\left[\mathrm{mol} / \mathrm{m}^{2} / \mathrm{s}\right]}\end{array}$ & $\begin{array}{c}\sigma(\text { Rate }) \\
{\left[\mathrm{mol} / \mathrm{m}^{2} / \mathrm{s}\right]}\end{array}$ \\
\hline $80-1.5-\mathrm{SiO}_{2}-2-001$ & 001 & 1.5 & 60.0 & 0.638 & 0.150 & 47.740 & 11.290 & $1.3 \mathrm{E}-09$ & $3.0 \mathrm{E}-10$ \\
\hline $80-2.5-\mathrm{SiO}_{2}-001$ & 001 & 2.5 & 20.7 & 0.022 & 0.008 & ND & ND & $1.3 \mathrm{E}-10$ & $4.3 \mathrm{E}-11$ \\
\hline $80-2.5-\mathrm{SiO}_{2}-001-2$ & 001 & 2.5 & 20.0 & $\mathrm{ND}$ & $\mathrm{ND}$ & 0.010 & 0.003 & ND & $\mathrm{ND}$ \\
\hline $80-2.5-\mathrm{SiO}_{2}-010$ & 010 & 2.5 & 18.0 & 0.021 & 0.012 & ND & $\mathrm{ND}$ & $1.4 \mathrm{E}-10$ & 7.9E-11 \\
\hline $80-2.5-\mathrm{SiO}_{2}-110$ & 110 & 2.5 & 18.0 & 0.014 & 0.005 & ND & ND & $9.4 \mathrm{E}-11$ & $3.6 \mathrm{E}-11$ \\
\hline $80-2.5-\mathrm{SiO}_{2}-10 \overline{1}$ & $10 \overline{1}$ & 2.5 & 18.0 & 0.005 & 0.005 & $\mathrm{ND}$ & $\mathrm{ND}$ & 3.3E-11 & $3.3 \mathrm{E}-11$ \\
\hline $80-3-\mathrm{SiO}_{2}-1-010$ & 010 & 3 & 28.0 & 0.010 & 0.004 & 0.057 & 0.006 & $4.2 \mathrm{E}-11$ & $1.7 \mathrm{E}-11$ \\
\hline
\end{tabular}


1 TABLE A.1

"80-1.5-0-1": $\mathrm{T}=80^{\circ} \mathrm{C}, \mathrm{pH}=1.5,[\mathrm{SiO} 2](\mathrm{t}=0)=0 \mathrm{M}$, multiple orientations, $\Delta \mathrm{Gr}$ (final) $=.91 .74 \mathrm{~kJ} / \mathrm{mol}$

\begin{tabular}{|c|c|c|c|c|c|c|c|c|c|c|c|c|c|c|}
\hline $\begin{array}{c}\mathrm{Si} \\
{[\mathrm{ppm}]}\end{array}$ & $\begin{array}{c}\text { Al } \\
{[\text { ppm] }}\end{array}$ & $\begin{array}{c}\text { Ca } \\
{[\mathrm{ppm}]}\end{array}$ & $\begin{array}{c}\mathrm{Na} \\
{[\mathrm{ppm}]}\end{array}$ & $\begin{array}{l}\text { time } \\
\text { [days] }\end{array}$ & $\begin{array}{c}\text { Fluid mass } \\
{[\mathrm{g}]}\end{array}$ & $\begin{array}{c}\text { Surface } \\
{\left[\mathbf{m}^{2}\right]}\end{array}$ & $\begin{array}{c}\text { Rate (Si) } \\
{\left[\mathbf{m o l} / \mathbf{m}^{2} / \mathbf{s}\right]}\end{array}$ & $\begin{array}{c}\text { Rate (Al) } \\
{\left[\mathrm{mol} / \mathrm{m}^{2} / \mathrm{s}\right]}\end{array}$ & $\begin{array}{l}\text { Rate (Ca) } \\
{\left[\mathrm{mol} / \mathbf{m}^{2} / \mathbf{s}\right]}\end{array}$ & $\begin{array}{l}\text { Rate (Na) } \\
{\left[\mathrm{mol} / \mathbf{m}^{2} / \mathrm{s}\right]}\end{array}$ & $\begin{array}{c}\zeta(\mathrm{Al}) \\
{\left[\mathbf{m o l} / \mathbf{m}^{2}\right]}\end{array}$ & $\begin{array}{c}\zeta(\mathbf{C a}) \\
{\left[\mathbf{m o l} / \mathbf{m}^{2}\right]}\end{array}$ & $\begin{array}{c}\mathbf{p H} \\
\text { (sim.) }\end{array}$ & $\begin{array}{l}\text { Phases } \\
\text { with SI>0 }\end{array}$ \\
\hline 0.12 & 0.02 & 0.11 & 0.20 & 0.0 & 110.42 & $6.00 \mathrm{E}-04$ & & & & & 0 & 0 & 1.5 & - \\
\hline 17.8 & 16.4 & 8.89 & 4.10 & 4.0 & 106.71 & $6.00 \mathrm{E}-04$ & 2.17E-07 & $2.10 \mathrm{E}-07$ & $2.17 \mathrm{E}-07$ & $1.68 \mathrm{E}-07$ & $7.26 \mathrm{E}-02$ & 7.49E-02 & 1.53 & \\
\hline 60 & 40.0 & 24.5 & 11.7 & 10.0 & 103.00 & $6.00 \mathrm{E}-04$ & 3.33E-07 & $1.94 \mathrm{E}-07$ & $2.47 \mathrm{E}-07$ & $2.09 \mathrm{E}-07$ & $1.73 \mathrm{E}-01$ & $2.03 \mathrm{E}-01$ & 1.58 & Qz, Trd, Chal, Crs(alpha) \\
\hline 89 & 52.6 & 35.1 & 17.1 & 14.0 & 99.29 & $6.00 \mathrm{E}-04$ & $3.29 \mathrm{E}-07$ & $1.49 \mathrm{E}-07$ & $2.45 \mathrm{E}-07$ & $2.19 \mathrm{E}-07$ & $2.25 \mathrm{E}-01$ & $2.88 \mathrm{E}-01$ & 1.61 & Qz, Trd, Chal, Crs(alpha), Coe \\
\hline 110 & 61.6 & 43.8 & 20.9 & 18.0 & 95.58 & $6.00 \mathrm{E}-04$ & 2.33E-07 & $1.04 \mathrm{E}-07$ & $1.93 \mathrm{E}-07$ & $1.45 \mathrm{E}-07$ & $2.61 \mathrm{E}-01$ & $3.54 \mathrm{E}-01$ & 1.64 & Qz, Trd, Chal, Crs(alpha), Coe, Crs(beta) \\
\hline 130 & 70.1 & 52.9 & 25.7 & 21.0 & 92.07 & $6.00 \mathrm{E}-04$ & $2.80 \mathrm{E}-07$ & $1.25 \mathrm{E}-07$ & $2.57 \mathrm{E}-07$ & $2.36 \mathrm{E}-07$ & $2.93 \mathrm{E}-01$ & $4.21 \mathrm{E}-01$ & 1.67 & Qz, Trd, Chal, Crs(alpha), Coe, Crs(beta) \\
\hline 147 & 77.8 & 63.1 & 30.5 & 27.0 & 87.88 & $6.00 \mathrm{E}-04$ & $1.17 \mathrm{E}-07$ & $5.40 \mathrm{E}-08$ & $1.39 \mathrm{E}-07$ & $1.15 \mathrm{E}-07$ & $3.21 \mathrm{E}-01$ & 4.93E-01 & 1.7 & Qz, Trd, Chal, Crs(alpha), Coe, $\mathrm{Crs}(\mathrm{beta}), \mathrm{SiO} 2$ (am) \\
\hline \multicolumn{15}{|c|}{ "80-1.5-0-2": $\mathrm{T}=80^{\circ} \mathrm{C}, \mathrm{pH}=1.5,[\mathrm{SiO} 2](\mathrm{t}=0)=0 \mathrm{M}$, multiple orientations, $\Delta \mathrm{Gr}$ (final) $=-112.70 \mathrm{~kJ} / \mathrm{mol}$} \\
\hline $\begin{array}{c}\mathrm{Si} \\
{[\mathrm{ppm}]}\end{array}$ & $\begin{array}{c}\text { Al } \\
{[\text { ppm] }}\end{array}$ & $\begin{array}{c}\text { Ca } \\
{[\mathrm{ppm}]}\end{array}$ & $\begin{array}{c}\mathrm{Na} \\
{[\mathrm{ppm}]}\end{array}$ & $\begin{array}{l}\text { time } \\
\text { [days] }\end{array}$ & $\begin{array}{l}\text { Fluid mass } \\
{[\mathrm{g}]}\end{array}$ & $\begin{array}{l}\text { Surface } \\
{\left[\mathrm{m}^{2}\right]}\end{array}$ & $\begin{array}{c}\text { Rate (Si) } \\
{\left[\mathrm{mol} / \mathrm{m}^{2} / \mathrm{s}\right]}\end{array}$ & $\begin{array}{c}\text { Rate (Al) } \\
{\left[\mathrm{mol} / \mathrm{m}^{2} / \mathrm{s}\right]}\end{array}$ & $\begin{array}{l}\text { Rate (Ca) } \\
{\left[\mathrm{mol} / \mathrm{m}^{2} / \mathrm{s}\right]}\end{array}$ & $\begin{array}{l}\text { Rate (Na) } \\
{\left[\mathrm{mol} / \mathrm{m}^{2} / \mathrm{s}\right]}\end{array}$ & $\begin{array}{c}\zeta(\mathbf{A l}) \\
{\left[\mathbf{m o l} / \mathbf{m}^{2}\right]}\end{array}$ & $\begin{array}{c}\zeta(\mathbf{C a}) \\
{\left[\mathbf{m o l} / \mathbf{m}^{2}\right]}\end{array}$ & $\begin{array}{c}\mathrm{pH} \\
\text { (sim.) }\end{array}$ & $\begin{array}{l}\text { Phases } \\
\text { with SI>0 }\end{array}$ \\
\hline 0.08 & 0.10 & 0.05 & 0.13 & 0.0 & 102.00 & $6.50 \mathrm{E}-04$ & & & & & $0.00 \mathrm{E}+00$ & $0.00 \mathrm{E}+00$ & 1.5 & - \\
\hline 6.24 & 8.87 & 4.65 & 2.00 & 1.0 & 98.31 & $6.50 \mathrm{E}-04$ & $2.58 \mathrm{E}-07$ & $3.82 \mathrm{E}-07$ & 3.86E-07 & 2.73E-07 & $3.30 \mathrm{E}-02$ & $3.34 \mathrm{E}-02$ & 1.52 & - \\
\hline 14.9 & 17.1 & 9.20 & 3.93 & 2.0 & 94.23 & $6.50 \mathrm{E}-04$ & 3.48E-07 & $3.42 \mathrm{E}-07$ & 3.66E-07 & 2.71E-07 & $6.25 \mathrm{E}-02$ & $6.50 \mathrm{E}-02$ & 1.53 & - \\
\hline 27.2 & 25.9 & 14.5 & 6.31 & 3.0 & 90.60 & $6.50 \mathrm{E}-04$ & 4.73E-07 & $3.53 \mathrm{E}-07$ & 4.12E-07 & $3.20 \mathrm{E}-07$ & $9.30 \mathrm{E}-02$ & $1.01 \mathrm{E}-01$ & 1.55 & Qz, Trd, Chal \\
\hline 41.8 & 34.7 & 20.5 & 8.97 & 4.0 & 86.65 & $6.50 \mathrm{E}-04$ & $5.36 \mathrm{E}-07$ & $3.38 \mathrm{E}-07$ & $4.39 \mathrm{E}-07$ & $3.44 \mathrm{E}-07$ & $1.22 \mathrm{E}-01$ & $1.38 \mathrm{E}-01$ & 1.57 & Qz, Trd, Chal \\
\hline \multicolumn{15}{|c|}{ "80-1.5-0-001": $\mathrm{T}=80^{\circ} \mathrm{C}, \mathrm{pH}=1.5,[\mathrm{SiO2}](\mathrm{t}=0)=0 \mathrm{M},(001)$ orientation, $\Delta \mathrm{Gr}$ (final) $=-178.75 \mathrm{~kJ} / \mathrm{mol}$} \\
\hline $\begin{array}{c}\mathrm{Si} \\
{[\mathrm{ppm}]}\end{array}$ & $\begin{array}{c}\text { Al } \\
{[\mathbf{p p m}]}\end{array}$ & $\begin{array}{c}\text { Ca } \\
{[\mathrm{ppm}]}\end{array}$ & $\begin{array}{c}\mathrm{Na} \\
{[\mathrm{ppm}]}\end{array}$ & $\begin{array}{l}\text { time } \\
\text { [days] }\end{array}$ & $\begin{array}{c}\text { Fluid mass } \\
{[\mathrm{g}]}\end{array}$ & $\begin{array}{l}\text { Surface } \\
{\left[\mathrm{m}^{2}\right]}\end{array}$ & $\begin{array}{c}\text { Rate (Si) } \\
{\left[\mathrm{mol} / \mathrm{m}^{2} / \mathrm{s}\right]}\end{array}$ & $\begin{array}{c}\text { Rate (Al) } \\
{\left[\mathrm{mol} / \mathbf{m}^{2} / \mathrm{s}\right]}\end{array}$ & $\begin{array}{l}\text { Rate (Ca) } \\
{\left[\mathrm{mol} / \mathrm{m}^{2} / \mathrm{s}\right]}\end{array}$ & $\begin{array}{l}\text { Rate }(\mathrm{Na}) \\
{\left[\mathrm{mol} / \mathrm{m}^{2} / \mathrm{s}\right]}\end{array}$ & $\begin{array}{c}\zeta(\mathbf{A l}) \\
{\left[\mathrm{mol} / \mathbf{m}^{2}\right]}\end{array}$ & $\begin{array}{c}\zeta(\mathbf{C a}) \\
{\left[\mathbf{m o l} / \mathbf{m}^{2}\right]}\end{array}$ & $\begin{array}{c}\mathbf{p H} \\
\text { (sim.) }\end{array}$ & $\begin{array}{l}\text { Phases } \\
\text { with SI>0 }\end{array}$ \\
\hline 0.00 & 0.00 & 0.01 & 0.04 & 0.0 & 102.37 & $8.55 \mathrm{E}-05$ & & & & & $0.00 \mathrm{E}+00$ & $0.00 \mathrm{E}+00$ & 1.50 & - \\
\hline 0.12 & 0.22 & 0.16 & 0.10 & 0.3 & 89.38 & $8.55 \mathrm{E}-05$ & $1.35 \mathrm{E}-07$ & $2.66 \mathrm{E}-07$ & 3.63E-07 & 2.43E-07 & $5.75 \mathrm{E}-03$ & $7.84 \mathrm{E}-03$ & 1.50 & - \\
\hline 0.39 & 0.59 & 0.36 & 0.21 & 0.8 & 83.95 & 4.98E-05 & 2.45E-07 & 3.44E-07 & 3.49E-07 & 3.33E-07 & $2.53 \mathrm{E}-02$ & $2.92 \mathrm{E}-02$ & 1.50 & - \\
\hline \multicolumn{15}{|c|}{ "80-2-0-P": $\mathrm{T}=80^{\circ} \mathrm{C}, \mathrm{pH}=2,[\mathrm{SiO}](\mathrm{t}=0)=0 \mathrm{M}$, powder experiment, $\Delta \mathrm{Gr}($ final $)=-92.15 \mathrm{~kJ} / \mathrm{mol}$} \\
\hline $\left.\begin{array}{c}\mathrm{Si} \\
{[\mathrm{ppm}]}\end{array}\right]$ & $\left.\begin{array}{c}\text { Al } \\
{[\mathrm{ppm}]}\end{array}\right]$ & $\left.\begin{array}{c}\text { Ca } \\
{[\text { ppm] }}\end{array}\right]$ & $\left.\begin{array}{c}\mathrm{Na} \\
{[\mathrm{ppm}]}\end{array}\right]$ & $\begin{array}{c}\text { time } \\
\text { [days] }\end{array}$ & $\begin{array}{c}\text { Fluid mass } \\
{[\mathrm{g}]}\end{array}$ & $\begin{array}{c}\text { Surface } \\
{\left[\mathbf{m}^{2}\right]}\end{array}$ & $\begin{array}{c}\text { Rate }(\mathbf{S i}) \\
{\left[\mathrm{mol} / \mathbf{m}^{2} / \mathrm{s}\right]}\end{array}$ & $\begin{array}{c}\text { Rate (Al) } \\
{\left[\mathrm{mol} / \mathrm{m}^{2} / \mathrm{s}\right]}\end{array}$ & $\begin{array}{l}\text { Rate }(\mathrm{Ca}) \\
{\left[\mathrm{mol} / \mathrm{m}^{2} / \mathrm{s}\right]}\end{array}$ & $\begin{array}{l}\text { Rate (Na) } \\
{\left[\mathrm{mol} / \mathrm{m}^{2} / \mathrm{s}\right]}\end{array}$ & $\begin{array}{c}\zeta(\mathrm{Al}) \\
{\left[\mathbf{m o l} / \mathbf{m}^{2}\right]}\end{array}$ & $\begin{array}{c}\zeta(\mathbf{C a}) \\
{\left[\mathbf{m o l} / \mathbf{m}^{2}\right]}\end{array}$ & $\begin{array}{c}\mathrm{pH} \\
\text { (sim.) }\end{array}$ & $\begin{array}{l}\text { Phases } \\
\text { with SI>0 }\end{array}$ \\
\hline 0.01 & 0.01 & 0.13 & 0.02 & 0.0 & 101.10 & $1.17 \mathrm{E}-03$ & & & & & $0.00 \mathrm{E}+00$ & $0.00 \mathrm{E}+00$ & 2.00 & - \\
\hline 1.81 & 2.01 & 1.25 & 0.51 & 1.1 & 97.07 & $1.17 \mathrm{E}-03$ & 3.72E-08 & $4.30 \mathrm{E}-08$ & 4.64E-08 & $3.56 \mathrm{E}-08$ & $4.11 \mathrm{E}-03$ & $4.44 \mathrm{E}-03$ & 2.10 & - \\
\hline 4.16 & 3.61 & 2.20 & 0.96 & 2.1 & 92.51 & $1.17 \mathrm{E}-03$ & $5.39 \mathrm{E}-08$ & $3.82 \mathrm{E}-08$ & $4.37 \mathrm{E}-08$ & 3.66E-08 & $7.25 \mathrm{E}-03$ & $8.03 \mathrm{E}-03$ & 2.10 & - \\
\hline 6.88 & 5.16 & 2.96 & 1.38 & 3.1 & 82.37 & $1.17 \mathrm{E}-03$ & $5.29 \mathrm{E}-08$ & $3.14 \mathrm{E}-08$ & $2.97 \mathrm{E}-08$ & $2.81 \mathrm{E}-08$ & $9.95 \mathrm{E}-03$ & $1.06 \mathrm{E}-02$ & 2.10 & - \\
\hline 9.39 & 6.41 & 3.79 & 1.75 & 3.9 & 73.31 & $1.17 \mathrm{E}-03$ & $5.34 \mathrm{E}-08$ & $2.76 \mathrm{E}-08$ & $3.55 \mathrm{E}-08$ & $2.81 \mathrm{E}-08$ & $1.19 \mathrm{E}-02$ & $1.31 \mathrm{E}-02$ & 2.10 & - \\
\hline 12.5 & 7.91 & 4.48 & 2.16 & 5.0 & 68.45 & $1.17 \mathrm{E}-03$ & $4.59 \mathrm{E}-08$ & 2.31E-08 & 2.05E-08 & $2.09 \mathrm{E}-08$ & $1.41 \mathrm{E}-02$ & $1.50 \mathrm{E}-02$ & 2.10 & - \\
\hline 15.7 & 9.44 & 5.46 & 2.64 & 5.9 & 63.45 & $1.17 \mathrm{E}-03$ & $5.22 \mathrm{E}-08$ & $2.59 \mathrm{E}-08$ & $3.19 \mathrm{E}-08$ & $2.74 \mathrm{E}-08$ & $1.61 \mathrm{E}-02$ & $1.75 \mathrm{E}-02$ & 2.12 & $\mathrm{Qz}$, colloid >Qz \\
\hline 31.7 & 16.6 & 9.02 & 4.75 & 11.7 & 54.60 & $1.17 \mathrm{E}-03$ & $3.56 \mathrm{E}-08$ & $1.65 \mathrm{E}-08$ & $1.59 \mathrm{E}-08$ & $1.65 \mathrm{E}-08$ & $2.44 \mathrm{E}-02$ & $2.55 \mathrm{E}-02$ & 2.18 & Qz, Trd, Chal \\
\hline \multicolumn{15}{|c|}{ "80-2.5-0-P": $\mathrm{T}=80^{\circ} \mathrm{C}, \mathrm{pH}=2.5,[\mathrm{SiO} 2](\mathrm{t}=0)=0 \mathrm{M}$, powder experiment, $\Delta \mathrm{Gr}$ (final) $=-88.02 \mathrm{~kJ} / \mathrm{mol}$} \\
\hline $\left.\begin{array}{c}\mathrm{Si} \\
{[\mathrm{ppm}]}\end{array}\right]$ & $\left.\begin{array}{c}\text { Al } \\
{[\text { ppm] }}\end{array}\right]$ & $\left.\begin{array}{c}\mathrm{Ca} \\
{[\mathrm{ppm}]}\end{array}\right]$ & $\left.\begin{array}{c}\mathrm{Na} \\
{[\mathrm{ppm}]}\end{array}\right]$ & $\begin{array}{c}\text { time } \\
\text { [days] }\end{array}$ & $\begin{array}{c}\text { Fluid mass } \\
{[\mathrm{g}]}\end{array}$ & $\begin{array}{c}\text { Surface } \\
{\left[\mathbf{m}^{2}\right]}\end{array}$ & $\begin{array}{c}\text { Rate }(\mathbf{S i}) \\
{\left[\mathrm{mol} / \mathrm{m}^{2} / \mathrm{s}\right]}\end{array}$ & $\begin{array}{c}\text { Rate (Al) } \\
{\left[\mathrm{mol} / \mathrm{m}^{2} / \mathrm{s}\right]}\end{array}$ & $\begin{array}{l}\text { Rate (Ca) } \\
{\left[\mathrm{mol} / \mathrm{m}^{2} / \mathrm{s}\right]}\end{array}$ & $\begin{array}{l}\text { Rate (Na) } \\
{\left[\mathrm{mol} / \mathrm{m}^{2} / \mathrm{s}\right]}\end{array}$ & $\begin{array}{c}\zeta(\mathrm{Al}) \\
{\left[\mathrm{mol} / \mathbf{m}^{2}\right]}\end{array}$ & $\begin{array}{c}\zeta(\mathbf{C a}) \\
{\left[\mathbf{m o l} / \mathbf{m}^{2}\right]}\end{array}$ & $\begin{array}{c}\text { pH } \\
\text { (sim.) }\end{array}$ & $\begin{array}{l}\text { Phases } \\
\text { with SI>0 }\end{array}$ \\
\hline 0.00 & 0.01 & 0.06 & 0.00 & 0.0 & 95.37 & $1.26 \mathrm{E}-03$ & & & & & $0.00 \mathrm{E}+00$ & $0.00 \mathrm{E}+00$ & 2.52 & -- \\
\hline 0.77 & 0.69 & 0.49 & 0.16 & 1.1 & 90.52 & $1.26 \mathrm{E}-03$ & $1.38 \mathrm{E}-08$ & $1.28 \mathrm{E}-08$ & $1.57 \mathrm{E}-08$ & $9.88 \mathrm{E}-09$ & $1.22 \mathrm{E}-03$ & $1.50 \mathrm{E}-03$ & 2.53 & -- \\
\hline 1.67 & 1.20 & 0.81 & 0.29 & 2.1 & 85.66 & $1.26 \mathrm{E}-03$ & $1.77 \mathrm{E}-08$ & $1.04 \mathrm{E}-08$ & $1.26 \mathrm{E}-08$ & $8.96 \mathrm{E}-09$ & $2.08 \mathrm{E}-03$ & $2.54 \mathrm{E}-03$ & 2.55 & -- \\
\hline 2.52 & 1.67 & 1.04 & 0.40 & 3.1 & 75.18 & $1.26 \mathrm{E}-03$ & $1.40 \mathrm{E}-08$ & $8.03 \mathrm{E}-09$ & 7.48E-09 & 6.41E-09 & $2.77 \mathrm{E}-03$ & $3.18 \mathrm{E}-03$ & 2.56 & -- \\
\hline 3.40 & 2.11 & 1.28 & 0.52 & 3.9 & 65.62 & $1.26 \mathrm{E}-03$ & $1.55 \mathrm{E}-08$ & $8.01 \mathrm{E}-09$ & $8.61 \mathrm{E}-09$ & 7.23E-09 & $3.33 \mathrm{E}-03$ & $3.79 \mathrm{E}-03$ & 2.57 & -- \\
\hline 4.28 & 2.56 & 1.57 & 0.63 & 5.0 & 60.65 & $1.26 \mathrm{E}-03$ & $1.06 \mathrm{E}-08$ & $5.70 \mathrm{E}-09$ & $6.91 \mathrm{E}-09$ & 4.79E-09 & $3.87 \mathrm{E}-03$ & 4.44E-03 & 2.58 & -- \\
\hline 5.19 & 3.00 & 1.76 & 0.77 & 5.9 & 56.06 & $1.26 \mathrm{E}-03$ & $1.23 \mathrm{E}-08$ & 6.18E-09 & $5.10 \mathrm{E}-09$ & 6.36E-09 & $4.36 \mathrm{E}-03$ & $4.85 \mathrm{E}-03$ & 2.59 & -- \\
\hline 9.90 & 5.44 & 3.03 & 1.40 & 11.7 & 46.27 & $1.26 \mathrm{E}-03$ & $8.22 \mathrm{E}-09$ & 4.43E-09 & 4.48E-09 & $3.88 \mathrm{E}-09$ & $6.58 \mathrm{E}-03$ & $7.08 \mathrm{E}-03$ & 2.65 & -- \\
\hline
\end{tabular}

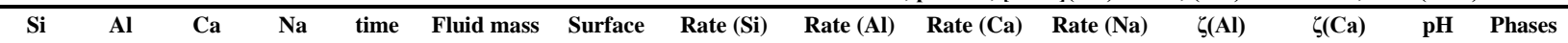




\begin{tabular}{|c|c|c|c|c|c|c|c|c|c|c|c|c|c|c|}
\hline [ppm] & [ppm] & [ppm] & [ppm] & [days] & [g] & {$\left[\mathrm{m}^{2}\right]$} & {$\left[\mathbf{m o l} / \mathbf{m}^{2} / \mathbf{s}\right]$} & {$\left[\mathrm{mol} / \mathrm{m}^{2} / \mathrm{s}\right]$} & {$\left[\mathrm{mol} / \mathrm{m}^{2} / \mathrm{s}\right]$} & {$\left[\mathrm{mol} / \mathrm{m}^{2} / \mathrm{s}\right]$} & {$\left[\mathbf{m o l} / \mathbf{m}^{2}\right]$} & {$\left[\mathbf{m o l} / \mathbf{m}^{2}\right]$} & (sim.) & with SI>0 \\
\hline 0.01 & 0.00 & 0.06 & 0.00 & 0.0 & 89.96 & $5.12 \mathrm{E}-05$ & & & & & $0.00 \mathrm{E}+00$ & $0.00 \mathrm{E}+00$ & 2.62 & - \\
\hline 0.42 & 0.35 & 0.22 & 0.06 & 1.0 & 81.74 & $5.12 \mathrm{E}-05$ & $1.78 \mathrm{E}-07$ & $1.58 \mathrm{E}-07$ & $1.40 \mathrm{E}-07$ & $9.28 \mathrm{E}-08$ & $1.40 \mathrm{E}-02$ & $1.24 \mathrm{E}-02$ & 2.63 & - \\
\hline 0.82 & 0.58 & 0.49 & 0.11 & 1.9 & 72.29 & $5.12 \mathrm{E}-05$ & $1.73 \mathrm{E}-07$ & $1.04 \mathrm{E}-07$ & $2.37 \mathrm{E}-07$ & 7.32E-08 & $2.21 \mathrm{E}-02$ & $3.08 \mathrm{E}-02$ & 2.63 & - \\
\hline 1.32 & 0.89 & 0.64 & 0.17 & 3.1 & 67.18 & $5.12 \mathrm{E}-05$ & $1.54 \mathrm{E}-07$ & $9.59 \mathrm{E}-08$ & $9.14 \mathrm{E}-08$ & $6.48 \mathrm{E}-08$ & $3.19 \mathrm{E}-02$ & $4.02 \mathrm{E}-02$ & 2.64 & - \\
\hline 1.73 & 1.09 & 0.77 & 0.23 & 4.0 & 56.94 & $5.12 \mathrm{E}-05$ & $1.46 \mathrm{E}-07$ & 7.79E-08 & $9.49 \mathrm{E}-08$ & $7.14 \mathrm{E}-08$ & $3.77 \mathrm{E}-02$ & $4.72 \mathrm{E}-02$ & 2.65 & - \\
\hline 2.20 & 1.39 & 0.92 & 0.28 & 5.0 & 52.06 & $5.12 \mathrm{E}-05$ & $1.25 \mathrm{E}-07$ & $8.14 \mathrm{E}-08$ & $7.90 \mathrm{E}-08$ & $4.70 \mathrm{E}-08$ & $4.52 \mathrm{E}-02$ & $5.45 \mathrm{E}-02$ & 2.65 & - \\
\hline \multicolumn{15}{|c|}{ "80-2.5-0-010": $\mathrm{T}=80^{\circ} \mathrm{C}, \mathrm{pH}=2.5,[\mathrm{SiO} 2](\mathrm{t}=0)=0 \mathrm{M},(010)$ orientation, $\Delta \mathrm{Gr}(\mathrm{final})=-128.72 \mathrm{~kJ} / \mathrm{mol}$} \\
\hline $\begin{array}{c}\mathrm{Si} \\
{[\mathrm{ppm}]}\end{array}$ & $\left.\begin{array}{c}\text { Al } \\
{[\mathbf{p p m}]}\end{array}\right]$ & $\left.\begin{array}{c}\mathbf{C a} \\
{[\mathrm{ppm}]}\end{array}\right]$ & $\left.\begin{array}{c}\mathrm{Na} \\
{[\mathrm{ppm}]}\end{array}\right]$ & $\begin{array}{c}\text { time } \\
\text { [days] }\end{array}$ & $\begin{array}{c}\text { Fluid mass } \\
{[\mathrm{g}]}\end{array}$ & $\begin{array}{c}\text { Surface } \\
{\left[\mathbf{m}^{2}\right]}\end{array}$ & $\begin{array}{c}\text { Rate }(\mathbf{S i}) \\
{\left[\mathrm{mol} / \mathbf{m}^{2} / \mathbf{s}\right]}\end{array}$ & $\begin{array}{c}\text { Rate (Al) } \\
{\left[\mathrm{mol} / \mathbf{m}^{2} / \mathrm{s}\right]}\end{array}$ & $\begin{array}{l}\text { Rate }(\mathrm{Ca}) \\
{\left[\mathrm{mol} / \mathbf{m}^{2} / \mathrm{s}\right]}\end{array}$ & $\begin{array}{l}\text { Rate (Na) } \\
{\left[\mathrm{mol} / \mathbf{m}^{2} / \mathrm{s}\right]}\end{array}$ & $\begin{array}{c}\zeta(\mathbf{A l}) \\
{\left[\mathbf{m o l} / \mathbf{m}^{2}\right]}\end{array}$ & $\begin{array}{c}\zeta(\mathbf{C a}) \\
{\left[\mathbf{m o l} / \mathbf{m}^{2}\right]}\end{array}$ & $\begin{array}{c}\mathrm{pH} \\
\text { (sim.) }\end{array}$ & $\begin{array}{l}\text { Phases } \\
\text { with SI>0 }\end{array}$ \\
\hline 0.00 & 0.00 & 0.10 & 0.00 & 0.0 & 94.08 & $3.22 \mathrm{E}-05$ & & & & \multirow{5}{*}{ ND } & $0.00 \mathrm{E}+00$ & $0.00 \mathrm{E}+00$ & 2.62 & - \\
\hline 0.00 & 0.01 & 0.08 & 0.00 & 0.1 & 89.99 & $3.22 \mathrm{E}-05$ & $0.00 \mathrm{E}+00$ & $6.53 \mathrm{E}-08$ & $-2.63 \mathrm{E}-07$ & & 7.64E-04 & $-3.08 \mathrm{E}-03$ & 2.62 & - \\
\hline 0.04 & 0.05 & 0.10 & 0.00 & 1.3 & 85.52 & $3.22 \mathrm{E}-05$ & 2.49E-08 & $2.34 \mathrm{E}-08$ & $2.38 \mathrm{E}-08$ & & $3.14 \mathrm{E}-03$ & $-6.63 \mathrm{E}-04$ & 2.62 & - \\
\hline 0.09 & 0.09 & 0.09 & 0.00 & 2.1 & 76.02 & $3.22 \mathrm{E}-05$ & 4.12E-08 & 3.35E-08 & $-9.93 \mathrm{E}-09$ & & $5.43 \mathrm{E}-03$ & $-1.34 \mathrm{E}-03$ & 2.62 & - \\
\hline 0.18 & 0.15 & 0.17 & 0.00 & 3.1 & 71.05 & $3.22 \mathrm{E}-05$ & $5.55 \mathrm{E}-08$ & $3.91 \mathrm{E}-08$ & $1.04 \mathrm{E}-07$ & & $8.78 \mathrm{E}-03$ & 7.55E- 03 & 2.62 & - \\
\hline 0.28 & 0.22 & 0.24 & 0.02 & 4.1 & 65.10 & $3.22 \mathrm{E}-05$ & $5.73 \mathrm{E}-08$ & 4.23E-08 & 7.36E-08 & $4.01 \mathrm{E}-08$ & $1.23 \mathrm{E}-02$ & $1.38 \mathrm{E}-02$ & 2.62 & - \\
\hline 0.43 & 0.30 & 0.26 & 0.04 & 5.1 & 60.42 & $3.22 \mathrm{E}-05$ & 7.42E- 08 & $4.22 \mathrm{E}-08$ & $1.79 \mathrm{E}-08$ & 3.98E-08 & $1.62 \mathrm{E}-02$ & $1.54 \mathrm{E}-02$ & 2.62 & - \\
\hline 0.58 & 0.38 & 0.30 & 0.07 & 6.0 & 55.55 & $3.22 \mathrm{E}-05$ & $8.08 \mathrm{E}-08$ & 4.37E- 08 & 4.22E- 08 & $4.53 \mathrm{E}-08$ & $1.95 \mathrm{E}-02$ & $1.86 \mathrm{E}-02$ & 2.63 & - \\
\hline \multicolumn{15}{|c|}{ "80-2.5-0-110": $\mathrm{T}=80^{\circ} \mathrm{C}, \mathrm{pH}=2.5,[\mathrm{SiO}](\mathrm{t}=0)=0 \mathrm{M},(110)$ orientation, $\Delta \mathrm{Gr}($ final $)=-128.52 \mathrm{~kJ} / \mathrm{mol}$} \\
\hline $\begin{array}{c}\mathrm{Si} \\
{[\mathbf{p p m}]}\end{array}$ & $\begin{array}{c}\mathbf{A l} \\
{[\mathrm{ppm}]}\end{array}$ & $\begin{array}{c}\mathrm{Ca} \\
{[\mathrm{ppm}]}\end{array}$ & $\begin{array}{c}\mathrm{Na} \\
{[\mathrm{ppm}]}\end{array}$ & $\begin{array}{l}\text { time } \\
\text { [days] }\end{array}$ & $\begin{array}{c}\text { Fluid mass } \\
{[\mathrm{g}]}\end{array}$ & $\begin{array}{c}\text { Surface } \\
{\left[\mathbf{m}^{2}\right]}\end{array}$ & $\begin{array}{c}\text { Rate }(\mathbf{S i}) \\
{\left[\mathrm{mol} / \mathbf{m}^{2} / \mathbf{s}\right]}\end{array}$ & $\begin{array}{c}\text { Rate (AI) } \\
{\left[\mathrm{mol} / \mathbf{m}^{2} / \mathrm{s}\right]}\end{array}$ & $\begin{array}{l}\text { Rate }(\mathbf{C a}) \\
{\left[\mathrm{mol} / \mathrm{m}^{2} / \mathrm{s}\right]}\end{array}$ & $\begin{array}{l}\text { Rate }(\mathrm{Na}) \\
{\left[\mathrm{mol} / \mathrm{m}^{2} / \mathrm{s}\right]}\end{array}$ & $\begin{array}{c}\zeta(\mathbf{A l}) \\
{\left[\mathbf{m o l} / \mathbf{m}^{2}\right]}\end{array}$ & $\begin{array}{c}\zeta(\mathbf{C a}) \\
{\left[\mathbf{m o l} / \mathbf{m}^{2}\right]}\end{array}$ & $\begin{array}{l}\mathrm{pH} \\
\text { (sim.) }\end{array}$ & $\begin{array}{l}\text { Phases } \\
\text { with SI>0 }\end{array}$ \\
\hline 0.00 & 0.01 & $0.25^{*}$ & 0.02 & 0.0 & 98.46 & $2.69 \mathrm{E}-05$ & & & & & $0.00 \mathrm{E}+00$ & $0.00 \mathrm{E}+00$ & 2.50 & - \\
\hline 0.07 & 0.07 & $0.26 *$ & 0.03 & 1.0 & 95.73 & $2.69 \mathrm{E}-05$ & $6.77 \mathrm{E}-08$ & $6.04 \mathrm{E}-08$ & 7.77E-09 & 4.40E-08 & $5.31 \mathrm{E}-03$ & $6.83 \mathrm{E}-04$ & 2.50 & - \\
\hline 0.17 & 0.14 & 0.36 & 0.05 & 2.0 & 90.57 & $2.69 \mathrm{E}-05$ & $9.37 \mathrm{E}-08$ & $6.83 \mathrm{E}-08$ & $1.98 \mathrm{E}-07$ & $8.53 \mathrm{E}-08$ & $1.12 \mathrm{E}-02$ & $1.76 \mathrm{E}-02$ & 2.50 & - \\
\hline 0.29 & 0.23 & 0.33 & 0.06 & 3.0 & 82.43 & $2.69 \mathrm{E}-05$ & $1.02 \mathrm{E}-07$ & $7.99 \mathrm{E}-08$ & $-5.14 \mathrm{E}-08$ & $2.99 \mathrm{E}-08$ & $1.80 \mathrm{E}-02$ & $1.32 \mathrm{E}-02$ & 2.50 & - \\
\hline 0.62 & 0.43 & 0.50 & 0.12 & 5.1 & 77.15 & $2.69 \mathrm{E}-05$ & $1.23 \mathrm{E}-07$ & 7.73E-08 & $1.28 \mathrm{E}-07$ & $6.63 \mathrm{E}-08$ & $3.23 \mathrm{E}-02$ & $3.69 \mathrm{E}-02$ & 2.51 & - \\
\hline 0.77 & 0.52 & 0.49 & 0.14 & 6.0 & 68.91 & $2.69 \mathrm{E}-05$ & $1.18 \mathrm{E}-07$ & 7.36E-08 & $-1.58 \mathrm{E}-08$ & $5.50 \mathrm{E}-08$ & $3.80 \mathrm{E}-02$ & $3.57 \mathrm{E}-02$ & 2.51 & - \\
\hline \multicolumn{15}{|c|}{ "80-2.5-0-10 $\overline{1} ": \mathrm{T}=80^{\circ} \mathrm{C}, \mathrm{pH}=2.5,[\mathrm{SiO} 2](\mathrm{t}=0)=0 \mathrm{M},(10 \overline{1})$ orientation, $\Delta \mathrm{Gr}($ final $)=-134.40 \mathrm{~kJ} / \mathrm{mol}$} \\
\hline $\begin{array}{c}\mathrm{Si} \\
{[\mathrm{ppm}]}\end{array}$ & $\left.\begin{array}{c}\mathrm{Al} \\
{[\mathrm{ppm}]}\end{array}\right]$ & $\left.\begin{array}{c}\mathrm{Ca} \\
{[\mathrm{ppm}]}\end{array}\right]$ & $\begin{array}{c}\mathrm{Na} \\
{[\mathrm{ppm}]}\end{array}$ & $\begin{array}{c}\text { time } \\
\text { [days] }\end{array}$ & $\begin{array}{c}\text { Fluid mass } \\
{[\mathrm{g}]}\end{array}$ & $\begin{array}{c}\text { Surface } \\
{\left[\mathbf{m}^{2}\right]}\end{array}$ & $\begin{array}{c}\text { Rate }(\mathbf{S i}) \\
{\left[\mathbf{m o l} / \mathbf{m}^{2} / \mathbf{s}\right]}\end{array}$ & $\begin{array}{c}\text { Rate (AI) } \\
{\left[\mathbf{m o l} / \mathbf{m}^{2} / \mathbf{s}\right]}\end{array}$ & $\begin{array}{l}\text { Rate }(\mathrm{Ca}) \\
{\left[\mathrm{mol} / \mathbf{m}^{2} / \mathrm{s}\right]}\end{array}$ & $\begin{array}{l}\text { Rate }(\mathrm{Na}) \\
{\left[\mathrm{mol} / \mathrm{m}^{2} / \mathrm{s}\right]}\end{array}$ & $\begin{array}{c}\zeta(\mathbf{A l}) \\
{\left[\mathbf{m o l} / \mathbf{m}^{2}\right]}\end{array}$ & $\begin{array}{c}\zeta(\mathbf{C a}) \\
{\left[\mathbf{m o l} / \mathbf{m}^{2}\right]}\end{array}$ & $\begin{array}{c}\mathrm{pH} \\
\text { (sim.) }\end{array}$ & $\begin{array}{l}\text { Phases } \\
\text { with SI>0 }\end{array}$ \\
\hline 0.01 & 0.01 & $0.10^{* * *}$ & 0.00 & 0.0 & 101.72 & $2.00 \mathrm{E}-05$ & & & & \multirow{3}{*}{ ND } & $0.00 \mathrm{E}+00$ & $0.00 \mathrm{E}+00$ & 2.64 & - \\
\hline 0.03 & 0.01 & 0.11 & 0.00 & 1.0 & 92.60 & $2.00 \mathrm{E}-05$ & $2.75 \mathrm{E}-08$ & $-2.35 \mathrm{E}-09$ & $4.21 \mathrm{E}-09$ & & $-2.08 \mathrm{E}-04$ & 3.73E-04 & 2.64 & - \\
\hline 0.07 & 0.04 & 0.12 & 0.00 & 1.9 & 83.18 & $2.00 \mathrm{E}-05$ & 4.67E- 08 & $3.64 \mathrm{E}-08$ & 4.07E-08 & & $2.62 \mathrm{E}-03$ & $3.53 \mathrm{E}-03$ & 2.64 & - \\
\hline 0.13 & 0.08 & 0.14 & 0.00 & 3.1 & 77.97 & $2.00 \mathrm{E}-05$ & $6.20 \mathrm{E}-08$ & $3.78 \mathrm{E}-08$ & $3.42 \mathrm{E}-08$ & $1.01 \mathrm{E}-08$ & $6.51 \mathrm{E}-03$ & 7.06E-03 & 2.65 & - \\
\hline 0.22 & 0.14 & 0.20 & 0.06 & 4.0 & 68.28 & $2.00 \mathrm{E}-05$ & $9.24 \mathrm{E}-08$ & 7.66E- 08 & $1.39 \mathrm{E}-07$ & $2.01 \mathrm{E}-07$ & $1.22 \mathrm{E}-02$ & $1.74 \mathrm{E}-02$ & 2.65 & - \\
\hline 0.36 & 0.24 & 0.24 & 0.04 & 5.0 & 63.58 & $2.00 \mathrm{E}-05$ & $1.18 \mathrm{E}-07$ & $8.36 \mathrm{E}-08$ & $5.91 \mathrm{E}-08$ & $-3.87 \mathrm{E}-08$ & $1.99 \mathrm{E}-02$ & $2.28 \mathrm{E}-02$ & 2.65 & - \\
\hline \multicolumn{15}{|c|}{ "80-3-0-1": $\mathrm{T}=80^{\circ} \mathrm{C}, \mathrm{pH}=3,[\mathrm{SiO}](\mathrm{t}=0)=0 \mathrm{M}$, multiple orientations experiment, $\Delta \mathrm{Gr}($ final $)=-73.49 \mathrm{~kJ} / \mathrm{mol}$} \\
\hline $\begin{array}{c}\mathrm{Si} \\
{[\mathrm{ppm}]}\end{array}$ & $\begin{array}{c}\mathbf{A l} \\
{[\mathrm{ppm}]}\end{array}$ & $\begin{array}{c}\mathrm{Ca} \\
{[\mathrm{ppm}]}\end{array}$ & $\begin{array}{c}\mathrm{Na} \\
{[\mathrm{ppm}]}\end{array}$ & $\begin{array}{l}\text { time } \\
\text { [days] }\end{array}$ & $\begin{array}{l}\text { Fluid mass } \\
{[\mathrm{g}]}\end{array}$ & $\begin{array}{c}\text { Surface } \\
{\left[\mathbf{m}^{2}\right]}\end{array}$ & $\begin{array}{c}\text { Rate }(\mathbf{S i}) \\
{\left[\mathrm{mol} / \mathbf{m}^{2} / \mathrm{s}\right]}\end{array}$ & $\begin{array}{c}\text { Rate (AI) } \\
{\left[\mathrm{mol} / \mathbf{m}^{2} / \mathrm{s}\right]}\end{array}$ & $\begin{array}{l}\text { Rate }(\mathrm{Ca}) \\
{\left[\mathrm{mol} / \mathrm{m}^{2} / \mathrm{s}\right]}\end{array}$ & $\begin{array}{l}\text { Rate (Na) } \\
{\left[\mathrm{mol} / \mathrm{m}^{2} / \mathrm{s}\right]}\end{array}$ & $\begin{array}{c}\zeta(\mathbf{A l}) \\
{\left[\mathbf{m o l} / \mathbf{m}^{2}\right]}\end{array}$ & $\begin{array}{c}\zeta(\mathbf{C a}) \\
{\left[\mathbf{m o l} / \mathbf{m}^{2}\right]}\end{array}$ & $\begin{array}{l}\mathbf{p H} \\
\text { (sim.) }\end{array}$ & $\begin{array}{l}\text { Phases } \\
\text { with SI>0 }\end{array}$ \\
\hline 0.19 & 0.00 & 0.05 & 0.34 & 0.0 & 114.69 & $3.00 \mathrm{E}-04$ & & & & & $0.00 \mathrm{E}+00$ & $1.83 \mathrm{E}-05$ & 3.01 & - \\
\hline 1.44 & 0.78 & 0.55 & 0.24 & 4.0 & 110.98 & 3.00E-04 & $3.21 \mathrm{E}-08$ & $2.08 \mathrm{E}-08$ & $2.56 \mathrm{E}-08$ & $-8.45 \mathrm{E}-09$ & $7.20 \mathrm{E}-03$ & $8.87 \mathrm{E}-03$ & 3.06 & Dsp \\
\hline 2.76 & 1.53 & 0.97 & 0.35 & 10.0 & 107.27 & $3.00 \mathrm{E}-04$ & $2.18 \mathrm{E}-08$ & $1.28 \mathrm{E}-08$ & $1.38 \mathrm{E}-08$ & $6.22 \mathrm{E}-09$ & $1.38 \mathrm{E}-02$ & $1.60 \mathrm{E}-02$ & 3.11 & Dsp, Bhm \\
\hline 3.45 & 1.88 & 1.19 & 0.46 & 14.0 & 103.56 & $3.00 \mathrm{E}-04$ & $1.64 \mathrm{E}-08$ & $8.80 \mathrm{E}-09$ & $1.03 \mathrm{E}-08$ & $9.01 \mathrm{E}-09$ & $1.69 \mathrm{E}-02$ & $1.96 \mathrm{E}-02$ & 3.14 & Dsp, Bhm, Gbs \\
\hline 4.02 & 2.20 & 1.33 & 0.54 & 18.0 & 99.85 & $3.00 \mathrm{E}-04$ & $1.30 \mathrm{E}-08$ & 7.62E-09 & $6.85 \mathrm{E}-09$ & $6.51 \mathrm{E}-09$ & $1.95 \mathrm{E}-02$ & $2.20 \mathrm{E}-02$ & 3.17 & Dsp, Bhm, Gbs, Kln \\
\hline 4.61 & 2.51 & 1.52 & 0.62 & 21.0 & 96.18 & $3.00 \mathrm{E}-04$ & $1.75 \mathrm{E}-08$ & $9.58 \mathrm{E}-09$ & $1.12 \mathrm{E}-08$ & $8.37 \mathrm{E}-09$ & $2.20 \mathrm{E}-02$ & $2.49 \mathrm{E}-02$ & 3.20 & Dsp, Bhm, Gbs, Kln \\
\hline 5.31 & 2.90 & 1.74 & 0.71 & 27.0 & 92.64 & $3.00 \mathrm{E}-04$ & $9.98 \mathrm{E}-09$ & $5.79 \mathrm{E}-09$ & $6.16 \mathrm{E}-09$ & $4.70 \mathrm{E}-09$ & $2.50 \mathrm{E}-02$ & $2.81 \mathrm{E}-02$ & 3.23 & Dsp, Bhm, Gbs, Kln \\
\hline \multicolumn{15}{|c|}{ "80-3-0-2": $\mathrm{T}=80^{\circ} \mathrm{C}, \mathrm{pH}=3,[\mathrm{SiO} 2](\mathrm{t}=0)=0 \mathrm{M}$, multiple orientations experiment, $\Delta \mathrm{Gr}(\mathrm{final})=-60.32 \mathrm{~kJ} / \mathrm{mol}$} \\
\hline $\begin{array}{c}\mathrm{Si} \\
{[\mathrm{ppm}]}\end{array}$ & $\left.\begin{array}{c}\text { Al } \\
{[\text { ppm] }}\end{array}\right]$ & $\begin{array}{c}\text { Ca } \\
{[\text { ppm] }}\end{array}$ & $\left.\begin{array}{c}\mathrm{Na} \\
{[\mathrm{ppm}]}\end{array}\right]$ & $\begin{array}{l}\text { time } \\
\text { [days] }\end{array}$ & $\begin{array}{l}\text { Fluid mass } \\
{[\mathrm{g}]}\end{array}$ & $\begin{array}{c}\text { Surface } \\
{\left[\mathbf{m}^{2}\right]}\end{array}$ & $\begin{array}{c}\text { Rate }(\mathbf{S i}) \\
{\left[\mathrm{mol} / \mathbf{m}^{2} / \mathrm{s}\right]}\end{array}$ & $\begin{array}{c}\text { Rate (Al) } \\
{\left[\mathrm{mol} / \mathbf{m}^{2} / \mathrm{s}\right]}\end{array}$ & $\begin{array}{l}\text { Rate }(\mathrm{Ca}) \\
{\left[\mathrm{mol} / \mathbf{m}^{2} / \mathrm{s}\right]}\end{array}$ & $\begin{array}{l}\text { Rate (Na) } \\
{\left[\mathrm{mol} / \mathrm{m}^{2} / \mathrm{s}\right]}\end{array}$ & $\begin{array}{c}\zeta(\mathbf{A l}) \\
{\left[\mathbf{m o l} / \mathbf{m}^{2}\right]}\end{array}$ & $\begin{array}{c}\zeta(\mathbf{C a}) \\
{\left[\mathbf{m o l} / \mathbf{m}^{2}\right]}\end{array}$ & $\begin{array}{l}\mathbf{p H} \\
\text { (sim.) }\end{array}$ & $\begin{array}{l}\text { Phases } \\
\text { with SI>0 }\end{array}$ \\
\hline 0.03 & 0.00 & 0.04 & 0.01 & 0.0 & 111.36 & $6.50 \mathrm{E}-04$ & & & & & $0.00 \mathrm{E}+00$ & $0.00 \mathrm{E}+00$ & 3.01 & - \\
\hline 1.71 & 1.02 & 0.71 & 0.24 & 4.0 & 104.23 & $6.50 \mathrm{E}-04$ & $1.87 \mathrm{E}-08$ & $1.17 \mathrm{E}-08$ & $1.50 \mathrm{E}-08$ & $8.89 \mathrm{E}-09$ & 4.05E-03 & $5.18 \mathrm{E}-03$ & 3.08 & Dsp, Bhm \\
\hline
\end{tabular}




\begin{tabular}{|c|c|c|c|c|c|c|c|c|c|c|c|c|c|c|}
\hline 2.41 & 1.41 & 0.93 & 0.32 & 7.0 & 100.35 & $6.50 \mathrm{E}-04$ & $9.97 \mathrm{E}-09$ & $5.79 \mathrm{E}-09$ & $6.16 \mathrm{E}-09$ & 4.03E-09 & $5.55 \mathrm{E}-03$ & $6.78 \mathrm{E}-03$ & 3.12 & Dsp, Bhm \\
\hline 3.40 & 1.95 & 1.23 & 0.46 & 12.0 & 95.83 & $6.50 \mathrm{E}-04$ & $8.02 \mathrm{E}-09$ & $4.58 \mathrm{E}-09$ & 4.85E-09 & 3.85E-09 & $7.52 \mathrm{E}-03$ & $8.88 \mathrm{E}-03$ & 3.15 & Dsp, Bhm, Gbs \\
\hline 4.22 & 2.39 & 1.48 & 0.58 & 18.0 & 91.83 & $6.50 \mathrm{E}-04$ & 5.35E-09 & $2.98 \mathrm{E}-09$ & 3.35E-09 & 2.77E-09 & $9.07 \mathrm{E}-03$ & $1.06 \mathrm{E}-02$ & 3.19 & Kln, Dsp, Bhm, Gbs \\
\hline 5.06 & 2.84 & 1.74 & 0.69 & 25.0 & 88.16 & $6.50 \mathrm{E}-04$ & 4.48E-09 & $2.54 \mathrm{E}-09$ & 2.76E-09 & 2.02E-09 & $1.06 \mathrm{E}-02$ & $1.23 \mathrm{E}-02$ & 3.23 & Kln, Dsp, Bhm, Gbs \\
\hline 5.66 & 3.16 & 1.93 & 0.76 & 31.0 & 84.60 & $6.50 \mathrm{E}-04$ & 3.64E-09 & 2.01E-09 & $2.27 \mathrm{E}-09$ & $1.42 \mathrm{E}-09$ & $1.16 \mathrm{E}-02$ & $1.35 \mathrm{E}-02$ & 3.26 & Kln, Dsp, Bhm, Crn, Gbs \\
\hline 6.24 & 3.48 & 2.10 & 0.85 & 37.0 & 80.86 & $6.50 \mathrm{E}-04$ & 3.32E-09 & $1.90 \mathrm{E}-09$ & 2.02E-09 & $1.89 \mathrm{E}-09$ & $1.26 \mathrm{E}-02$ & $1.45 \mathrm{E}-02$ & 3.29 & Kln, Dsp, Bhm, Bei-H, Crn, Gbs \\
\hline 7.04 & 3.86 & 2.35 & 0.96 & 46.0 & 76.81 & $6.50 \mathrm{E}-04$ & $2.89 \mathrm{E}-09$ & $1.43 \mathrm{E}-09$ & $1.77 \mathrm{E}-09$ & $1.37 \mathrm{E}-09$ & $1.37 \mathrm{E}-02$ & $1.59 \mathrm{E}-02$ & 3.34 & Kln, Dsp, Bhm, Bei-H, Crn, Gbs, Bei-Ca, Prl \\
\hline 7.43 & 4.07 & 2.47 & 1.00 & 53.0 & 72.73 & $6.50 \mathrm{E}-04$ & $1.73 \mathrm{E}-09$ & $9.49 \mathrm{E}-10$ & $1.08 \mathrm{E}-09$ & $6.26 \mathrm{E}-10$ & $1.43 \mathrm{E}-02$ & $1.65 \mathrm{E}-02$ & 3.36 & Kln, Dsp, Bhm, Bei-H, Crn, Gbs, Bei-Ca, Prl \\
\hline 7.91 & 4.29 & 2.60 & 1.04 & 60.0 & 69.23 & $6.50 \mathrm{E}-04$ & 2.01E-09 & $9.87 \mathrm{E}-10$ & $1.12 \mathrm{E}-09$ & $6.22 \mathrm{E}-10$ & $1.49 \mathrm{E}-02$ & $1.72 \mathrm{E}-02$ & 3.39 & Kln, Dsp, Bhm, Bei-H, Crn, Gbs, Bei-Ca, Prl \\
\hline 8.28 & 4.52 & 2.75 & 1.09 & 64.0 & 65.33 & $6.50 \mathrm{E}-04$ & $2.59 \mathrm{E}-09$ & $1.68 \mathrm{E}-09$ & $2.05 \mathrm{E}-09$ & $1.30 \mathrm{E}-09$ & $1.55 \mathrm{E}-02$ & $1.79 \mathrm{E}-02$ & 3.42 & Kln, Dsp, Bhm, Bei-H, Crn, Gbs, Bei-Ca, Prl, Bei-Na \\
\hline \multicolumn{15}{|c|}{ "80-1.5-SiO2-1": $\mathrm{T}=80^{\circ} \mathrm{C}, \mathrm{pH}=1.5,[\mathrm{SiO}](\mathrm{t}=0)=5.2 \mathrm{E}-3 \mathrm{M}$, multiple orientations experiment, $\Delta \mathrm{Gr}(\mathrm{final})=-96.74 \mathrm{~kJ} / \mathrm{mol}$} \\
\hline $\left.\begin{array}{c}\mathrm{Si} \\
{[\mathrm{ppm}]}\end{array}\right]$ & $\left.\begin{array}{c}\text { Al } \\
{[\mathrm{ppm}]}\end{array}\right]$ & $\left.\begin{array}{c}\mathbf{C a} \\
{[\mathrm{ppm}]}\end{array}\right]$ & $\left.\begin{array}{c}\mathrm{Na} \\
{[\mathrm{ppm}]}\end{array}\right]$ & $\begin{array}{c}\text { time } \\
\text { [days] }\end{array}$ & $\begin{array}{c}\text { Fluid mass } \\
{[\mathrm{g}]}\end{array}$ & $\begin{array}{c}\text { Surface } \\
{\left[\mathbf{m}^{2}\right]}\end{array}$ & $\begin{array}{c}\text { Rate }(\mathbf{S i}) \\
{\left[\mathrm{mol} / \mathrm{m}^{2} / \mathrm{s}\right]}\end{array}$ & $\begin{array}{c}\text { Rate (Al) } \\
{\left[\mathrm{mol} / \mathbf{m}^{2} / \mathbf{s}\right]} \\
\end{array}$ & $\begin{array}{l}\text { Rate }(\mathbf{C a}) \\
{\left[\mathrm{mol} / \mathrm{m}^{2} / \mathrm{s}\right]} \\
\end{array}$ & $\begin{array}{l}\text { Rate (Na) } \\
{\left[\mathrm{mol} / \mathrm{m}^{2} / \mathrm{s}\right]}\end{array}$ & $\begin{array}{c}\zeta(\mathrm{Al}) \\
{\left[\mathrm{mol} / \mathbf{m}^{2}\right]}\end{array}$ & $\begin{array}{c}\zeta(\mathbf{C a}) \\
{\left[\mathbf{m o l} / \mathbf{m}^{2}\right]}\end{array}$ & $\begin{array}{l}\mathrm{pH} \\
\text { (sim.) }\end{array}$ & $\begin{array}{l}\text { Phases } \\
\text { with SI>0 }\end{array}$ \\
\hline $146^{*}$ & 0.02 & 0.03 & $239^{*}$ & 0.0 & 119.32 & $3.00 \mathrm{E}-04$ & \multirow{7}{*}{ ND } & & & \multirow{7}{*}{ ND } & $0.00 \mathrm{E}+00$ & $0.00 \mathrm{E}+00$ & 1.50 & Qz, Trd, Chal, Crs(alpha), Coe, Crs(beta), SiO2 (am) \\
\hline 153 & 4.12 & 2.20 & 240 & 4.0 & 115.61 & $3.00 \mathrm{E}-04$ & & $1.14 \mathrm{E}-07$ & $1.16 \mathrm{E}-07$ & & 3.93E-02 & 4.01E-02 & 1.51 & Qz, Trd, Chal, Crs(alpha), Coe, $\mathrm{Crs}($ beta), $\mathrm{SiO} 2$ (am) \\
\hline 166 & 10.8 & 5.81 & 242 & 10.0 & 111.90 & $3.00 \mathrm{E}-04$ & & $1.20 \mathrm{E}-07$ & $1.25 \mathrm{E}-07$ & & $1.02 \mathrm{E}-01$ & $1.05 \mathrm{E}-01$ & 1.52 & Qz, Trd, Chal, Crs(alpha), Coe, $\mathrm{Crs}($ beta), $\mathrm{SiO} 2$ (am) \\
\hline 176 & 16.4 & 8.94 & 244 & 14.0 & 108.19 & $3.00 \mathrm{E}-04$ & & $1.45 \mathrm{E}-07$ & $1.57 \mathrm{E}-07$ & & $1.52 \mathrm{E}-01$ & $1.59 \mathrm{E}-01$ & 1.53 & Qz, Trd, Chal, Crs(alpha), Coe, Crs(beta), $\mathrm{SiO}$ (am) \\
\hline 186 & 21.4 & 11.9 & 245 & 18.0 & 104.48 & $3.00 \mathrm{E}-04$ & & $1.25 \mathrm{E}-07$ & $1.45 \mathrm{E}-07$ & & $1.95 \mathrm{E}-01$ & $2.09 \mathrm{E}-01$ & 1.54 & Qz, Trd, Chal, Crs(alpha), Coe, Crs(beta), $\mathrm{SiO}$ (am) \\
\hline 197 & 26.6 & 15.2 & 247 & 21.0 & 100.97 & $3.00 \mathrm{E}-04$ & & $1.65 \mathrm{E}-07$ & 2.05E-07 & & $2.38 \mathrm{E}-01$ & $2.62 \mathrm{E}-01$ & 1.55 & Qz, Trd, Chal, Crs(alpha), Coe, Crs(beta), $\mathrm{SiO}$ (am) \\
\hline 214 & 33.7 & 20.2 & 249 & 27.0 & 97.68 & $3.00 \mathrm{E}-04$ & & $1.12 \mathrm{E}-07$ & $1.49 \mathrm{E}-07$ & & $2.96 \mathrm{E}-01$ & $3.39 \mathrm{E}-01$ & 1.57 & Qz, Trd, Chal, Crs(alpha), Coe, Crs(beta), $\mathrm{SiO}$ (am) \\
\hline \multicolumn{15}{|c|}{ "80-2.5-SiO2-001": $\mathrm{T}=80^{\circ} \mathrm{C}, \mathrm{pH}=2.5,[\mathrm{SiO} 2](\mathrm{t}=0)=5.2 \mathrm{E}-3 \mathrm{M},(001)$ orientation, $\Delta \mathrm{Gr}($ final $)=* * \mathrm{~kJ} / \mathrm{mol}$} \\
\hline $\begin{array}{c}\mathbf{S i} \\
{[\mathrm{ppm}]}\end{array}$ & $\begin{array}{c}\text { Al } \\
{[\mathbf{p p m}]}\end{array}$ & $\begin{array}{c}\text { Ca } \\
{[\text { ppm] }}\end{array}$ & $\begin{array}{c}\mathrm{Na} \\
{[\mathrm{ppm}]}\end{array}$ & $\begin{array}{l}\text { time } \\
\text { [days] }\end{array}$ & $\begin{array}{c}\text { Fluid mass } \\
{[\mathrm{g}]}\end{array}$ & $\begin{array}{c}\text { Surface } \\
{\left[\mathbf{m}^{2}\right]}\end{array}$ & $\begin{array}{c}\text { Rate }(\mathbf{S i}) \\
{\left[\mathrm{mol} / \mathrm{m}^{2} / \mathrm{s}\right]}\end{array}$ & $\begin{array}{c}\text { Rate (Al) } \\
{\left[\mathrm{mol} / \mathrm{m}^{2} / \mathrm{s}\right]}\end{array}$ & $\begin{array}{l}\text { Rate }(\mathrm{Ca}) \\
{\left[\mathrm{mol} / \mathrm{m}^{2} / \mathrm{s}\right]}\end{array}$ & $\begin{array}{l}\text { Rate }(\mathbf{N a}) \\
{\left[\mathrm{mol} / \mathbf{m}^{2} / \mathrm{s}\right]}\end{array}$ & $\begin{array}{c}\zeta(\mathrm{Al}) \\
{\left[\mathbf{m o l} / \mathbf{m}^{2}\right]}\end{array}$ & $\begin{array}{c}\zeta(\mathbf{C a}) \\
{\left[\mathbf{m o l} / \mathbf{m}^{2}\right]}\end{array}$ & $\begin{array}{l}\mathbf{p H} \\
\text { (sim.) }\end{array}$ & $\begin{array}{l}\text { Phases } \\
\text { with SI>0 }\end{array}$ \\
\hline \multirow{8}{*}{ ND } & 0.00 & \multirow{8}{*}{ ND } & \multirow{8}{*}{ ND } & 0.0 & 105.91 & $2.51 \mathrm{E}-05$ & \multirow{8}{*}{ ND } & & \multirow{8}{*}{ ND } & \multirow{8}{*}{ ND } & $0.00 \mathrm{E}+00$ & \multirow{8}{*}{ ND } & \multirow{8}{*}{ ND } & \multirow{8}{*}{ ND } \\
\hline & 0.02 & & & 2.0 & 100.50 & $2.51 \mathrm{E}-05$ & & $1.36 \mathrm{E}-08$ & & & $2.34 \mathrm{E}-03$ & & & \\
\hline & 0.03 & & & 3.9 & 95.69 & $2.51 \mathrm{E}-05$ & & $4.68 \mathrm{E}-09$ & & & $3.10 \mathrm{E}-03$ & & & \\
\hline & 0.04 & & & 6.6 & 92.00 & $2.51 \mathrm{E}-05$ & & 4.10E-09 & & & 4.05E-03 & & & \\
\hline & 0.05 & & & 8.6 & 88.40 & $2.51 \mathrm{E}-05$ & & $3.20 \mathrm{E}-09$ & & & 4.62E- 03 & & & \\
\hline & 0.05 & & & 10.8 & 84.77 & $2.51 \mathrm{E}-05$ & & $1.40 \mathrm{E}-09$ & & & $4.88 \mathrm{E}-03$ & & & \\
\hline & 0.07 & & & 15.6 & 76.93 & $2.51 \mathrm{E}-05$ & & $2.84 \mathrm{E}-09$ & & & $6.06 \mathrm{E}-03$ & & & \\
\hline & 0.08 & & & 20.7 & 73.22 & $2.51 \mathrm{E}-05$ & & 2.67E-09 & & & $7.24 \mathrm{E}-03$ & & & \\
\hline \multicolumn{15}{|c|}{ "80-2.5-SiO2-010": $\mathrm{T}=80^{\circ} \mathrm{C}, \mathrm{pH}=2.5,[\mathrm{SiO} 2](\mathrm{t}=0)=5.2 \mathrm{E}-3 \mathrm{M},(010)$ orientation, $\Delta \mathrm{Gr}(\mathrm{final})=-92.28 \mathrm{~kJ} / \mathrm{mol}$} \\
\hline $\left.\begin{array}{c}\mathrm{Si} \\
{[\mathrm{ppm}]}\end{array}\right]$ & $\left.\begin{array}{c}\text { Al } \\
{[\mathrm{ppm}]}\end{array}\right]$ & $\left.\begin{array}{c}\mathbf{C a} \\
{[\mathrm{ppm}]}\end{array}\right]$ & $\left.\begin{array}{c}\mathrm{Na} \\
{[\mathrm{ppm}]}\end{array}\right]$ & $\begin{array}{c}\text { time } \\
\text { [days] }\end{array}$ & $\begin{array}{c}\begin{array}{c}\text { Fluid mass } \\
{[\mathrm{g}]}\end{array} \\
\end{array}$ & $\begin{array}{c}\text { Surface } \\
{\left[\mathbf{m}^{2}\right]}\end{array}$ & $\begin{array}{c}\text { Rate }(\mathbf{S i}) \\
{\left[\mathrm{mol} / \mathbf{m}^{2} / \mathrm{s}\right]}\end{array}$ & $\begin{array}{c}\text { Rate (AI) } \\
{\left[\mathrm{mol} / \mathbf{m}^{2} / \mathbf{s}\right]}\end{array}$ & $\begin{array}{l}\text { Rate }(\mathbf{C a}) \\
{\left[\mathrm{mol} / \mathbf{m}^{2} / \mathrm{s}\right]}\end{array}$ & $\begin{array}{l}\text { Rate }(\mathrm{Na}) \\
{\left[\mathrm{mol} / \mathrm{m}^{2} / \mathrm{s}\right]}\end{array}$ & $\begin{array}{c}\zeta(\mathbf{A l}) \\
{\left[\mathbf{m o l} / \mathbf{m}^{2}\right]}\end{array}$ & $\begin{array}{c}\zeta(\mathbf{C a}) \\
{\left[\mathbf{m o l} / \mathbf{m}^{2}\right]}\end{array}$ & $\begin{array}{l}\mathbf{p H} \\
\text { (sim.) }\end{array}$ & $\begin{array}{l}\text { Phases } \\
\text { with SI>0 }\end{array}$ \\
\hline $146^{*}$ & 0.02 & $0.10^{*}$ & $239^{*}$ & 0.0 & 96.28 & $1.82 \mathrm{E}-05$ & \multirow{12}{*}{ ND } & $1.54 \mathrm{E}-08$ & $2.24 \mathrm{E}-08$ & \multirow{12}{*}{ ND } & $0.00 \mathrm{E}+00$ & $0.00 \mathrm{E}+00$ & 2.57 & Qz, Trd, Chal, Crs(alpha), Coe, Crs(beta), $\mathrm{SiO} 2$ (am) \\
\hline 146 & 0.02 & 0.15 & 239 & 1.0 & 96.24 & $1.82 \mathrm{E}-05$ & & $2.10 \mathrm{E}-09$ & $1.37 \mathrm{E}-07$ & & $1.89 \mathrm{E}-04$ & $1.23 \mathrm{E}-02$ & 2.57 & Qz, Trd, Chal, Crs(alpha), Coe, Crs(beta), $\mathrm{SiO} 2$ (am) \\
\hline 146 & 0.02 & 0.11 & 239 & 2.0 & 91.70 & $1.82 \mathrm{E}-05$ & & $-6.03 \mathrm{E}-12$ & $-1.16 \mathrm{E}-07$ & & $1.89 \mathrm{E}-04$ & $2.87 \mathrm{E}-03$ & 2.57 & Qz, Trd, Chal, Crs(alpha), Coe, $\operatorname{Crs}($ beta), $\mathrm{SiO} 2$ (am) \\
\hline 146 & 0.02 & 0.16 & 239 & 4.0 & 82.80 & $1.82 \mathrm{E}-05$ & & $1.09 \mathrm{E}-09$ & $6.44 \mathrm{E}-08$ & & 3.73E-04 & $1.38 \mathrm{E}-02$ & 2.57 & Qz, Trd, Chal, Crs(alpha), Coe, Crs(beta), $\mathrm{SiO} 2$ (am) \\
\hline 146 & 0.02 & 0.16 & 239 & 4.9 & 78.14 & $1.82 \mathrm{E}-05$ & & $1.14 \mathrm{E}-09$ & $1.40 \mathrm{E}-08$ & & 4.71E-04 & $1.50 \mathrm{E}-02$ & 2.57 & Qz, Trd, Chal, Crs(alpha), Coe, $\mathrm{Crs}($ beta), $\mathrm{SiO} 2$ (am) \\
\hline 146 & 0.03 & 0.15 & 239 & 5.9 & 73.62 & $1.82 \mathrm{E}-05$ & & 2.49E-09 & $-3.40 \mathrm{E}-08$ & & $6.78 \mathrm{E}-04$ & $1.22 \mathrm{E}-02$ & 2.57 & Qz, Trd, Chal, Crs(alpha), Coe, Crs(beta), $\mathrm{SiO}$ (am) \\
\hline 146 & 0.03 & 0.15 & 239 & 7.0 & 64.17 & $1.82 \mathrm{E}-05$ & & $8.23 \mathrm{E}-10$ & 8.43E-09 & & 7.54E-04 & $1.30 \mathrm{E}-02$ & 2.57 & Qz, Trd, Chal, Crs(alpha), Coe, $\mathrm{Crs}($ beta), $\mathrm{SiO} 2$ (am) \\
\hline 146 & 0.03 & 0.21 & 239 & 7.9 & 59.53 & $1.82 \mathrm{E}-05$ & & $1.04 \mathrm{E}-09$ & $1.09 \mathrm{E}-07$ & & $8.35 \mathrm{E}-04$ & $2.15 \mathrm{E}-02$ & 2.57 & Qz, Trd, Chal, Crs(alpha), Coe, Crs(beta), $\mathrm{SiO}$ (am) \\
\hline 146 & 0.03 & 0.16 & 239 & 11.1 & 54.72 & $1.82 \mathrm{E}-05$ & & $9.05 \mathrm{E}-10$ & $-2.52 \mathrm{E}-08$ & & $1.08 \mathrm{E}-03$ & $1.46 \mathrm{E}-02$ & 2.57 & Qz, Trd, Chal, Crs(alpha), Coe, Crs(beta), $\mathrm{SiO}$ (am) \\
\hline 146 & 0.03 & 0.15 & 239 & 13.0 & 50.08 & $1.82 \mathrm{E}-05$ & & $1.32 \mathrm{E}-09$ & $-1.14 \mathrm{E}-08$ & & $1.30 \mathrm{E}-03$ & $1.27 \mathrm{E}-02$ & 2.57 & Qz, Trd, Chal, Crs(alpha), Coe, Crs(beta), $\mathrm{SiO} 2$ (am) \\
\hline 146 & 0.04 & 0.20 & 239 & 16.0 & 41.04 & $1.82 \mathrm{E}-05$ & & $7.67 \mathrm{E}-10$ & $2.43 \mathrm{E}-08$ & & $1.50 \mathrm{E}-03$ & $1.90 \mathrm{E}-02$ & 2.57 & Qz, Trd, Chal, Crs(alpha), Coe, Crs(beta), $\mathrm{SiO}$ (am) \\
\hline 146 & 0.04 & 0.15 & 239 & 18.0 & 37.82 & $1.82 \mathrm{E}-05$ & & $1.22 \mathrm{E}-09$ & $-3.21 \mathrm{E}-08$ & & $1.72 \mathrm{E}-03$ & $1.33 \mathrm{E}-02$ & 2.57 & Qz, Trd, Chal, Crs(alpha), Coe, Crs(beta), $\mathrm{SiO} 2$ (am) \\
\hline \multicolumn{15}{|c|}{$\mathrm{n}, \Delta \mathrm{Gr}(\mathrm{final})=-85.25 \mathrm{~kJ} / \mathrm{mol}$} \\
\hline $\begin{array}{c}\mathbf{S i} \\
{[\mathrm{ppm}]}\end{array}$ & $\begin{array}{c}\mathrm{Al} \\
{[\mathrm{ppm}]}\end{array}$ & $\begin{array}{c}\text { Ca } \\
{[\mathrm{ppm}]}\end{array}$ & $\begin{array}{c}\mathrm{Na} \\
{[\mathrm{ppm}]}\end{array}$ & $\begin{array}{l}\text { time } \\
\text { [days] }\end{array}$ & $\begin{array}{l}\text { Fluid mass } \\
{[\mathrm{g}]}\end{array}$ & $\begin{array}{c}\text { Surface } \\
{\left[\mathbf{m}^{2}\right]}\end{array}$ & $\begin{array}{c}\text { Rate (Si) } \\
{\left[\mathrm{mol} / \mathbf{m}^{2} / \mathbf{s}\right]}\end{array}$ & $\begin{array}{c}\text { Rate (Al) } \\
{\left[\mathrm{mol} / \mathrm{m}^{2} / \mathrm{s}\right]}\end{array}$ & $\begin{array}{l}\text { Rate (Ca) } \\
{\left[\mathrm{mol} / \mathrm{m}^{2} / \mathrm{s}\right]}\end{array}$ & $\begin{array}{l}\text { Rate (Na) } \\
{\left[\mathrm{mol} / \mathrm{m}^{2} / \mathrm{s}\right]}\end{array}$ & $\begin{array}{c}\zeta(\mathrm{Al}) \\
{\left[\mathbf{m o l} / \mathbf{m}^{2}\right]}\end{array}$ & $\begin{array}{c}\zeta(\mathbf{C a}) \\
{\left[\mathbf{m o l} / \mathbf{m}^{2}\right]}\end{array}$ & $\begin{array}{c}\text { pH } \\
\text { (sim.) }\end{array}$ & $\begin{array}{l}\text { Phases } \\
\text { with SI>0 }\end{array}$ \\
\hline
\end{tabular}




\begin{tabular}{ccccccc}
$146 *$ & 0.02 & $0.27 *$ & $239 *$ & 0.0 & 108.09 & $5.55 \mathrm{E}-05$ \\
146 & 0.03 & 0.23 & 239 & 1.0 & 99.86 & $5.55 \mathrm{E}-05$ \\
146 & 0.03 & 0.27 & 239 & 2.0 & 94.64 & $5.55 \mathrm{E}-05$ \\
146 & 0.04 & 0.38 & 239 & 4.0 & 83.93 & $5.55 \mathrm{E}-05$ \\
146 & 0.04 & 0.37 & 239 & 4.9 & 79.11 & $5.55 \mathrm{E}-05$ \\
146 & 0.05 & 0.38 & 239 & 5.9 & 74.56 & $5.55 \mathrm{E}-05$ \\
146 & 0.05 & 0.42 & 239 & 7.0 & 65.26 & $5.55 \mathrm{E}-05$ \\
146 & 0.05 & 0.47 & 239 & 7.9 & 60.55 & $5.55 \mathrm{E}-05$ \\
146 & 0.07 & 0.48 & 239 & 11.1 & 55.38 & $5.55 \mathrm{E}-05$ \\
146 & 0.08 & 0.52 & 239 & 13.0 & 50.57 & $5.55 \mathrm{E}-05$ \\
146 & 0.09 & 0.67 & 239 & 16.0 & 40.49 & $5.55 \mathrm{E}-05$ \\
146 & 0.09 & 0.61 & 239 & 18.0 & 37.47 & $5.55 \mathrm{E}-05$ \\
\hline
\end{tabular}

\begin{tabular}{ccc} 
& & \\
& $3.70 \mathrm{E}-09$ & $-4.37 \mathrm{E}-08$ \\
& $1.82 \mathrm{E}-09$ & $4.44 \mathrm{E}-08$ \\
& $1.98 \mathrm{E}-09$ & $4.41 \mathrm{E}-08$ \\
& $1.49 \mathrm{E}-09$ & $-3.25 \mathrm{E}-09$ \\
$\mathrm{ND}$ & $1.35 \mathrm{E}-09$ & $7.57 \mathrm{E}-09$ \\
& $1.32 \mathrm{E}-09$ & $2.58 \mathrm{E}-08$ \\
& $9.28 \mathrm{E}-10$ & $2.72 \mathrm{E}-08$ \\
& $1.27 \mathrm{E}-09$ & $2.89 \mathrm{E}-09$ \\
$1.08 \mathrm{E}-09$ & $9.21 \mathrm{E}-09$ \\
& $7.36 \mathrm{E}-10$ & $2.01 \mathrm{E}-08$ \\
$8.82 \mathrm{E}-10$ & $-1.05 \mathrm{E}-08$ \\
\hline
\end{tabular}

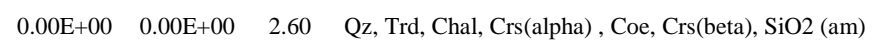
3.33E-04 -3.94E-03 2.60 Qz, Trd, Chal, Crs(alpha), Coe, Crs(beta), SiO2 (am) $4.81 \mathrm{E}-04 \quad-3.25 \mathrm{E}-04 \quad 2.60 \quad$ Qz, Trd, Chal, Crs(alpha), Coe, Crs(beta), SiO2 (am) 8.18E-04 7.18E-03 2.60 Qz, Trd, Chal, Crs(alpha), Coe, Crs(beta), SiO2 (am) $9.46 \mathrm{E}-04 \quad 6.90 \mathrm{E}-03 \quad 2.60 \quad$ Qz, Trd, Chal, Crs(alpha), Coe, Crs(beta), $\mathrm{SiO} 2(\mathrm{am})$ $\begin{array}{llll}9.46 \mathrm{E}-04 & 6.90 \mathrm{E}-03 & 2.60 & \text { Qz, Trd, Chal, Crs(alpha), Coe, Crs(beta), } \mathrm{SiO} 2(\mathrm{am}) \\ 1.06 \mathrm{E}-03 & 7.53 \mathrm{E}-03 & 2.60 & \text { Qz, Trd, Chal, Crs(alpha), Coe, Crs(beta), } \mathrm{SiO} 2 \text { (am) }\end{array}$ 1.18E-03 9.91E-03 2.60 Qz, Trd, Chal, Crs(alpha), Coe, Crs(beta), SiO2 (am) $1.25 \mathrm{E}-03 \quad 1.21 \mathrm{E}-02 \quad 2.60 \quad$ Qz, Trd, Chal, Crs(alpha), Coe, Crs(beta), SiO2 (am) $1.60 \mathrm{E}-03 \quad 1.28 \mathrm{E}-02 \quad 2.60 \quad$ Qz, Trd, Chal, Crs(alpha), Coe, Crs(beta), SiO2 (am) $1.78 \mathrm{E}-03 \quad 1.44 \mathrm{E}-02 \quad 2.60 \quad$ Qz, Trd, Chal, Crs(alpha), Coe, Crs(beta), SiO2 (am) 1.97E-03 1.96E-02 2.60 Qz, Trd, Chal, Crs(alpha), Coe, Crs(beta), SiO2 (am) 2.13E-03 1.77E-02 2.60 Qz, Trd, Chal, Crs(alpha), Coe, Crs(beta), $\mathrm{SiO} 2$ (am)

\begin{tabular}{|c|c|c|c|c|c|c|c|c|c|c|c|c|c|c|}
\hline \multicolumn{15}{|c|}{$" 80-2.5-\mathrm{SiO}-10 \overline{1} ": \mathrm{T}=80^{\circ} \mathrm{C}, \mathrm{pH}=2.5,[\mathrm{SiO}](\mathrm{t}=0)=5.2 \mathrm{E}-3 \mathrm{M},(10 \overline{1})$ orientation, $\Delta \mathrm{Gr}$ (final) $=-$} \\
\hline $\left.\begin{array}{c}\mathbf{S i} \\
{[\mathbf{p p m}]}\end{array}\right]$ & $\left.\begin{array}{c}\mathbf{A l} \\
{[\mathrm{ppm}]}\end{array}\right]$ & $\begin{array}{c}\text { Ca } \\
{[\text { ppm] }}\end{array}$ & $\left.\begin{array}{c}\mathrm{Na} \\
{[\mathrm{ppm}]}\end{array}\right]$ & $\begin{array}{c}\text { time } \\
\text { [days] }\end{array}$ & $\begin{array}{c}\text { Fluid mass } \\
{[\mathrm{g}]}\end{array}$ & $\begin{array}{c}\text { Surface } \\
{\left[\mathbf{m}^{2}\right]}\end{array}$ & $\begin{array}{c}\text { Rate }(\mathbf{S i}) \\
{\left[\mathrm{mol} / \mathbf{m}^{2} / \mathrm{s}\right]}\end{array}$ & $\begin{array}{c}\text { Rate (AI) } \\
{\left[\mathrm{mol} / \mathrm{m}^{2} / \mathrm{s}\right]}\end{array}$ & $\begin{array}{l}\text { Rate }(\mathrm{Ca}) \\
{\left[\mathrm{mol} / \mathrm{m}^{2} / \mathrm{s}\right]}\end{array}$ & $\begin{array}{l}\text { Rate }(\mathrm{Na}) \\
{\left[\mathrm{mol} / \mathrm{m}^{2} / \mathrm{s}\right]}\end{array}$ & $\begin{array}{c}\zeta(\mathbf{A l}) \\
{\left[\mathbf{m o l} / \mathbf{m}^{2}\right]}\end{array}$ & $\begin{array}{c}\zeta(\mathbf{C a}) \\
{\left[\mathrm{mol} / \mathbf{m}^{2}\right]}\end{array}$ & $\begin{array}{c}\mathbf{p H} \\
\text { (sim.) }\end{array}$ & $\begin{array}{l}\text { Phases } \\
\text { with SI>0 }\end{array}$ \\
\hline $146 *$ & 0.02 & $0.23 * *$ & $239 *$ & 0.0 & 103.07 & $2.12 \mathrm{E}-05$ & \multirow{12}{*}{$\mathrm{ND}$} & & & \multirow{12}{*}{ ND } & $0.00 \mathrm{E}+00$ & $0.00 \mathrm{E}+00$ & 2.57 & Qz, Trd, Chal, Crs(alpha), Coe, Crs(beta), SiO2 (am) \\
\hline 146 & 0.02 & 0.17 & 239 & 1.0 & 91.61 & $2.12 \mathrm{E}-05$ & & $6.07 \mathrm{E}-09$ & $-1.33 \mathrm{E}-07$ & & $5.46 \mathrm{E}-04$ & $-1.20 \mathrm{E}-02$ & 2.57 & Qz, Trd, Chal, Crs(alpha), Coe, Crs(beta), $\mathrm{SiO} 2$ (am) \\
\hline 146 & 0.03 & 0.10 & 239 & 2.0 & 86.71 & $2.12 \mathrm{E}-05$ & & 3.50E-09 & $-1.82 \mathrm{E}-07$ & & $8.31 \mathrm{E}-04$ & $-2.67 \mathrm{E}-02$ & 2.57 & Qz, Trd, Chal, Crs(alpha), Coe, Crs(beta), $\mathrm{SiO} 2$ (am) \\
\hline 146 & 0.04 & 0.12 & 239 & 4.0 & 77.67 & $2.12 \mathrm{E}-05$ & & $5.91 \mathrm{E}-09$ & $2.69 \mathrm{E}-08$ & & $1.84 \mathrm{E}-03$ & $-2.22 \mathrm{E}-02$ & 2.57 & Qz, Trd, Chal, Crs(alpha), Coe, Crs(beta), $\mathrm{SiO}$ (am) \\
\hline 146 & 0.04 & 0.15 & 239 & 4.9 & 73.03 & $2.12 \mathrm{E}-05$ & & $5.50 \mathrm{E}-09$ & $4.66 \mathrm{E}-08$ & & $2.31 \mathrm{E}-03$ & $-1.82 \mathrm{E}-02$ & 2.57 & Qz, Trd, Chal, Crs(alpha), Coe, Crs(beta), $\mathrm{SiO}$ (am) \\
\hline 146 & 0.05 & 0.13 & 239 & 5.9 & 68.28 & 2.12E-05 & & $6.49 \mathrm{E}-09$ & $-2.87 \mathrm{E}-08$ & & $2.85 \mathrm{E}-03$ & $-2.06 \mathrm{E}-02$ & 2.57 & Qz, Trd, Chal, Crs(alpha), Coe, Crs(beta), $\mathrm{SiO} 2$ (am) \\
\hline 146 & 0.06 & 0.23 & 239 & 7.0 & 58.92 & $2.12 \mathrm{E}-05$ & & $6.28 \mathrm{E}-09$ & $1.39 \mathrm{E}-07$ & & 3.43E-03 & $-7.71 \mathrm{E}-03$ & 2.57 & Qz, Trd, Chal, Crs(alpha), Coe, Crs(beta), $\mathrm{SiO} 2$ (am) \\
\hline 146 & 0.06 & 0.25 & 239 & 7.9 & 54.28 & 2.12E-05 & & 4.62E-09 & 3.52E-08 & & 3.79E-03 & $-4.93 \mathrm{E}-03$ & 2.57 & Qz, Trd, Chal, Crs(alpha), Coe, Crs(beta), $\mathrm{SiO} 2(\mathrm{am})$ \\
\hline 146 & 0.10 & 0.22 & 239 & 11.1 & 49.47 & 2.12E-05 & & $6.74 \mathrm{E}-09$ & $-1.44 \mathrm{E}-08$ & & $5.64 \mathrm{E}-03$ & $-8.87 \mathrm{E}-03$ & 2.57 & Qz, Trd, Chal, Crs(alpha), Coe, Crs(beta), $\mathrm{SiO}$ (am) \\
\hline 146 & 0.12 & 0.19 & 239 & 13.0 & 44.43 & 2.12E-05 & & 7.15E-09 & $-1.83 \mathrm{E}-08$ & & $6.83 \mathrm{E}-03$ & $-1.19 \mathrm{E}-02$ & 2.57 & Qz, Trd, Chal, Crs(alpha), Coe, Crs(beta), SiO2 (am) \\
\hline 146 & 0.16 & 0.26 & 239 & 16.0 & 35.35 & $2.12 \mathrm{E}-05$ & & 7.02E-09 & $2.17 \mathrm{E}-08$ & & 8.64E-03 & $-6.30 \mathrm{E}-03$ & 2.57 & Qz, Trd, Chal, Crs(alpha), Coe, Crs(beta), $\mathrm{SiO} 2$ (am) \\
\hline 146 & 0.20 & 0.24 & 239 & 18.0 & 31.73 & $2.12 \mathrm{E}-05$ & & $8.09 \mathrm{E}-09$ & $-8.39 \mathrm{E}-09$ & & $1.01 \mathrm{E}-02$ & $-7.79 \mathrm{E}-03$ & 2.57 & Qz, Trd, Chal, Crs(alpha), Coe, Crs(beta), $\mathrm{SiO} 2$ (am) \\
\hline \multicolumn{15}{|c|}{ "80-3-SiO2-1": $\mathrm{T}=80^{\circ} \mathrm{C}, \mathrm{pH}=3,[\mathrm{SiO} 2](\mathrm{t}=0)=5.2 \mathrm{E}-3 \mathrm{M}$, multiple orientations experiment, $\Delta \mathrm{Gr}(\mathrm{final})=-58.68 \mathrm{~kJ} / \mathrm{mol}$} \\
\hline $\begin{array}{c}\mathbf{S i} \\
{[\mathrm{ppm}]}\end{array}$ & $\begin{array}{c}\mathbf{A l} \\
{[\mathrm{ppm}]}\end{array}$ & $\begin{array}{c}\mathrm{Ca} \\
{[\mathrm{ppm}]}\end{array}$ & $\begin{array}{c}\mathrm{Na} \\
{[\mathrm{ppm}]}\end{array}$ & $\begin{array}{c}\text { time } \\
\text { [days] }\end{array}$ & $\begin{array}{c}\text { Fluid mass } \\
{[\mathrm{g}]}\end{array}$ & $\begin{array}{c}\text { Surface } \\
{\left[\mathrm{m}^{2}\right]}\end{array}$ & $\begin{array}{c}\text { Rate }(\mathbf{S i}) \\
{\left[\mathrm{mol} / \mathbf{m}^{2} / \mathrm{s}\right]}\end{array}$ & $\begin{array}{c}\text { Rate (Al) } \\
{\left[\mathrm{mol} / \mathrm{m}^{2} / \mathrm{s}\right]}\end{array}$ & $\begin{array}{l}\text { Rate }(\mathrm{Ca}) \\
{\left[\mathrm{mol} / \mathrm{m}^{2} / \mathrm{s}\right]}\end{array}$ & $\begin{array}{l}\text { Rate }(\mathrm{Na}) \\
{\left[\mathrm{mol} / \mathrm{m}^{2} / \mathrm{s}\right]}\end{array}$ & $\begin{array}{c}\zeta(\mathbf{A l}) \\
{\left[\mathbf{m o l} / \mathbf{m}^{2}\right]}\end{array}$ & $\begin{array}{c}\zeta(\mathbf{C a}) \\
{\left[\mathrm{mol} / \mathrm{m}^{2}\right]}\end{array}$ & $\begin{array}{c}\mathrm{pH} \\
\text { (sim.) }\end{array}$ & $\begin{array}{l}\text { Phases } \\
\text { with SI>0 }\end{array}$ \\
\hline $146^{*}$ & 0.02 & 0.05 & $239^{*}$ & 0.0 & 109.53 & $3.00 \mathrm{E}-04$ & \multirow{7}{*}{ ND } & & & \multirow{7}{*}{ ND } & $0.00 \mathrm{E}+00$ & $0.00 \mathrm{E}+00$ & 3.00 & Qz, Trd, Chal, Crs(alpha), Coe, Crs(beta), SiO2 (am) \\
\hline 147 & 0.21 & 0.20 & 239 & 4.0 & 105.82 & 3.00E-04 & & 4.72E-09 & $7.26 \mathrm{E}-09$ & & $1.63 \mathrm{E}-03$ & $2.51 \mathrm{E}-03$ & 3.00 & Qz, Trd, Prl, Chal, Crs(alpha), Coe, Crs(beta), $\mathrm{SiO} 2$ (am) \\
\hline 147 & 0.37 & 0.28 & 239 & 10.0 & 102.11 & 3.00E-04 & & $2.55 \mathrm{E}-09$ & $2.55 \mathrm{E}-09$ & & 2.95E-03 & 3.83E-03 & 3.01 & Prl, Qz, Trd, Chal, Crs(alpha), Kln, Bei-H, Coe, Crs(beta), SiO2 (am) \\
\hline 147 & 0.47 & 0.35 & 239 & 14.0 & 98.40 & $3.00 \mathrm{E}-04$ & & $2.35 \mathrm{E}-09$ & $3.07 \mathrm{E}-09$ & & $3.77 \mathrm{E}-03$ & $4.89 \mathrm{E}-03$ & 3.02 & Prl, Qz, Trd, Chal, Crs(alpha), Kln, Bei-H, Coe, Crs(beta), SiO2 (am), Bei-Ca, Bei-Na \\
\hline 147 & 0.54 & 0.39 & 239 & 18.0 & 94.69 & $3.00 \mathrm{E}-04$ & & $1.71 \mathrm{E}-09$ & $1.77 \mathrm{E}-09$ & & 4.36E-03 & $5.50 \mathrm{E}-03$ & 3.03 & Prl, Qz, Trd, Chal, Crs(alpha), Kln, Bei-H, Coe, Crs(beta), SiO2 (am), Bei-Ca, Bei-Na \\
\hline 147 & 0.64 & 0.44 & 239 & 21.0 & 90.74 & 3.00E-04 & & $2.86 \mathrm{E}-09$ & 3.02E-09 & & $5.10 \mathrm{E}-03$ & $6.28 \mathrm{E}-03$ & 3.04 & Prl, Qz, Trd, Chal, Crs(alpha), Kln, Bei-H, Coe, Crs(beta), SiO2 (am), Bei-Ca, Bei-Na \\
\hline 148 & 0.75 & 0.50 & 239 & 27.0 & 86.82 & $3.00 \mathrm{E}-04$ & & $1.46 \mathrm{E}-09$ & $1.44 \mathrm{E}-09$ & & $5.86 \mathrm{E}-03$ & 7.03E-03 & 3.04 & Prl, Qz, Trd, Chal, Crs(alpha), Kln, Bei-H, Coe, Crs(beta), SiO2 (am), Bei-Ca, Bei-Na \\
\hline
\end{tabular}

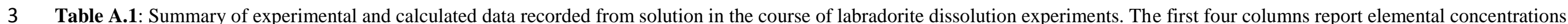

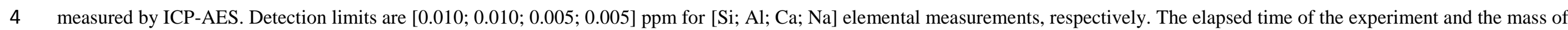

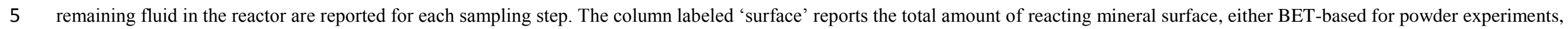

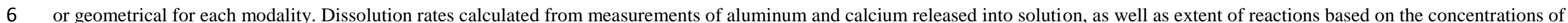

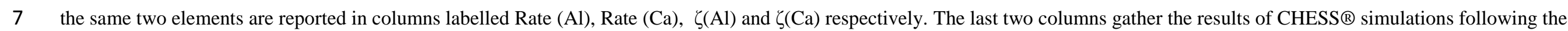


8 methodology presented in section 2.3, that is, the simulated $\mathrm{pH}$ and the phases with respect to which the fluid was supersaturated (SI>0). These phases were abbreviated as follows: Bei- $\mathrm{H}=$

9 Beidellite-H, Bei-Ca $=$ Beidellite-Ca, Bei-Na $=$ Beidellite-Na, Bhm $=$ Boehmite, Chal $=$ Chalcedony, Coe $=$ Coesite, $\operatorname{Crn}=\operatorname{Corundum}, \operatorname{Crs}(\alpha)=\operatorname{Cristobalite}-\alpha, \operatorname{Crs}(\beta)=\operatorname{Cristobalite}-\beta$, Dsp $=$

10 Diaspore, Gbs = Gibbsite, $\mathrm{Kln}=$ Kaolinite, $\mathrm{Prl}=$ Pyrophillite, $\mathrm{Qz}=\mathrm{Quartz}, \mathrm{SiO}_{2}(\mathrm{am})=$ amorphous silica, $\mathrm{Trd}=$ Tridymite. For each experiment, final value for Gibbs free energy

11 corresponding to labradorite dissolution at $80^{\circ} \mathrm{C}\left(\Delta G_{r}^{L a b}\right)$ is indicated.

$12 *$ Calculated from Ca when available, on Al elsewhere, under stoichiometric release assumption (see paragraph 2.3).

$13 * *$ Ca data with low signal/noise ratios. Dissolution rates calculated from these data were consequently affected and not taken into account in the interpretation. 